Nayara Izabel Viana

\title{
O papel dos micro RNAs 143 e 145 e seus genes alvo na etiopatogenia da hiperplasia prostática benigna
}

Dissertação apresentada à Faculdade de Medicina da Universidade de São Paulo para obtenção do título de Mestre em Ciências

Programa de Urologia

Orientador: Prof. Dr. Alberto Azoubel Antunes

São Paulo 


\section{Dados Internacionais de Catalogação na Publicação (CIP)}

Preparada pela Biblioteca da

Faculdade de Medicina da Universidade de São Paulo

@reprodução autorizada pelo autor

Viana, Nayara Izabel

O papel dos micro RNAs 143 e 145 e seus genes alvo na etiopatogenia da hiperplasia prostática benigna / Nayara Izabel Viana. -- São Paulo, 2012.

Dissertação(mestrado)--Faculdade de Medicina da Universidade de São Paulo. Programa de Urologia.

Orientador: Alberto Azoubel Antunes.

Descritores: 1.Hiperplasia prostática/etiologia 2.MicroRNAs 3.Perfil da express̃o gênica 4.Reação em cadeia da polimerase em tempo real 5 .Western blotting

USP/FMDBD-385/12 
"Aos meus pais Antônio e Rozilane e a minha avó Ceci pelo amor incondicional e pelo incentivo a todos os meus sonhos" 


\section{Agradecimentos}

A Deus, pelo dom da vida, pela proteção e pelas bênçãos que me concede todos os dias.

Ao Prof. Dr. Alberto Azoubel Antunes, meu orientador, por ter me aceitado como sua aluna, pelo empenho e dedicação ao meu trabalho e pelo carinho que sempre teve em me ajudar em todos os momentos. Muito obrigada por ter me dado a honra de tê-lo como orientador.

À Prof. Dra. Katia Ramos Moreira Leite, pelo carinho com que me recebeu e pela oportunidade de aprender ao seu lado. Muito obrigada por todas as oportunidades que tem me dado e principalmente, pela sua incansável boa vontade em nos ensinar que podemos fazer muito mais e melhor do que achamos que somos capazes.

À minha querida amiga Dra. Sabrina Thalita dos Reis, a grande responsável pela realização deste sonho. Obrigada pela confiança que depositou em mim e por tudo que me ajudou a conquistar até aqui. Seu amor de irmã, que me acolheu em sua família, foi fundamental para que eu me sentisse muito feliz aqui. Obrigada amiga, você mora no meu coração.

Ao Prof. Dr. Miguel Srougi, pelo incentivo, atenção e carinho que tem com o nosso laboratório. Obrigada pelo exemplo que nos dá, de humildade e amor ao próximo.

Ao Dr. Nelson Dip, um grande amigo por quem tenho imensa admiração. Obrigada pela sua ajuda neste trabalho, pela sua amizade, apoio e por nos presentear com sua inteligência e sua alegria.

A todos os meus amigos do LIM-55, por toda ajuda e pela amizade que construímos. Todos vocês são muito especiais pra mim e é uma honra trabalhar com vocês: Iran Amorim Silva, Michele Silva, Caio Martins Moura, Denis Reis Morais, Dra. Camila Belfort Piantino, Dr. Manuel Garcia Florez, Dr. José Pontes Junior, Betina Katz, Luciana Sevo e Vanessa Guimarães.

Ao Prof. Dr. Homero Bruschini, pelo empenho em conduzir da melhor forma o programa de Pós-Graduação da Disciplina de Urologia. 
Às secretárias da Urologia, Elisa, Iones, Inisabete,Teresa e Aparecida, pela boa vontade e alegria que sempre têm ao nos ajudar da melhor forma possível.

Aos meus pais, Antônio e Rozilane, por esse amor incondicional que nos une e que só cresce a cada dia. Vocês são as pessoas mais maravilhosas que conheço e eu só tenho a agradecer a Deus por ter me abençoado em ter vocês como pais. Obrigada pela criação que me deram, pelos valores que me ensinaram e por nunca medirem esforços pra realizar os meus sonhos. Amo muito vocês.

Ao meu avô José Malta, que se entristece pela minha distância, mas que se alegra por minhas conquistas e torce pela minha felicidade. Aos meus avós, José Afonso e Izabel que hoje não estão mais entre nós, mas que me dedicaram tanto amor e com certeza hoje se alegram muito por mim. À minha avó Ceci, minha segunda mãe, que também não está mais entre nós. Seu amor estará sempre comigo e nunca poderei agradecer tudo que fez por mim.

Ao meu noivo, Carlos Eduardo, que trouxe tanto amor a minha vida. Obrigada meu amor, por todo apoio, dedicação, carinho e por compartilhar com tanta generosidade todos os meus sonhos. Você é muito especial e ter você ao meu lado é uma grande alegria. Amo você.

Aos meus tios, Paulo, João Pedro, Antônio Ambrósio e Roberval, às minhas tias Maria José, Vera e Silvania e às minhas madrinhas Rosângela e Luciana, pelo amor, pelo apoio e pelas orações. Vocês são pessoas muito especiais na minha vida, com as quais sei que posso contar em todos os momentos.

Aos meus primos e primas, Paula, Marcos, Otávio e Carolyna, por serem meus irmãos de coração, pelo amor que têm por mim e por sempre trazerem alegria a minha vida.

Às minhas amadas amigas, Valéria, Luz Maria, Nyara, Taíla, Thaysa, Karen, Patrícia, Cleo e Bruna, pela torcida e incentivo e pelo carinho em cultivar nossa amizade, apesar da distância. 
Ao meu amigo Leandro Faria, que juntamente com sua esposa Sabrina, me acolheram e me ajudaram em tudo que foi possível. Agradeço também ao Sr. Geraldo e Neuza Reis, pelo carinho que sempre têm comigo. 
Esta dissertação está de acordo com as seguintes normas, em vigor no momento desta publicação:

Referências: adaptado de International Committe of Medical Journals Editors (Vancouver).

Universidade de São Paulo. Faculdade de Medicina. Divisão de Biblioteca e Documentação. Guia de apresentação de dissertações, teses e monografias. Elaborado por Anneliese Carneiro da Cunha, Maria Julia de A. L. Freddi, Maria F. Crestana, Marinalva de Souza Aragão, Suely Campos Cardoso, Valéria Vilhena. $3^{a}$ ed. São Paulo: Serviço de Biblioteca e Documentação; 2011.

Abreviaturas dos títulos dos periódicos de acordo com List of Journals Indexed in Index Medicus. 


\section{Sumário}

Lista de abreviaturas, símbolos e siglas

Lista de Figuras

Lista de Tabelas

Resumo

Summary

1. Introdução

1.1 Hiperplasia Prostática Benigna ___ 2

1.2 Aspectos Fisiopatológicos __ 3

1.3 Etiopatogenia da Hiperplasia Prostática Benigna___ 4

1.3.1 Fatores de risco em HPB__ 5

1.3.2 Influência dos andrógenos e dos fatores de crescimento ___ 6

$\begin{array}{lll}\text { 1.3.3 Papel dos estrógenos___ } & 8\end{array}$

1.3.4 Inflamação e reação imunológica local___ 8

1.4 Manifestações Clínicas___ 9

1.5 Diagnóstico___ 9

$\begin{array}{ll}1.6 \text { Tratamento } & 10\end{array}$

$\begin{array}{ll}1.7 \text { Biologia Molecular da HPB } & 10\end{array}$

$\begin{array}{ll}1.8 \text { Micro RNA } & 13\end{array}$

$\begin{array}{ll}\text { 1.8.1 Biogênese dos miRNAs___ } & 14\end{array}$

$\begin{array}{ll}\text { 1.8.2 Funções dos miRNAs___ } & 16\end{array}$

$\begin{array}{lr}1.9 \text { Justificativa__ } & 17\end{array}$

$\begin{array}{lr}\text { 2. Objetivos__ } & 19\end{array}$ 
3. Métodos

3.1 Tipo do Estudo

3.2 Pacientes

3.2.1 Critérios de Inclusão

3.2.2 Critérios de Exclusão

3.3 Ética

24

3.4 Processamento das Amostras

25

3.5 Isolamento do miRNA, do RNA e Síntese do cDNA

25

3.5.1 Isolamento do miRNA e do RNA dos espécimes cirúrgicos

3.5.2 Síntese do DNA complementar

3.6 Análise da Expressão de miRNA e RNA

28

3.7 Western Blotting

3.8 Análise estatística

4. Resultados

4.1 Padrão de Expressão dos miRNAs e seus Genes Alvo

4.2 Expressão dos miRNAs e seus Genes Alvo e os níveis de PSA pré-operatório

4.3 Expressão dos miRNAs e seus Genes Alvo e o Uso de Cateter Vesical

4.4 Expressão dos miRNAs e seus Genes Alvo e o Peso da Próstata na Ultrassonografia

42

4.5 Expressão dos miRNAs e seus Genes Alvo e a Idade

4.6 Expressão Proteica

44

4.7 Expressão das Proteínas e os Parâmetros Clínicos dos Pacientes 
com HPB

5. Discussão

51

5.1 Perspectivas

6. Conclusões 64

7. Anexos 66

8. Referências Bibliográficas 73 Apêndices 


\section{Lista de abreviaturas, símbolos e siglas}

ACE - Enzima de conversão da angiotensina

AGT1R - Receptor de angiotensina tipo 1

BMP5 - Bone morphogenetic protein 5

BSA - Albumina de soro bovino

B2M - $\beta 2$-microglobulina

CaP - Carcinoma prostático

cDNA - DNA complementar

COX2 - Ciclo-oxigenase 2

DHT - Di-hidrotestosterona

EGF - Fator de crescimento epitelial

$E R \alpha$ - Receptores estrogênicos alfa

ERK5 - Extracellular-Signal-Regulated Kinase 5

ESTs - Expressed sequence tag

FGF - Fator de crescimento de fibroblastos

GSTM5 - Glutathione S-transferase mu 5

HPB - Hiperplasia Prostática Benigna

IGF - Fator similar à insulina

KGF - Fator de crescimento de queratinócitos

KRAS - V-Ki-ras2 Kirsten Rat Sarcoma Viral Oncogene Homolog

LH - Hormônio luteinizante

LUTS - Sintomas do trato urinário inferior

MAPK - Mitogen-Activated Protein Kinase

MAP3K3 - Mitogen-Activated Protein Kinase Kinase Kinase 3

MAP4K4 - Mitogen-Activated Protein Kinase Kinase Kinase Kinase 4 
miRNA - microRNA

MMP2 - Metaloproteinase da matriz 2

mTOR - Mammalian target of rapamycin

NGF - Nerve growth factor

ORFs - Open reading frame

pri-miRNA - microRNA primário

PSA - Antígeno específico da próstata

PVDF - Fluoreto de polivinilideno

qRT-PCR - Reação em cadeia da polimerase em tempo real quantitativa

RISC - Complexo silenciador induzido por RNA

RNA - Ácido ribonucleico

RNAm - RNA mensageiro

RUA - Retenção urinária aguda

SRD5A2 - Steroid-5-alpha-reductase

TBS-T - Tampão tris salino Tween 20

TGF- $\beta 3$ - Transforming growth factor beta 3

USG - ultrassonografia

WB - Western Blotting 


\section{Lista de Figuras}

Figura 1 - Representação esquemática da biogênese e ação supressora pós-transcripcional dos miRNA

Figura 2 - miR-145 e seus genes alvo MAP4K4 e MAP3K3 e miR-143 e seus genes alvo KRAS e ERK5

Figura 3 - Esquematização da reação de síntese do DNA complementar a partir do $\mathrm{RNA}(\mathrm{A})$ e do miRNA(B) isolados do tecido

Figura 4 - Esquema de amplificação pela técnica de PCR em tempo real quantitativo (qRT-PCR)

Figura 5 - Curva de calibração de concentração de proteínas

Figura 6 - Perfil de expressão do miR-143 e dos genes ERK5 e KRAS em 44 pacientes com HPB

Figura 7 - Perfil de expressão do miR-145 e dos genes MAP3K3 e MAP4K4 em 44 pacientes com HPB

Figura 8 - Imagem digital da reação de Western Blotting representando a presença da proteína KRAS em amostras de HPB

Figura 9 - Imagem digital da reação de Western Blotting representando a presença da proteína MAP3K3 em amostras de HPB

Figura 10 - Imagem digital da reação de Western Blotting representando maior ausência da proteína ERK5 em amostras de HPB

Figura 11 - Imagem digital da reação de Western Blotting representando a ausência da proteína MAP4K4 em amostras de HPB

Figura 12 - Imagem digital da reação de Western Blotting representando 


\section{Lista de Tabelas}

Tabela 1 - Características demográficas dos 44 pacientes submetidos a tratamento cirúrgico para HPB

Tabela 2 - miRNA estudados por qRT-PCR e seus genes alvo

Tabela 3 - Primers utilizados para quantificação da expressão dos miRNAs 143 e 145 e seus genes alvo na HPB

Tabela 4 - Anticorpos utilizados para detecção da expressão proteica

Tabela 5 - Média de expressão dos miRNAs e genes estudados nos 44 pacientes com HPB comparados com o controle normal

Tabela 6 - Expressão dos miR-143 e 145 e seus genes alvo de acordo com o valor do PSA pré-operatório

Tabela 7 - Expressão dos miR-143 e 145 e seus genes alvo de acordo com o uso de cateter vesical

Tabela 8 - Expressão dos miR-143 e 145 e seus genes alvo de acordo com o peso da próstata na ultrassonografia

Tabela 9 - Expressão dos miR-143 e 145 e seus genes alvo de acordo com a idade

Tabela 10 - Média de expressão e porcentagem de presença e ausência por Western Blotting das proteínas ERK5, KRAS, MAP3K3, MAP4K4 e $\beta$ actina estudadas em 38 pacientes com HPB

Tabela 11 - Expressão das proteínas de acordo com o PSA préoperatório

Tabela 12 - Expressão das proteínas de acordo com o uso do cateter 
vesical

Tabela 13 - Expressão das proteínas de acordo com o peso da próstata na ultrassonografia

Tabela 14 - Expressão das proteínas de acordo com a idade 


\section{RESUMO}

Viana NI. O papel dos micro RNAs 143 e 145 e seus genes alvo na etiopatogenia da hiperplasia prostática benigna [dissertação]. São Paulo: Faculdade de Medicina, Universidade de São Paulo; 2012.

Introdução: A hiperplasia prostática benigna (HPB) é apontada como um dos mais comuns problemas de saúde associado ao envelhecimento dos homens. A incidência da doença começa a aumentar a partir dos 40 anos de idade, e se torna frequente em cerca de $50 \%$ dos homens com 50 anos e em quase $90 \%$ dos homens após a oitava década. A etiopatogenia da HPB ainda não foi totalmente elucidada, mas sabe-se que alguns fatores aumentam os riscos de aparecimento do problema. Seu melhor entendimento contribuiria substancialmente para o estabelecimento de um consenso terapêutico para a doença. Nesse sentido, os marcadores moleculares têm sido pesquisados na tentativa de auxiliar ou mesmo suplantar a eficiência dos métodos tradicionais. MicroRNAs (miRNAs) são uma classe de pequenos RNA regulatórios (19-25 nucleotídeos), não codificadores que possuem um papel fundamental no controle da expressão gênica. Essas pequenas moléculas estão envolvidas em vários processos celulares fisiológicos e patológicos. Alguns estudos demonstraram que os miRNAs 143 e 145 têm papel fundamental na diferenciação e proliferação celular da musculatura lisa. A ação de miRNAs na HPB ainda foi pouco explorada. Objetivos: Analisar a expressão do miR-143 e de seus genes e proteínas alvo ERK5 e KRAS e do miR-145 e dos seus genes e proteínas alvo MAP3K3 e MAP4K4, em pacientes portadores de HPB e comparar os perfis de expressão destes com parâmetros clínicos dos pacientes. Material e Métodos: Para análise dos miRNAs e dos seus genes alvo, foram estudados 44 pacientes diagnosticados com HPB submetidos à ressecção transuretral da próstata ou prostatectomia aberta. A análise da expressão foi realizada pela técnica de RT-PCR quantitativo. O grupo controle foi composto de tecido prostático normal de dois pacientes jovens doadores de órgãos. A análise proteica foi feita a partir de 38 pacientes, pela técnica de Western Blotting. Resultados: Os miRNA 143 e 145, apresentaram superexpressão em $62,5 \%$ e $73,8 \%$ dos casos, respectivamente. $O$ gene ERK5 apresentou subexpressão de 59,4\%, evidenciando um possível controle negativo por parte do miR-143. O gene MAP4K4 apresentou subexpressão na totalidade das amostras estudadas, demonstrando um possível controle por parte do miR-145. Os genes KRAS e MAP3K3 apresentaram superexpressão de $79,4 \%$ e $61,5 \%$ das amostras, respectivamente. De acordo com a expressão proteica, encontramos perfis semelhantes aos da expressão gênica. Foi encontrada maior expressão das proteínas KRAS e MAP3K3. Considerando a expressão gênica e proteica comparadas aos parâmetros clínicos, somente a proteína ERK5 apresentou significância $(p=0,019)$, estando mais presente em pacientes com próstatas > 60 gramas. Conclusão: A superexpressão dos miRNAs 143 e 145 encontrada neste estudo pode estar envolvida na etiopatogenia da HPB alterando a homeostase do tecido fibromuscular principalmente, controlando proliferação e diferenciação. A superexpressão gênica e a forte expressão 
proteica de KRAS também pode estar envolvida na etiopatogenia da HPB, já que esta molécula quando ativada é responsável pelo estímulo de vias que resultam na proliferação, sobrevivência, motilidade celular e tráfego intracelular. A superexpressão do MAP3K3 pode estar sendo responsável pela angiogênese que ocorre em HPB. A subexpressão de MAP4K4, neste caso possivelmente controlada por miR-145, pode estar deixando de regular negativamente mTOR, gerando uma proliferação celular irregular responsável pela HPB. A detecção das proteínas em níveis semelhantes aos que foram encontrados na expressão gênica reforça estas hipóteses.

Descritores: Hiperplasia Prostática/etiologia; Micro RNAs; Perfil da expressão gênica; Reação em cadeia da polimerase em tempo real, Western Blotting 


\section{SUMMARY}

Viana NI. The role of micro RNAs 143 and 145 and their target genes in the etiopathogenesis of benign prostatic hyperplasia [dissertation]. Sao Paulo: "Faculdade de Medicina, Universidade de São Paulo"; 2012.

Introduction: Benign prostatic hyperplasia (BPH) is one of the most common male health problems associated with aging. The incidence of disease starts to increase after 40 years, and compromises half of men in the fifths and almost $90 \%$ over 80 years. The pathogenesis of BPH has not been fully elucidated, but it is known that some factors increase the risk of occurrence of the problem. A better understanding of BPH pathogenesis would substantially contribute to the establishment of a therapeutic consensus for the disease. Thus, molecular markers have been investigated attempting to help or even overcome the efficiency of traditional methods. MicroRNAs (miRNAs) are a class of small non-coding regulatory RNA (19-25 nucleotides) that plays a key role in gene expression control. These small molecules are involved in various physiological and pathological cellular processes. Some studies have shown that miRNAs 143 and 145 play a fundamental role in cellular differentiation and proliferation of smooth muscles. The action of miRNAs in BPH has been poorly explored. Objectives: Analyze the expression of miR-143 and its target genes and proteins ERK5 and KRAS and miR-145 and its target genes and proteins MAP3K3 and MAP4K4, in patients with BPH and compare their expression profiles with clinical parameters of patients. Material and Methods: For analysis of miRNAs and its target genes, we studied 44 patients diagnosed with BPH undergoing transurethral resection of the prostate or open prostatectomy. The expression analysis was performed by quantitative RTPCR. Control group consisted of normal prostate tissue from two young patients organ donors. Protein analysis was done from of 38 patients using Western Blotting technique. Results: miR-143 and 145 presented overexpression in $62.5 \%$ and $73.8 \%$ of cases, respectively. The ERK5 gene demonstrated underexpression in $59.4 \%$, indicating a possible control by the miR-143. MAP4K4 gene showed underexpression in $100 \%$ of samples and could be under a potential control by the miR-145. KRAS and MAP3K3 genes revealed overexpression of $79.4 \%$ and $61.5 \%$ of cases, respectively. According protein expression, to find similar profiles of gene expression. We found an increased expression of the proteins MAP3K3 and KRAS. Considering the gene expression and protein compared to clinical parameters, only the protein ERK5 showed significance $(p=0.019)$, being more present in patients with prostates $>60$ grams. Conclusions: Overexpression of miRNAs 143 and 145 found in this work may be involved in the pathogenesis of BPH mainly by changing the fibromuscular tissue homeostasis, controlling proliferation and differentiation. Overexpression of KRAS may also be involved in the pathogenesis of $\mathrm{BPH}$, since this molecule when activated can trigger cell proliferation, survival, intracellular trafficking and motility. Overexpression of MAP3K3 can be responsible for BPH angiogenesis. The MAP4K4 underexpression, in this case possibly controlled 
by miR-145 overexpression, could inhibit mTOR pathway, leading to irregular cell proliferation responsible for disease. Detection of proteins at similar levels to those found in gene expression reinforce our hypothesis.

Descriptors: Benign Prostatic/etiology; Micro RNAs; Gene expression profile; Real time polymerase chain reaction; Western Blotting 
1. INTRODUÇÃO 


\subsection{Hiperplasia Prostática Benigna}

A Hiperplasia Prostática Benigna (HPB) é a condição clínica mais frequente da próstata a partir da sexta década de vida, sendo a neoplasia benigna mais comum nos homens. No Brasil, calcula-se que um em cada dez homens irá desenvolver um quadro histológico de HPB ou um carcinoma prostático (CaP) (Cardoso et al., 2000).

Nos Estados Unidos 14 milhões de homens têm sintomas de HPB e em todo o mundo esse número alcança 30 milhões. Devido ao aumento da expectativa de vida, a HPB tem sido cada vez mais identificada. Em um estudo envolvendo 914 homens com idade média de 61 anos submetidos a um programa de detecção de câncer de próstata no Hospital das Clínicas da Universidade de São Paulo, 48\% deles apresentavam sintomas do trato urinário inferior relacionados à HPB de intensidade moderada à grave (Antunes et al., 2008).

A HPB caracteriza-se por um crescimento tumoral benigno que resulta na hiperplasia do estroma e do tecido glandular, em arranjo nodular (Billis, 1997). Essa condição histológica da próstata é frequentemente associada à obstrução da uretra que se associa a sintomas do trato urinário inferior (LUTS), como, por exemplo, fluxo urinário baixo, hesitação, urgência, esvaziamento vesical incompleto, além de noctúria e desenvolvimento de retenção urinária, que afetam grandemente a qualidade de vida de seus portadores (Franco-Salinas et al., 2010).

Além do sofrimento físico, o crescimento da próstata pode causar problemas sérios com o passar do tempo. A retenção de urina e o aumento 
da pressão intravesical podem ocasionar infecções do trato urinário, retenção urinária aguda (RUA), danos à bexiga ou rins, predispor formação de cálculo vesical (Grosse, 1990), insuficiência renal aguda (Mukamel et al., 1979), incontinência urinária (Uson et al., 1991; Bosch et al., 1994; Wei et al., 2005) e levar a necessidade de exérese cirúrgica da próstata (Glynn et al., 1985). Se a bexiga for permanentemente danificada, o tratamento para a HPB pode ser ineficiente.

A doença causa muito constrangimento entre os pacientes. Tratar a HPB é muito importante para a melhoria da qualidade de vida do homem. À medida que a HPB progride, aumentam potencialmente as situações incômodas e desagradáveis que a doença traz. O paciente com esse distúrbio chega a se levantar três vezes ou mais durante a noite para urinar, o que leva à sonolência e redução da vitalidade, podendo ser responsável por acidentes domésticos, acidentes de trânsito, impactando ainda a produtividade profissional.

\subsection{Aspectos Fisiopatológicos}

A próstata normal apresenta dois componentes, o epitélio glandular arranjado em ácinos e ductos, e o estroma basicamente formado por fibras musculares lisas associadas a tecido conjuntivo, com marcante presença de fibras colágenas, fibras elásticas e fibroblastos, vasos sanguíneos e linfáticos. No entanto, não há uma unanimidade entre os pesquisadores se o principal elemento envolvido no aumento da próstata é de origem epitelial (ductos ou os alvéolos prostáticos) (McNeal, 1978) ou proveniente da 
proliferação de células do estroma (Barstch et al., 1979; Deering et al., 1994).

A gênese histopatológica da HPB tem início com um desequilíbrio molecular progredindo para formação de nódulos hiperplásicos que tendem a aumentar de tamanho. Esse fenômeno afeta a arquitetura histológica da próstata (McNeal, 1997). Esses nódulos circundam a uretra (Franks, 1954; Mostofi et al., 1973) e comprimem as demais regiões (McNeal, 1984; Sampaio, 1992; McNeal, 1997). Eles podem ser formados por numerosos ácinos e ductos, com estroma escasso ("hiperplasia glandular") ou então, são constituídos por tecido do estroma prostático, com deposição de colágeno, proliferação de fibroblastos e de células musculares e com escasso ou nenhum tecido glandular ("hiperplasia do estroma”) (Franks, 1954; Mostofi et al., 1973).

Estudos mostram que quase sempre os dois tipos de crescimento coexistem nos pacientes com HPB. Entre 50 e $61 \%$ do peso das próstatas com HPB, são representados por estroma e apenas 12 a 20\% correspondem a tecido epitelial glandular (Bartsch et al., 1979; Marks et al., 1994).

\subsection{Etiopatogenia da Hiperplasia Prostática Benigna}

A etiopatogenia da HPB ainda não foi totalmente elucidada (De Marzo et al., 1999), mas sabe-se que alguns fatores aumentam os riscos de aparecimento do problema. Apesar da ausência de uma definição mais precisa dessa afecção, algumas teorias complementares têm sido propostas 
(Tang et al., 2009), permitindo caracterizar a ocorrência dos quadros de HPB.

\subsubsection{Fatores de risco em HPB}

HPB é uma doença relacionada ao aumento da idade e à presença dos testículos (Sidney et al., 1991; Juniewicz et al., 1994; Lepor, 2004; Untergasser et al., 2005). A prevalência histológica da doença é de $10 \%$, $50 \%$ e $90 \%$ aos 25, 60 e 80 anos de idade, respectivamente (Lima et al., 2010). Embora suas manifestações clínicas ocorram menos comumente que a HPB histológica, elas avançam com a idade. O estudo de Bianchi-Frias et al. (2010), envolvendo a análise do estroma prostático de animais jovens e velhos identificou uma mudança significativa na expressão de genes relacionados à inflamação e stress oxidativo. $\mathrm{O}$ trabalho demonstrou ainda que, durante o envelhecimento normal, o estroma da próstata apresenta características fenotípicas e moleculares que contribuem para o aparecimento de patologias que afetam a próstata.

Alguns outros fatores como raça (Wilson, 1980; Kristal et al., 2007), consumo de tabaco (Morrison, 1978), cirrose hepática (Akdogan et al., 2002), vasectomia e atividade sexual (Wilson et al., 1980) e hereditariedade (Partin et al., 1994; Sanda et al., 1994) têm sido implicados com a doença.

Recentemente fatores de risco relacionados às doenças cardiovasculares também vêm sendo relacionados à HPB e ao LUTS. Obesidade (Glynn et al., 1985; Wei et al., 2005; Kristal et al., 2007), 
elevação dos índices glicêmicos (Wei et al., 2005; Rohrmann et al., 2005), diabetes (Joseph et al., 2003; Wei et al., 2005; Rohrmann et al., 2005), dislipidemia (Parsons, 2007; Parsons et al., 2008) e síndrome metabólica (Rohrmann et al., 2005; Parsons et al., 2008) podem aumentar significativamente os riscos de HPB e LUTS.

\subsubsection{Influência dos andrógenos e dos fatores de crescimento}

A HPB não ocorre em homens castrados antes da puberdade (Scott, 1953), e por este motivo acreditava-se que os quadros de hiperplasia benigna pudessem resultar da produção exagerada de testosterona. No entanto, alguns estudos mostraram que os níveis séricos desse hormônio diminuem com o passar da idade (Vermeulen et al., 1989; Partin et al., 1991). Atualmente, acredita-se que a testosterona esteja implicada com o crescimento normal da próstata, mas tem um papel menos relevante na proliferação celular e no aumento glandular que ocorrem na HPB (Partin et al., 1991).

O papel da dihidrotestosterona (DHT) no desenvolvimento da HPB também tem sido investigado (Isaacs et al., 1983; Habib et al., 1994; Silver et al., 1994). Análises do tecido prostático em casos de HPB demonstram que a concentração local de DHT é três a quatro vezes maior que na glândula normal (Walsh et al., 1983). Este fenômeno estaria implicado no aumento da atividade da $5 \alpha$-redutase e em um desvio metabólico local, responsável por uma maior produção de DHT a partir de outros esteroides 
como a androstenediona (Bruchovsky et al., 1979; Isaacs et al., 1983). A influência da DHT e da $5 \alpha$-redutase na gênese da HPB é corroborada pela regressão dos sintomas e do volume prostático quando inibidores da $5 \alpha$ redutase são utilizados nesses casos (Gormley et al., 1992).

A DHT parece influenciar o desenvolvimento da HPB por meio de fatores de crescimento, tais como o fator de crescimento de fibroblastos (FGF), epitelial (EGF), de queratinócitos (KGF) e fator similar à insulina (IGF). Esses fatores e seus receptores celulares específicos são encontrados em maiores quantidades nas glândulas com hiperplasia do que em próstatas normais e provavelmente orquestram a proliferação celular anormal observada nos casos de HPB (Steiner, 1995; Lucia et al., 2008; Neuhouser et al., 2008).

O estudo de Coffey e Walsh (1990) sugere que nas fases iniciais de desenvolvimento da HPB, haveria uma predominância dos estímulos responsáveis pela proliferação celular, e nas fases mais avançadas, existiria uma menor atividade dos fatores responsáveis pela morte celular programada.

Este perfil funcional da HPB é bastante parecido com o observado no período fetal, onde as células do estroma exercem importante ação indutiva e estimuladora da proliferação epitelial (Rouleau et al., 1990). Esse possível mecanismo etiopatogênico da HPB tem sido chamado de "redespertar da capacidade embriônica" (McNeal, 1978). 


\subsubsection{Papel dos estrógenos}

O papel dos estrógenos na gênese da HPB também vem sendo estudado. Na glândula prostática os estrógenos possuem ação dupla. Essas ações se fazem de forma direta e indireta: indiretamente, os estrógenos suprimem a liberação hipofisária de LH (hormônio luteinizante), reduzindo assim a síntese testicular de testosterona, diminuindo seus níveis séricos e induzindo apoptose e atrofia epitelial prostática. Concomitantemente, atuando diretamente sobre os receptores estrogênicos-alfa (ERa), presentes no estroma prostático, os estrógenos estimulariam a diferenciação epitelial e proliferação celular (Risbridger et al., 2001).

\subsubsection{Inflamação e reação imunológica local}

Linfócitos T efetores são encontrados próximos aos dutos prostáticos, e o número destas células é cerca de seis vezes maior em homens com mais de 55 anos do que em jovens. Este achado poderia indicar que com o passar dos anos surge na próstata um fenômeno auto-imune gerado por algum antígeno específico local ainda não identificado (Theyer et al., 1992; Griffiths et al., 1993; Kramer et al., 2007). Como consequência, o microambiente que circunda as células epiteliais da próstata seria inundado por citocinas. Essas citocinas produzidas pelas células inflamatórias poderiam influenciar a produção local de fatores de crescimento no tecido prostático, simulando a resposta que ocorre no processo de cicatrização de feridas (Lucia et al., 2008). 
Ainda não existem dados que comprovem de maneira definitiva a hipótese de que fatores imunológicos estariam implicados com HPB, embora a suposição seja bastante racional (Antunes et al., 2010).

\subsection{Manifestações Clínicas}

Os pacientes com HPB apresentam manifestações referidas como "prostatismo", que podem ser divididas em sintomas de esvaziamento (esforço miccional, hesitância, jato fraco e interrompido, esvaziamento incompleto da bexiga) e sintomas de armazenamento (urgência, polaciúria, noctúria, capacidade vesical reduzida e incontinência) (Barry, 2001). Além disso, os pacientes acometidos pela doença podem evoluir com complicações como retenção urinária, litíase vesical, infecção urinária, insuficiência renal e hematúria microscópica.

\subsection{Diagnóstico}

Os pacientes com manifestações clínicas da HPB devem ser submetidos a uma avaliação que inclui toque digital da próstata, exame neurológico perineal, análise do sedimento urinário e avaliação da função renal por meio de dosagens da creatinina sérica (Bhargava et al., 2004). Os níveis séricos de PSA (antígeno prostático específico) elevam-se discretamente nos pacientes com HPB e o exame serve para investigar a presença concomitante de câncer de próstata. A ultrassonografia abdominal 
permite avaliar as dimensões da glândula e a presença de anormalidades do trato urinário superior e bexiga, mas esse exame costuma superestimar em até $30 \%$ o volume prostático real.

\subsection{Tratamento}

As opções terapêuticas variam desde a observação, tratamento farmacológico, procedimentos minimamente invasivos, até a ressecção transuretral da próstata e a cirurgia aberta. Sob o ponto de vista prático, pacientes com quadros de prostatismo incipiente devem ser apenas acompanhados periodicamente. Os casos com sintomas e desconforto moderados devem receber terapêutica medicamentosa e os pacientes com manifestações clínicas avançadas devem ser tratados cirurgicamente (Barry, 2001; Bhargava et al., 2004). Maior conhecimento sobre a fisiopatologia da HPB poderia contribuir para definição de preditores da doença, bem como para o desenvolvimento de terapias.

\subsection{Biologia Molecular da HPB}

As alterações genéticas associadas à HPB têm sido um interesse contínuo de muitos estudos (Tang et al., 2009). A elucidação de vias moleculares envolvidas no processo de desenvolvimento da doença é essencial para o entendimento de sua etiopatogenia e comportamento. Análises de expressão gênica e proteica por diferentes técnicas nos 
permitem investigar alterações em milhares de genes que podem estar envolvidos no aparecimento de muitas doenças.

Luo et al. (2002) relataram que um subconjunto de 76 genes envolvidos em várias funções celulares foram diferencialmente expressos entre tecidos de HPB e tecidos de próstatas normais. Os genes consistentemente superexpressos em HPB incluíram: um conjunto restrito de fatores de crescimento e as suas proteínas (por exemplo, IGF-1 - Fator de crescimento do tipo insulina 1 e IGF-2 - Fator de crescimento do tipo insulina 2, TGF- $\beta 3$ - Transforming growth factor beta 3 e BMP5 - Bone morphogenetic protein 5), hidrolases, proteases e inibidores de proteases (MMP2 - metaloproteinase da matriz 2 e a2-macroglobulina), enzimas de resposta ao stresse (COX2 - Ciclo-oxigenase 2) e GSTM5 (Glutathione Stransferase mu 5).

Em outro estudo conduzido por Prakash et al. (2002) diferenciações moleculares em cinco grupos foram analisadas usando microarrays. Um conjunto de genes que compreende principalmente expressed sequence tag (ESTs) e vários genes associados com a proliferação celular (por exemplo: serina quinase dependente de cálcio, fosfoserina fosfatase e p45), foram significativamente superexpressos no grupo de HPB sintomática e um outro subconjunto de genes, incluindo oncogenes e genes de resposta imediata (ras, v-jun, v-fos) foram altamente superexpressos no grupo de HPB comparado ao grupo de pacientes com câncer. Dois subconjuntos de genes, incluindo vários mediadores inflamatórios (por exemplo, linfotoxina $\beta$, imunoglobulinas, receptores de quimiocina e citocinas) e moléculas 
associadas à matriz extracelular (por exemplo, RANTES, osteonectina e lumican) foram capazes de distinguir os grupos de HPB sintomática e HPB com câncer, como um grupo distinto do grupo normal e do grupo com HPB assintomático. E um grupo de genes incluindo ESTs e open reading frame (ORFs) distinguiram o grupo de HPB assintomática de todos os outros grupos.

Diversas evidências indicaram também a influência da hereditariedade no desenvolvimento da HPB. Partin et al. (1994) observaram que gêmeos monozigóticos têm risco 3,3 vezes maior do que gêmeos dizigóticos de apresentar HPB quando um dos elementos da dupla é portador do problema. Em outro levantamento, Sanda et al. (1994) constataram que as chances cumulativas de cirurgia prostática são de $66 \%$ e de $17 \%$ respectivamente, em filhos de indivíduos com e sem HPB. A partir de estudos de segregação, demonstrou-se que os casos familiares de HPB resultam da transmissão de genes dominantes de acordo com o modelo mendeliano.

Díaz et al. (2009) concluíram que polimorfismos no gene ACE (enzima de conversão da angiotensina) e no gene AGT1R (receptor de angiotensina tipo 1) poderiam ser considerados como marcadores genéticos de risco para HPB. Outro estudo na Turquia demonstrou que o polimorfismo Ala49Thr no gene SRD5A2 (Steroid-5-alpha-reductase) é mais prevalente em homens com HPB (Izmirli et al., 2011). 
Os dados revelados nestas análises fornecem alvos potenciais para biomarcadores. A análise da expressão gênica tem sido uma fonte inesgotável de novas informações relacionadas a diversas doenças incluindo a HPB, mas outros fatores estão envolvidos nas vias moleculares até que se chegue à atividade da proteína, responsável por concluir as funções celulares. Nesse sentido, os micro RNA (miRNA) que são uma nova classe de ácidos ribonucleicos (RNA) com ação fundamental no controle da expressão dos genes, têm sido alvos de muitas pesquisas. Até o presente momento, o papel destas pequenas moléculas no controle da expressão gênica da HPB é desconhecido.

\subsection{Micro RNA}

MicroRNA compõem um grupo de moléculas pequenas de RNA que possuem entre 19 e 25 nucleotídeos, com ação fundamental na regulação da expressão dos genes nas plantas e em animais (Pillai et al., 2005). Essas pequenas moléculas foram descobertas há quase 20 anos (Lee et al., 1993) e desde então têm sido reconhecidas como moléculas que atuam especificamente no controle pós-transcricional na maioria do genoma dos eucariotos.

Atualmente existem mais de 1500 miRNAs relacionados com a regulação de mais de $30 \%$ dos genes humanos (www.mirnabodymap.org, data de acesso: 18/06/2012; Lewis et al., 2005), e envolvidos em uma série de processos celulares, como apoptose, diferenciação, desenvolvimento e 
proliferação celular (Reinhart et al., 2000), hematopoiese (Ambros, 2004), vias metabólicas e de sinalização e manutenção de células pluripotenciais, podendo atuar como supressores ou estimuladores de uma atividade celular específica. Além disso, a expressão anômala destes pequenos RNAs tem sido associada a diferentes patologias humanas (Ricarte Filho e Kimura, 2006).

\subsubsection{Biogênese dos miRNAs}

Os miRNAs são sintetizados pela RNA polimerase II e modificados após a transcrição pela adição de uma capa na região 5' e uma cauda poli A na região 3'. O precursor primário do miRNA, então denominado pri-miRNA, forma uma estrutura do tipo hairpin e, no núcleo, é submetido à ação do complexo microprocessador nuclear Drosha e então convertido em prémiRNA, uma molécula de fita dupla de aproximadamente 60-70 nucleotídeos (Han et al., 2004; Lee et al., 2004; Gregory et al., 2004; Kim, 2005). O prémiRNA é exportado do núcleo para o citoplasma pela Exportina-5, proteína especializada no transporte nucleocitoplasmático de macromoléculas, incluindo os ácidos ribonucleicos (Yi et al., 2003). No citoplasma, o prémiRNA é clivado pela enzima Dicer, transformando-se em um miRNA duplex contendo o miRNA maduro e sua fita complementar. Novamente a Dicer cliva a dupla fita e produz o miRNA maduro de fita única, que então é incorporado a um complexo efetor denominado RISC (complexo silenciador induzido por RNA) (Lee et al., 2003; Carmell e Hannon, 2004; Bartel, 2004). 
O RISC guia o miRNA maduro até seu RNAm alvo e então ocorre a repressão da tradução da proteína ou a promoção da degradação do RNA. Esta ação dependerá do grau de complementariedade do miRNA com o seu RNA mensageiro (RNAm) alvo (Figura 1), podendo este pareamento ser perfeito ou incompleto (Meister et al., 2004; Pillai et al., 2005).

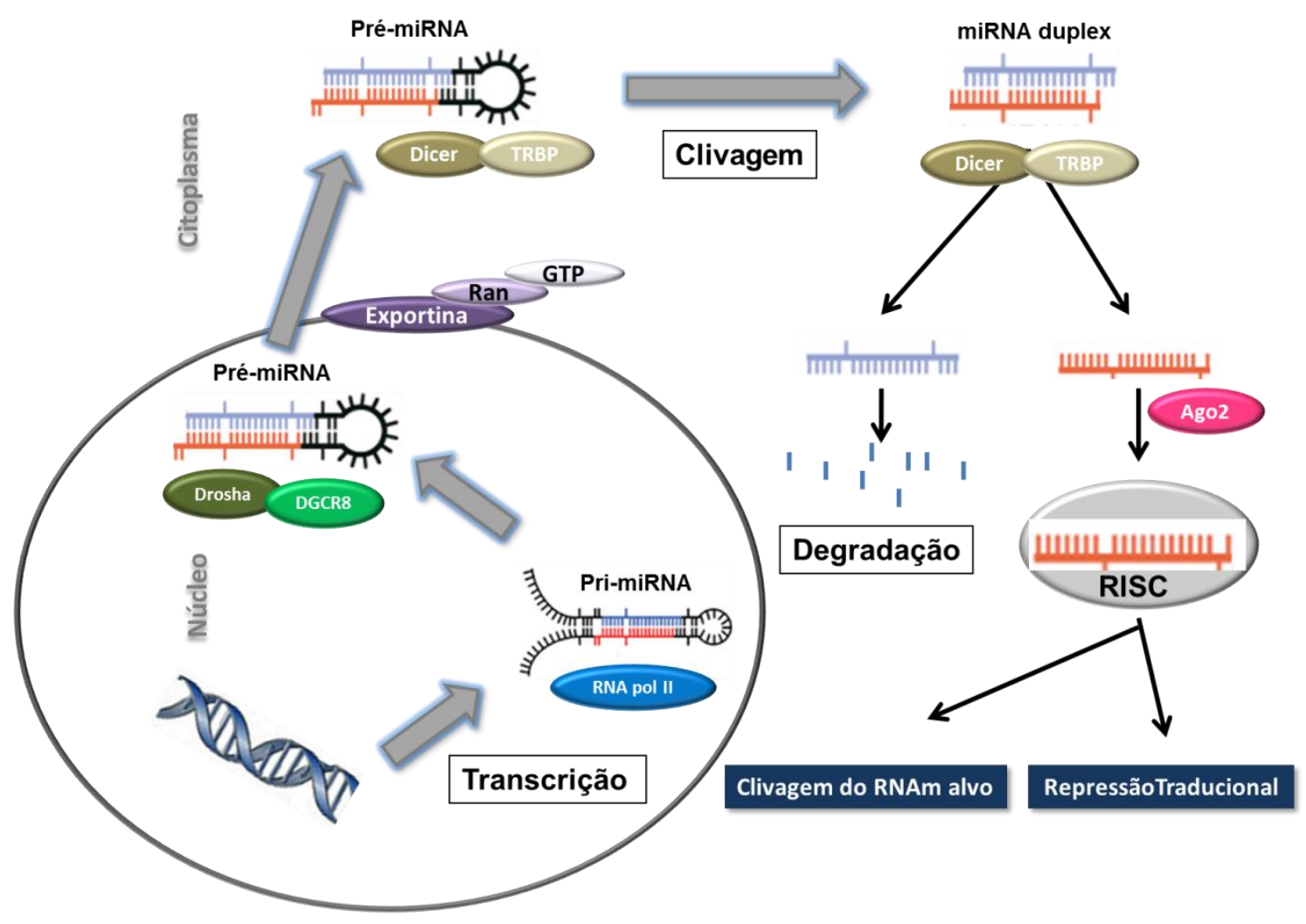

Figura 1 - Representação esquemática da biogênese e ação supressora pós-transcripcional dos miRNA 


\subsubsection{Funções dos miRNAs}

Durante os últimos anos, o número de genes humanos que são conhecidamente regulados pelos miRNAs aumentou rapidamente ( $\mathrm{He}$ e Hannon, 2004; Chen, 2005). Um mesmo miRNA pode ter mais de 100 RNAm alvos com funções diversas, acreditando-se que de um terço a metade dos RNA humanos sejam controlados por este mecanismo (Yoon et al., 2005).

Os miRNAs estão localizados nas regiões intergênicas assim como em íntrons e podem fazer parte da fita codificante ou não codificante do DNA (ácido desoxirribonucleico). Metade dos miRNAs estão localizados nos chamados sítios frágeis do genoma, cujas anormalidades estão associadas a diversas patologias, entre elas o câncer (Calin et al., 2004).

Alguns miRNAs, como o 143 e o 145, desempenham importante papel na diferenciação e proliferação de células musculares lisas no músculo cardíaco e esquelético, tendo ainda a capacidade de controlar o fenótipo quiescente versus proliferativo destas células (Van Rooij e Olson, 2007; Condorelli e Dimmeler, 2008; Chen et al., 2009; Cordes e Srivastava, 2009). O miR-143 tem como alvos os genes KRAS e ERK5 e o miR-145 tem como alvos os genes MAP3K3 e MAP4K4. Suas ações no tecido muscular liso da próstata nunca foram descritas (Figura 2). 


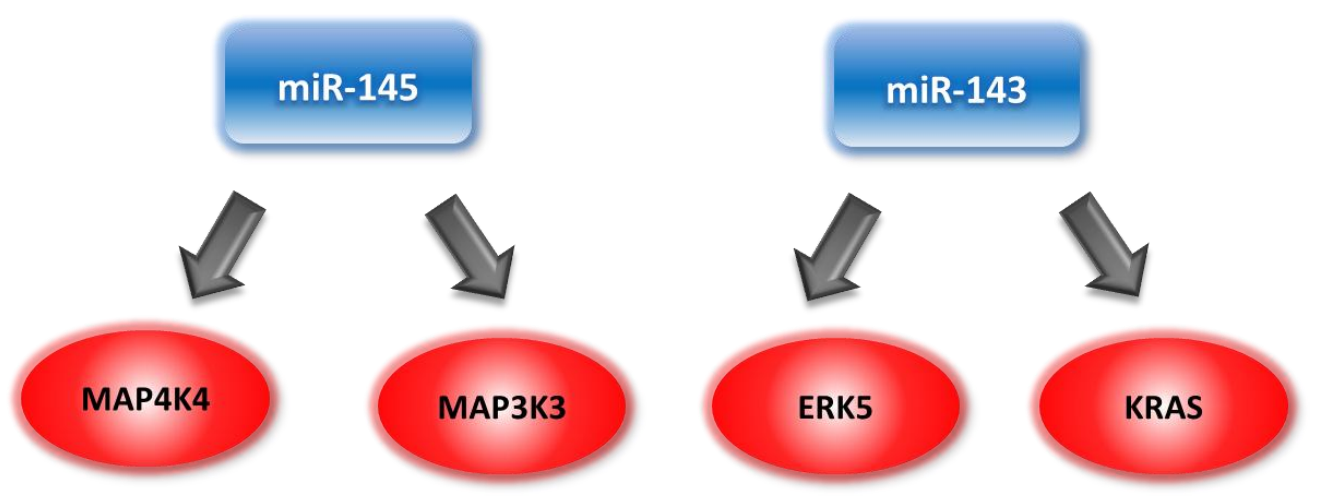

Figura 2 - miR-145 e seus genes alvo MAP4K4 e MAP3K3 e miR-143 e seus genes alvo KRAS e ERK5

Embora a grande maioria dos estudos se atente para o papel dos miRNAs no desenvolvimento e progressão de doenças, diagnóstico, prognóstico e estratégias terapêuticas, eles são fundamentais nos fenômenos de embriogênese, desenvolvimento e diferenciação celular, proliferação e metabolismo (Dalmay, 2008).

\subsection{Justificativa}

Como citado anteriormente, nos casos de HPB observamos uma marcante hiperplasia do componente muscular liso da próstata, e uma intensa produção de peptídeos de crescimento por este compartimento da glândula. Neste sentido, o estudo, no tecido prostático, de miRNAs envolvidos com a diferenciação e proliferação de células musculares lisas pode resultar em duas importantes contribuições: (1) aprimorar o entendimento da etiopatogenia da hiperplasia estromal da próstata; e (2) 
servir como base para o desenvolvimento de novos alvos terapêuticos no tratamento da doença. Ademais, ainda não existem estudos que exploraram a expressão de miRNA na HPB. 
2. OBJETIVOS 


\subsection{Objetivo primário}

Analisar a expressão do miR-143 e de seus genes e proteínas alvo ERK5 e KRAS e do miR-145 e dos seus genes e proteínas alvo MAP3K3 e MAP4K4 em pacientes portadores de HPB comparados com pacientes controle sem HPB, a fim de estabelecer a interação entre miRNA, gene alvo e seu produto proteico final.

\subsection{Objetivos secundários}

Comparar os perfis de expressão dos miRNA 143 e 145, dos genes ERK5, KRAS, MAP3K3 e MAP4K4 e as proteínas por eles codificadas com alguns parâmetros clínicos dos pacientes: PSA, uso de cateter vesical, peso da próstata e idade. 
3. MÉtodos 


\subsection{Tipo do Estudo}

Estudo experimental, exploratório, retrospectivo.

\subsection{Pacientes}

O estudo consistiu na análise de espécimes de 44 pacientes com diagnóstico de HPB, tratados cirurgicamente por ressecção transuretral da próstata e prostatectomia aberta no Hospital das Clínicas da Faculdade de Medicina da Universidade de São Paulo (HCFMUSP) no período de setembro 2010 a julho de 2011. O grupo controle foi representado por fragmentos prostáticos (zona de transição) de dois pacientes jovens (média de 30 anos) doadores de órgãos, coletados dentro do mesmo hospital. Tentamos nos aproximar de um grupo controle ideal, utilizando amostras de pacientes jovens considerando que a HPB é uma doença relacionada à idade, cuja incidência começa a aumentar a partir dos 40 anos.

\subsubsection{Critérios de inclusão}

1. Pacientes com diagnóstico de HPB

2. Indicação de tratamento cirúrgico 


\subsubsection{Critérios de Exclusão}

1. Cirurgia prostática prévia

2. Radioterapia pélvica

3. Diagnóstico de câncer da próstata

4. Uso de inibidores da 5 alfa-redutase (pois podem influenciar o volume prostático).

Foram realizadas biópsias pré-operatórias nos pacientes que possuíam PSA elevado. Como a maioria dos pacientes com HPB possuem PSA > 2,5 ng/ml, as biópsias foram solicitadas de acordo com julgamento individualizado. Para isso foi considerada a idade, a densidade, a relação livre/total e a velocidade de alteração no tempo de cada paciente.

Os parâmetros clínicos dos pacientes estudados estão representados na tabela 1. Os pacientes foram subdivididos em grupos de acordo com os parâmetros clínicos. Foram analisados os níveis séricos de PSA préoperatório, divididos em PSA $\leq 4 \mathrm{ng} / \mathrm{ml}$ e PSA $>4 \mathrm{ng} / \mathrm{ml}$, uso ou não de cateter vesical, volume prostático na ultrassonografia, divididos em $\leq 60 \mathrm{~g} \mathrm{e}$ $>60 \mathrm{~g}$, e idade dos pacientes, divididos em $\leq 65$ anos e $>65$ anos. 
Tabela 1 - Características demográficas dos 44 pacientes submetidos a tratamento cirúrgico para HPB

\begin{tabular}{cc}
\hline PSA (ng/ml) & \\
Média & 4,7 \\
Min - Max & $01-30,2$ \\
$\leq 4 \mathrm{n}(\%)$ & $28(63,6 \%)$ \\
$>4 \mathrm{n}(\%)$ & $16(36,4 \%)$ \\
\hline Uso de catéter vesical & \\
Sim n (\%) & $21(47 \%)$ \\
Não n (\%) & $23(53 \%)$ \\
Volume prostático (gramas) & \\
Média & 67 \\
Min - Max & $24-200$ \\
$\leq 60 \mathrm{n}(\%)$ & $15(34 \%)$ \\
$>60 \mathrm{n}(\%)$ & $29(66 \%)$ \\
Idade (anos) & \\
Média & 66 \\
Min - Max & $46-88$ \\
$\leq 65 \mathrm{n}(\%)$ & $21(47 \%)$ \\
$>65 \mathrm{n}(\%)$ & $23(53 \%)$ \\
\hline
\end{tabular}

Os miRNAs descritos e seus genes alvo foram avaliados através da técnica de reação em cadeia da polimerase quantitativa em tempo real (qRTPCR). As proteínas alvo foram avaliadas por Western Blotting (WB).

\section{3 Ética}

Todas as amostras utilizadas neste estudo foram codificadas, garantindo sua confidencialidade. Este projeto foi submetido ao comitê de ética em pesquisas do HCFMUSP, tendo sido aprovado na reunião de 24/06/2010 (protocolo oㅜ 0258/10). Os pacientes foram informados sobre os objetivos deste estudo e assinaram o termo de consentimento livre e esclarecido (Anexo A). 


\subsection{Processamento das Amostras}

Os espécimes cirúrgicos foram coletados pelo orientador deste trabalho, imediatamente após o procedimento cirúrgico, sendo seccionado

um fragmento de $1 \mathrm{~cm}^{2}$ proveniente da zona de transição da próstata, armazenado imediatamente em criotubo Eppendorf de $1,5 \mathrm{ml} \mathrm{com} 1 \mathrm{ml}$ de RNA holder ${ }^{\circledR}$ (fixador de RNA), sendo tomados todos os cuidados para evitar a contaminação das amostras e degradação do RNA. Os espécimes então foram mantidos em freezer $-80 \stackrel{\circ}{\circ}$ no Laboratório de Investigação Médica (LIM-55 da disciplina de Urologia) da Faculdade de Medicina da Universidade de São Paulo (FMUSP) até o momento do processamento.

\subsection{Isolamento do miRNA, do RNA e Síntese do cDNA}

\subsubsection{Isolamento do miRNA e do RNA dos espécimes cirúrgicos}

Para extração de miRNA utilizamos o kit de isolamento miRVana ${ }^{\circledR}$ miRNA (Ambion, Austin, Tx), de acordo com as recomendações do fabricante. Este kit permite o isolamento de todos os tipos de RNA, e por isso o utilizamos para a extração do miRNA e do RNA dos espécimes cirúrgicos.

O tecido congelado foi transferido para um recipiente de porcelana e então foi adicionado nitrogênio líquido. $O$ tecido foi então macerado com auxílio do pistilo. Ao tecido macerado foram adicionados $500 \mu \mathrm{l}$ do tampão de lise (10 vezes o volume da massa tecidual), e 10\% do volume total de 
aditivo para homogeneização e logo após os tubos foram colocados em gelo por 10 minutos. Foram adicionados $500 \mu \mathrm{l}$ de fenol-clorofórmio, e as amostras foram agitadas em vortex e centrifugadas na velocidade máxima (10.000g) por 5 minutos a temperatura ambiente. A fase aquosa foi então removida e transferida para um novo tubo onde foi adicionado um terço do volume de etanol $100 \%$ a temperatura ambiente. A solução então foi passada para o filtro (coluna GFX) e as amostras foram novamente centrifugadas a $10.000 \mathrm{~g}$ por 1 minuto. Neste momento o filtro contém RNA e o filtrado, os pequenos RNA. O filtro foi então reservado. Ao filtrado foi adicionado $2 / 3$ do volume de etanol e transferidos para uma nova coluna, centrifugadas e o filtrado foi descartado. Retomando os filtros com o RNA, foram realizadas lavagens com soluções próprias do kit, intercaladas com centrifugações. Após o descarte do filtrado, centrifugamos por mais 1 min a $10.000 \mathrm{~g}$ para secagem da coluna. As colunas foram então repassadas para um novo tubo e então adicionamos $100 \mu \mathrm{l}$ de água livre de RNase préaquecida a $95{ }^{\circ} \mathrm{C}$, no centro da coluna. Após 1 min a temperatura ambiente, centrifugamos a coluna e os miRNA e o RNA foram armazenados a $-80{ }^{\circ} \mathrm{C}$ até sua utilização.

A pureza e concentração do miRNA e do RNA foram mensuradas em espectrofotômetro Nanodrop ${ }^{\circledR}$ (ND-1000, Wilmington, EUA) (260/280nM). 


\subsubsection{Síntese do DNA complementar}

O DNA complementar (cDNA) do miRNA foi obtido usando TaqMan $^{\circledR}$ miRNA Reverse Transcription kit (Applied Biosystems, Foster City, CA). Uma quantidade de $500 \mathrm{ng} / \mu \mathrm{l}$ de miRNA foi diluída em $20 \mu \mathrm{l}$ de água. Deste volume $3 \mu$ foi submetido à transcrição reversa, onde foram adicionados $7 \mu \mathrm{l}$ de mix contendo os reagentes do kit: $0,15 \mu \mathrm{l}$ de DNTP mix, $0,5 \mu \mathrm{l}$ da enzima transcriptase reversa, $1,5 \mu \mathrm{l}$ do tampão da enzima, $0,19 \mu \mathrm{l}$ de inibidor de RNAse, 3,66 $\mu \mathrm{l}$ de água livre de nucleasse e $1 \mu \mathrm{l}$ de primer stem-loop com sequência específica para os miRNA (Tabela 2), totalizando $10 \mu \mathrm{l}$ de cDNA. A reação foi realizada em equipamento PCR Vertiti ${ }^{\circledR}$ (Applied Biosystem, Foster City, CA) seguindo os seguintes parâmetros: 30 min a $16{ }^{\circ} \mathrm{C}, 30$ min a $42 \stackrel{\circ}{\circ} \mathrm{C}$ e 30 min a $85^{\circ} \mathrm{C}$.

A síntese do cDNA do RNA foi realizada utilizando-se o kit HighCapacity cDNA Reverse Transcription ${ }^{\circledR}$ (Applied Biosystems) que utiliza a Transcriptase reversa Multiscribe ${ }^{\mathrm{TM}}$ e primers randômicos. O RNA total foi

diluído em $\mathrm{H}_{2} \mathrm{O}$ livre de nucleases em um volume final de $20 \mu \mathrm{l}$ e concentração de $500 \mu \mathrm{l} / \mathrm{ng}$. A este volume foram acrescentados $4 \mu \mathrm{l}$ de oligonucleotídeos randômicos (10X), 1,6 $\mu \mathrm{l}$ do mix de dNTPs (25X), $4 \mu \mathrm{l}$ do tampão da enzima (10X), $2 \mu \mathrm{l}$ da enzima transcriptase reversa e 8,4 $\mu \mathrm{l}$ de água livre de nuclease. A solução foi então submetida a ciclos de temperaturas $\left(25 \stackrel{\circ}{\circ} \mathrm{C}\right.$ por $10 \mathrm{~min}, 3{ }^{\circ} \stackrel{\circ}{\mathrm{C}}$ por $120 \mathrm{~min}$ e $85{ }^{\circ} \mathrm{C}$ por $\left.5 \mathrm{~min}\right)$ no termociclador Vertiti ${ }^{\circledR}$ (Applied Biosystems). Ao final das reações ambos os 
cDNA foram armazenados a $-20{ }^{\circ} \mathrm{C}$ até 0 uso. As reações estão esquematizadas na figura 3.

Tabela 2 - miRNA estudados por qRT-PCR e seus genes alvo

\begin{tabular}{ccc}
\hline miRNA & Genes alvo & Referência \\
\hline $\mathbf{1 4 3}$ & ERK5, KRAS & Michael et al. (2003); Akao (2006); Faber (2009) \\
$\mathbf{1 4 5}$ & MAP3K3, MAP4K4 & Michael et al. (2003); Akao (2006); Sempere et al. (2007) \\
\hline
\end{tabular}
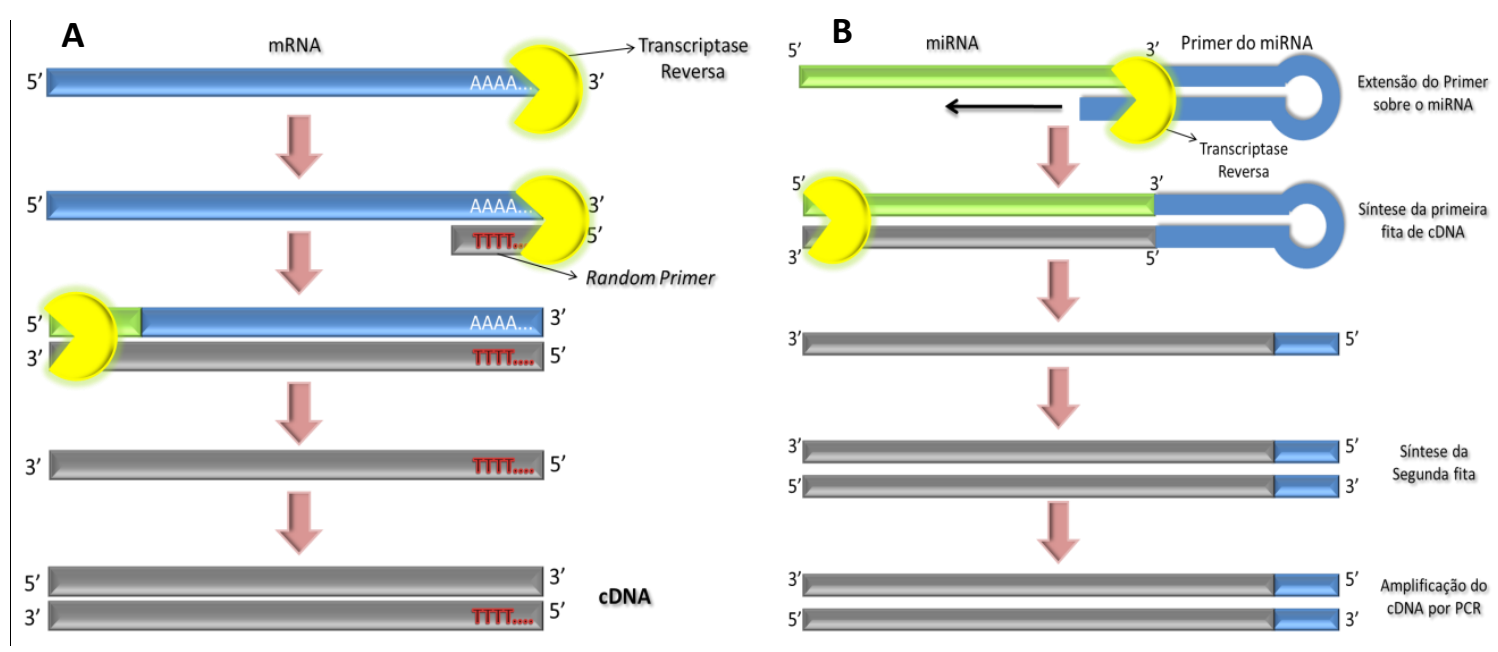

Figura 3 - Esquematização da reação de síntese do DNA complementar a partir do RNA (A) e do miRNA (B) isolados do tecido. Fonte: Dip NG, 2012.

\subsection{Análise da Expressão de miRNA e RNA}

A expressão dos miRNA e RNA estudados foi avaliada a partir do cDNA utilizando a metodologia de transcrição reversa seguida da reação em cadeia da polimerase em tempo real quantitativa (qRT-PCR) no sistema $A B I$ 7500 Fast RT-PCR no modo standard utilizando-se Master Mix PCR Taqman 
Universal (Applied Biosystems, Foster City, CA). A expressão de miRNA e RNA individuais foi analisada usando primers sequência-específicos.

Este protocolo $\operatorname{TaqMan}^{\circledR}$ utiliza dois iniciadores não fluorescentes e uma sonda com dupla marcação que se anela à região localizada entre os iniciadores. Esta marcação dupla é formada por um fluoróforo que emite luz quando excitado e um quencher que absorve luz emitida pelo fluoróforo. Durante os ciclos da PCR, a sonda é quebrada pela Taq polimerase na etapa de extensão do iniciador anelado. Esta quebra da sonda elimina a absorção pelo quencher que pode ser então medida através de uma câmera situada na parte superior do equipamento. A quantificação da emissão absorvida pela câmera após quebra da sonda permite a quantificação indireta do miRNA e do RNA alvo contido na reação após cada ciclo da PCR (Figura 4). 


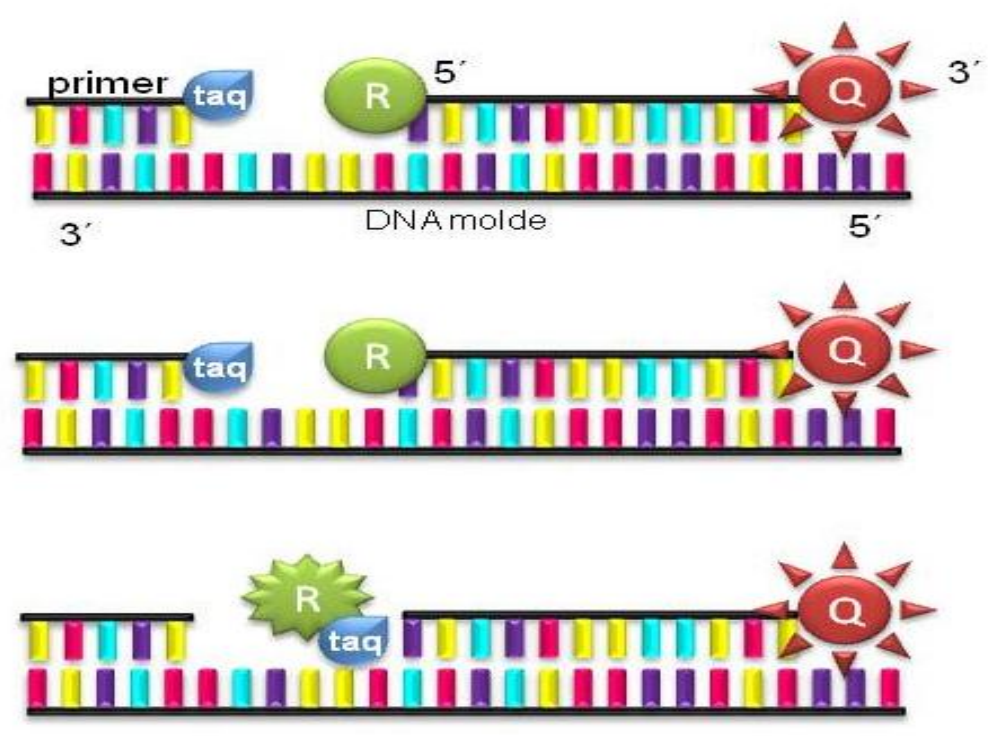

Figura 4 - Esquema de amplificação pela técnica de PCR em tempo real quantitativo (qRT-PCR). Fonte: Reis ST, 2011.

Para amplificação dos fragmentos desejados as reações foram feitas com $0,5 \mu \mathrm{l}$ de uma solução contendo um par de primer e a sonda (com a marcação), $5 \mu \mathrm{l}$ do TaqMan Master Mix, 3,5 $\mu$ l de água nucleasse free e $1 \mu \mathrm{l}$ de cDNA, somando um total de $10 \mu \mathrm{l}$ para cada reação. As condições das reações foram: 2 min a $50 \stackrel{\circ}{\circ}, 10$ min a $95^{\circ} \mathrm{C}$ e 40 ciclos de 15 seg a $95^{\circ} \mathrm{C}$ e 1 min a $60{ }^{\circ} \mathrm{C}$. O nível de expressão dos miRNA e dos genes alvo foi obtido pela quantificação relativa e dos níveis de expressão em vezes determinado pelo método $2^{-\triangle \Delta}{ }^{\mathrm{CT}}$ (Livak et al., 2001). No gráfico logarítmico, esse método padroniza a expressão do controle normal como uma linha basal (representada pelo número 1) e a expressão relativa de cada miRNA e RNA para cada amostra de HPB é demonstrada em vezes o normal para mais nos casos de superexpressão e para menos nos de subexpressão. 
Todas as reações foram realizadas em duplicata e o RNU43 foi usado como controle endógeno dos miRNA estudados, enquanto que o gene da 32- microglobulina $\left(B_{2} M\right)$ desempenhou esse papel para os RNA estudados. A tabela 3 descreve os ensaios utilizados.

Tabela 3 - Primers utilizados para quantificação da expressão dos microRNAs 143 e 145, e seus genes alvo na HPB

\begin{tabular}{cc}
\hline Gene & Identificação do Ensaio \\
\hline miR-143 & 000466 \\
\hline miR-145 & 000467 \\
RNU43 & 001095 \\
ERK5 & Hs00964718_m1 \\
KRAS & Hs01025520_m1 \\
\hline MAP3K3 & Hs00176747_m1 \\
\hline MAP4K4 & Hs00377415_m1 \\
\hline B2M & Hs99999907_m1 \\
\hline
\end{tabular}

\subsection{Western Blotting}

A expressão proteica dos genes alvo ERK5, KRAS, MAP3K3 e MAP4K4 foi avaliada através da técnica de Western Blotting. Esta técnica identifica com anticorpos específicos, proteínas que foram separadas umas das outras de acordo com seu tamanho por eletroforese em gel. O blot é uma membrana, quase sempre de nitrocelulose ou PVDF (fluoreto de 
polivinilideno). O gel é colocado ao lado da membrana e a aplicação de uma corrente elétrica induz as proteínas do gel a passar para a membrana onde elas aderem. A membrana é, então, uma réplica do padrão do gel de proteínas, e é posteriormente submetida à incubação com anticorpos.

Foram utilizados espécimes de 38 pacientes de nosso $\mathrm{n}$ inicial de 44 em que analisamos a expressão dos miRNA e do RNA. Em seis pacientes, a quantidade de tecido impediu a realização da extração proteica. Para os anticorpos ERK5 e MAP3K3, utilizamos o anticorpo secundário goat anti rabbit e para os anticorpos KRAS e MAP4K4 utilizamos o anticorpo secundário goat anti mouse. Utilizamos o anticorpo $\beta$-actina como controle para normalização do nosso trabalho. A tabela 4 descreve os anticorpos utilizados bem como suas diluições.

Tabela 4 - Anticorpos utilizados para detecção da expressão proteica

\begin{tabular}{ccc}
\hline Anticorpo & Marca & Diluição \\
\hline ERK5 & Upstate & $1: 1000$ \\
KRAS & Abnova & $1: 500$ \\
MAP3K3 & Upstate & $1: 1000$ \\
MAP4K4 & Abnova & $1: 500$ \\
B-ACTINA & Millipore & $1: 500$ \\
\hline
\end{tabular}


A preparação das amostras foi realizada em gelo e da maneira mais rápida possível para prevenir a degradação por proteases. As amostras foram maceradas no equipamento Tissue Laser, com tampão de lise RIPA (Lysis Buffer, Millipore) contendo inibidores de protease e fosfatase. A quantidade de tampão colocada foi de seis vezes em relação ao peso do fragmento. As amostras foram deixadas por 30 minutos no gelo. Procedeuse então a centrifugação das amostras em centrífuga refrigerada por 20 minutos, a $15.000 \mathrm{rpm}$ em $4 \stackrel{\circ}{\circ} \mathrm{C}$. O sobrenadante foi recolhido e dividido em alíquotas e congelado a $-80^{\circ} \mathrm{C}$.

Uma pequena quantidade das proteínas foi separada e realizou-se a dosagem no espectrofotômetro Nanodrop ${ }^{\circledR}$ (ND-1000, Wilmington, EUA), com o Pierce ${ }^{\circledR}(660 \mathrm{~nm}$ Protein Assay, Thermo). Uma curva de calibração foi feita no equipamento para determinar um padrão de concentração das proteínas, utilizando-se albumina de soro bovino (BSA). BSA é um padrão de proteínas usado com frequência (Figura 5).

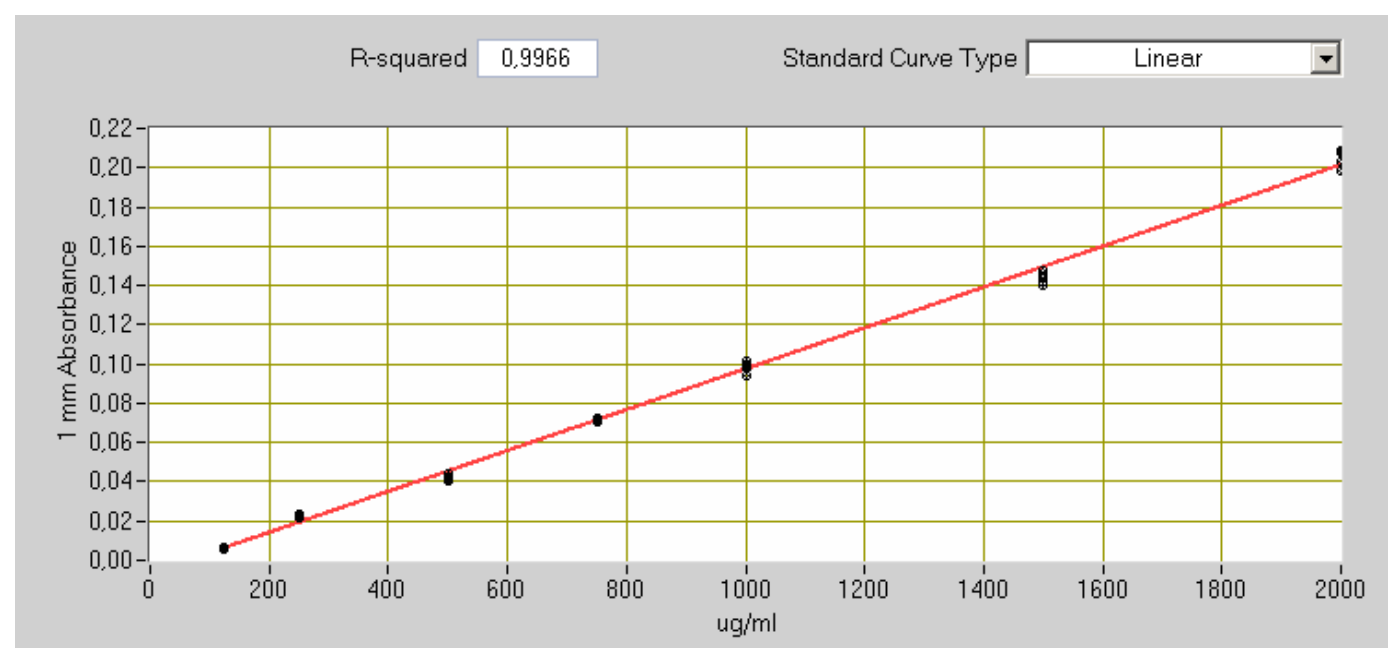

Figura 5 - Curva de calibração de concentração de proteínas 
Os anticorpos normalmente reconhecem uma pequena porção da proteína de interesse (epítopo) e este domínio muitas vezes está dentro da conformação 3D da proteína. Para permitir o acesso do anticorpo para essa região da proteína é necessário desnaturá-la. Foi adicionado às proteínas, um tampão de amostra, chamado Laemmli 2x, na proporção de 1:1. As amostras foram então aquecidas a $95 \stackrel{\circ}{\mathrm{C}}$ por 5 minutos.

Para separarmos as proteínas de acordo com seu peso molecular, utilizamos o gel de poliacrilamida, que é formado a partir da polimerização de dois compostos, acrilamida e bis-acrilamida. Os géis utilizados foram comprados prontos (Bio-Rad; Mini-Protean ${ } \mathrm{TGX}^{\mathrm{TM}}$ ) na porcentagem de $12 \%$, determinada de acordo com o tamanho das proteínas estudadas.

Foram utilizados lisados celulares como controles positivos para demonstrar a eficiência dos nossos procedimentos. O lisado 3T3/A31 murine fibroblast cell line (Millipore) foi utilizado para os anticorpos MAP3K3 e MAP4K4 e o lisado HeLa cell lysate (Millipore) foi utilizado para ERK5 e KRAS. Os controles positivos foram determinados com base na literatura.

Os marcadores de peso molecular permitem a determinação do tamanho da proteína e também monitoram o progresso da corrida eletroforética. Em nossos experimentos utilizamos o Precision Plus Protein ${ }^{T M}$ Standards (Bio-Rad).

As amostras de proteínas na concentração de $50 \mu \mathrm{g} / \mathrm{ml}$ misturadas a tampão de amostra e já desnaturadas, foram carregadas nos géis. Os géis foram submersos em tampão de corrida e uma carga de $80 \mathrm{~V}$ foi aplicada 
por 30 minutos para corrida do gel stacking e depois foi colocada uma voltagem de $100 \mathrm{~V}$ por aproximadamente uma hora e meia para corrida no gel de separação. Quando as proteínas atingiam o fundo do gel, a energia era desligada.

Para a transferência úmida, utilizamos um tampão de transferência feito a base de glicina e tris (1x) que deve ser usado sempre gelado. Neste tipo de transferência o gel e a membrana foram prensados entre esponjas e papel absorvente umedecidos com tampão de transferência. Um cassete foi utilizado nesse esquema para apertar todos os elementos (esponja/papel/gel/membrana/papel/esponja) em conjunto. Utilizamos membrana de PVDF que foi previamente hidratada, conforme instruções. $O$ esquema de transferência, chamado de "sanduíche" foi submerso em tampão de transferência e um campo elétrico de $300 \mathrm{~mA}$ foi aplicado por 2 horas. Todo o processo foi feito com gelo. Para verificar o sucesso da transferência, mergulhamos a membrana em Ponceau Red (Ponceu $S$ Solution - Sigma), para visualização das bandas de proteínas.

A incubação dos anticorpos foi realizada utilizando-se o aparelho SNAP (SNAP i.d. ${ }^{\circledR}$ system - Millipore) que otimiza os tempos de incubação utilizando um sistema a vácuo. Realizamos primeiramente o bloqueio da membrana para impedir ligação inespecífica dos anticorpos primário e/ou secundário na membrana. A solução de bloqueio utilizada foi BSA (1\%) (Albumin, from bovine serum - Sigma) diluído em TBS-T (1x) (tampão tris salino Tween 20) por 15 segundos. 
Os anticorpos primários foram diluídos em BSA (1\%) na diluição sugerida pelo fabricante e especificada na tabela 4. A incubação foi feita por 10 minutos a temperatura ambiente. Depois dessa etapa, as membranas foram lavadas várias vezes com TBS-T (1x) para remoção do anticorpo primário residual. $\mathrm{O}$ anticorpo secundário foi diluído da mesma maneira que o primário na diluição sugerida pelo fabricante. A incubação foi realizada por 10 minutos a temperatura ambiente e novamente a membrana foi lavada com TBS-T.

Utilizamos o substrato Luminata ${ }^{\mathrm{TM}}$ Forte (Western HRP Substrate Millipore) para detecção das proteínas. Para obtenção das imagens utilizamos o Alliance 4.7 (Uvitec Cambridge). O equipamento possui uma câmera dentro de um gabinete, que detecta a quimioluminescência que emana da membrana, transformando o sinal em uma imagem digital para análise rápida com o software (Alliance 16.06) fornecido com a máquina de deteç̧ão.

\subsection{Análise Estatística}

Para análise estatística foi utilizado o software SPSS 19.0. Para comparação da expressão dos genes, miRNA e proteínas com as variáveis clínicas nós utilizamos o Teste T de Student para variáveis homogêneas, e Mann-Whitney para variáveis não homogêneas. 
Em toda análise estatística foi adotado um nível de significância de $5 \%$, ou seja, foram considerados como estatisticamente significantes os resultados que apresentaram $p$-valor inferior a $5 \%(p<0,05)$. 


\section{Resultados}




\subsection{Padrão de Expressão dos miRNAs e seus Genes Alvo}

A análise do miR-143 e dos genes ERK5 e KRAS através do método de qRT-PCR nos tecidos de HPB demonstrou que o miR-143 está superexpresso na maioria dos casos, assim como o gene KRAS e que o gene ERK5 está subexpresso na maioria dos casos de tecido hiperplásico em comparação com tecido de próstata normal (Figura 6) (Tabela 5).

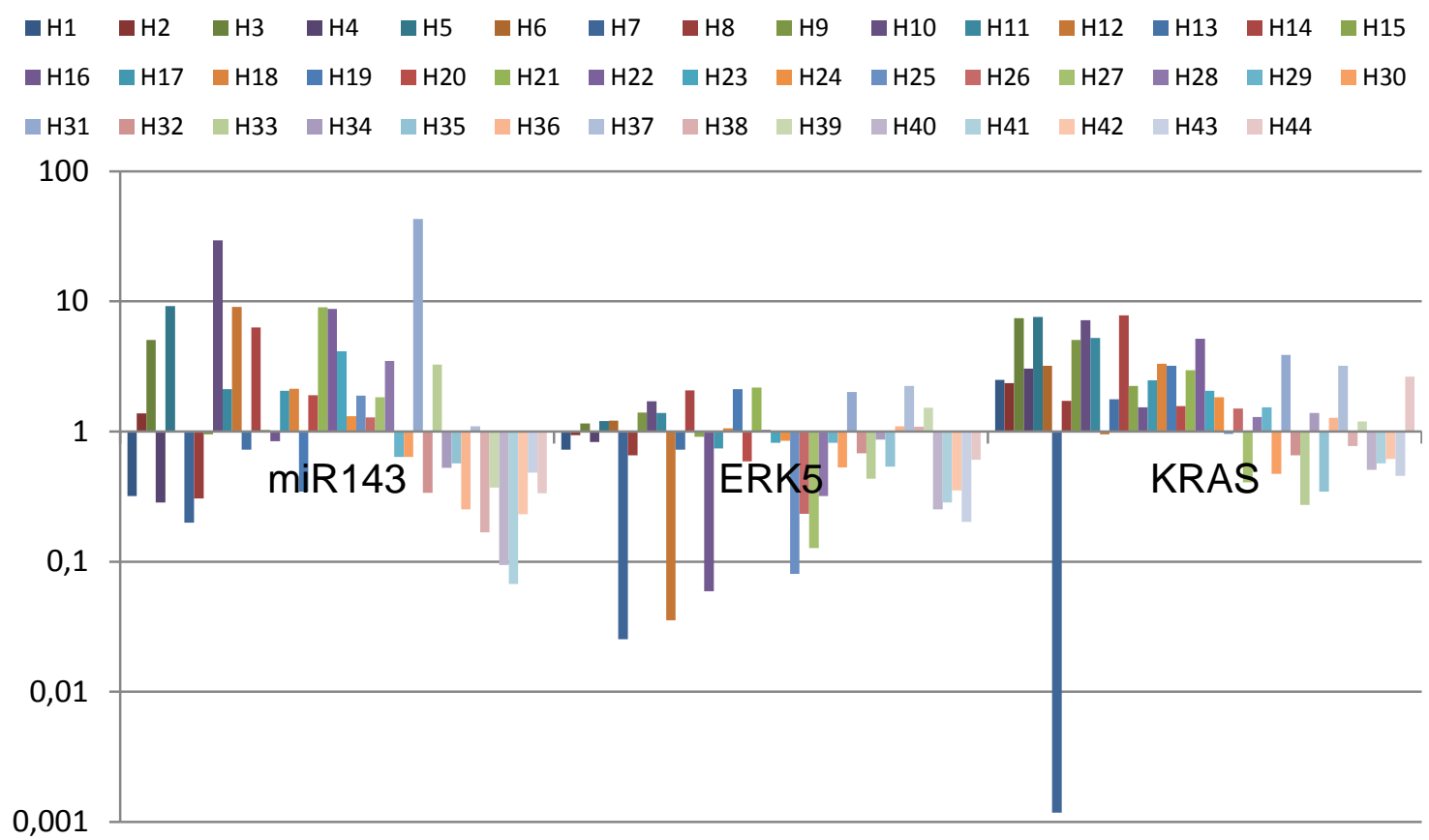

Figura 6 - Perfil de expressão do miR-143 e dos genes ERK5 e KRAS em 44 pacientes com HPB

A análise do miR-145 e dos genes MAP3K3 e MAP4K4 através do método de qRT-PCR nos tecidos de HPB demonstrou que o miR-145 está superexpresso, assim como o gene MAP3K3 e que o gene MAP4K4 está fortemente subexpresso nos tecidos hiperplásicos em comparação com tecido de próstata normal (Figura 7)(Tabela 5). 


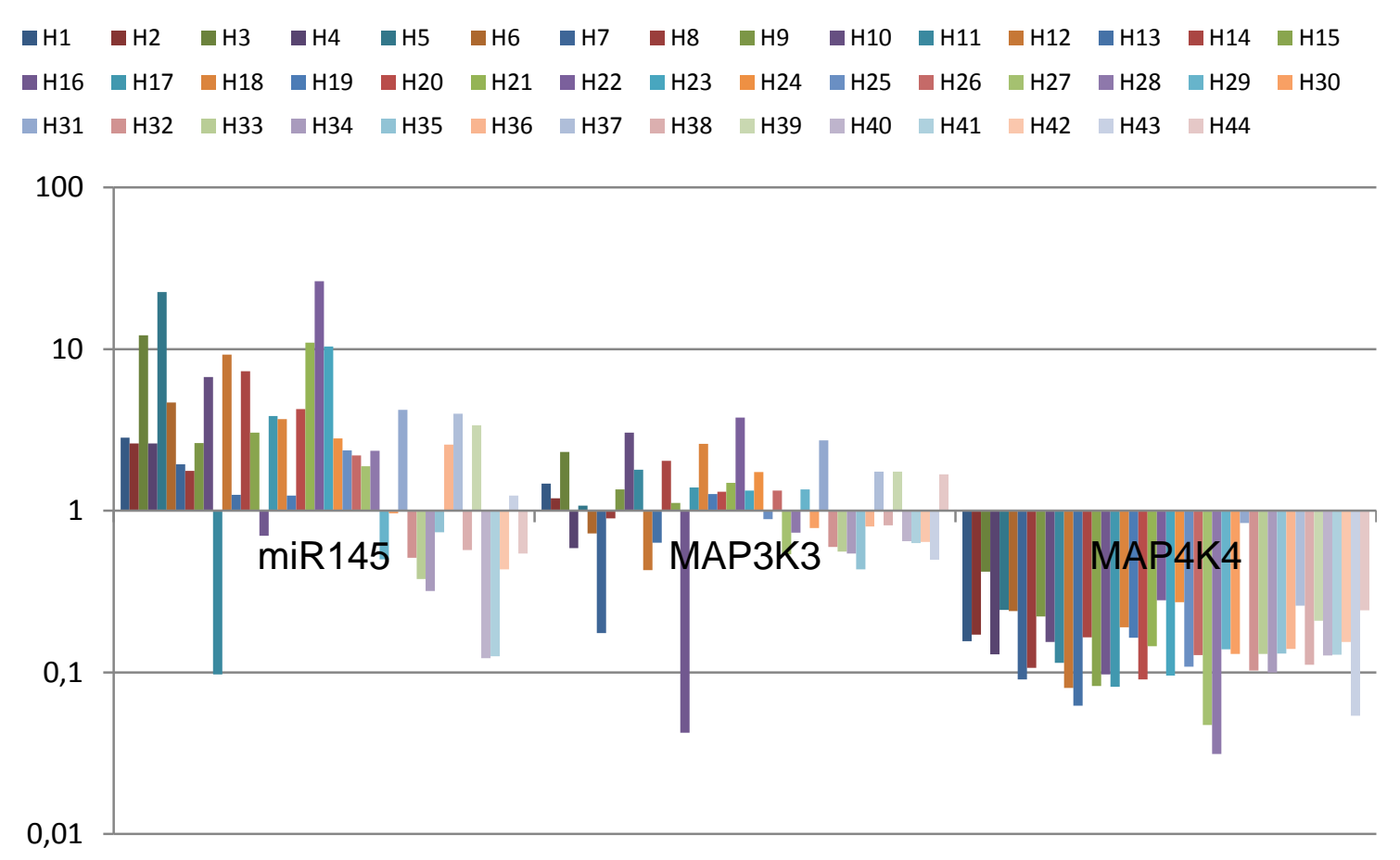

Figura 7 - Perfil de expressão do miR-145 e dos genes MAP3K3 e MAP4K4 em 44 pacientes com HPB

Tabela 5 - Média de expressão dos miRNAs e genes estudados nos 44 pacientes com HPB, comparados com o controle normal

\begin{tabular}{ccccccc}
\hline & miR-143 & ERK5 & KRAS & miR-145 & MAP3K3 & MAP4K4 \\
\hline Média & 3,60 & 0,88 & 2,41 & 3,97 & 1,21 & 0,16 \\
Desvio padrão & 7,80 & 0,61 & 2,09 & 5,41 & 0,78 & 0,12 \\
Superexpressão & $62,5 \%$ & $40,5 \%$ & $79,4 \%$ & $73,8 \%$ & $61,5 \%$ & $0 \%$ \\
Subexpressão & $37,5 \%$ & $59,4 \%$ & $20,5 \%$ & $26,2 \%$ & $38,4 \%$ & $100 \%$ \\
\hline
\end{tabular}

Os resultados de expressão dos miRNAs 143 e 145 e dos genes ERK5, KRAS, MAP3K3 e MAP4K4 nos casos individuais estão no Anexo B. O padrão de expressão do controle endógeno $\beta 2 M$ está representando no anexo $\mathrm{C}$. 
4.2 Expressão dos miRNAs e seus genes alvo e os níveis de PSA préoperatório

A análise da expressão dos miR-143 e 145 e de seus genes alvo ERK5, KRAS, MAP3K3 e MAP4K4 de acordo com o PSA pré-operatório está demonstrada na tabela 6. Não encontramos nenhuma diferença estatística significante nesta comparação com pacientes que apresentavam PSA $>4$ $\mathrm{ng} / \mathrm{ml} \mathrm{e} \leq 4 \mathrm{ng} / \mathrm{ml}$.

Tabela 6 - Expressão dos miR-143 e 145 e seus genes alvo de acordo com o valor de PSA pré-operatório

\begin{tabular}{|c|c|c|c|}
\hline \multicolumn{4}{|c|}{ PSA (ng/ml) } \\
\hline \multicolumn{4}{|c|}{ Média / Desvio padrão } \\
\hline miRNA e Genes & $>4(n=28)$ & $\leq 4(n=16)$ & Valor de $p$ \\
\hline miR-143 & $4,34 / 9,50$ & $2,29 / 3,00$ & $0,407 * *$ \\
\hline miR-145 & $4,31 / 6,37$ & $3,37 / 3,16$ & $0,583^{*}$ \\
\hline ERK5 & $0,76 / 0,45$ & $1,08 / 0,79$ & $0,205^{*}$ \\
\hline KRAS & $2,29 / 2,12$ & $2,62 / 2,09$ & $0,613^{*}$ \\
\hline MAP3КЗ & $1,25 / 0,82$ & $114 / 0,73$ & $0,637^{*}$ \\
\hline MAP4K4 & $0,17 / 0,15$ & $0,13 / 005$ & $0,358 * *$ \\
\hline
\end{tabular}

${ }^{*}$ Teste $T{ }^{* \star}$ Teste de Mann-Whitney

\subsection{Expressão dos miRNAs e seus genes alvo e o uso de cateter vesical}

De acordo com o uso de cateter vesical não encontramos nenhuma diferença estatística significante quando comparamos a expressão dos miRNA-143 e 145 e seus genes alvo ERK5, KRAS, MAP3K3 e MAP4K4. Os dados estão demonstrados na tabela 7 
Tabela 7 - Expressão dos miR-143 e 145 e seus genes alvo de acordo com o uso de cateter vesical

\begin{tabular}{lccc}
\hline \multicolumn{4}{c}{ Catéter vesical } \\
\hline miRNA e Genes & Não $(n=23)$ & $\operatorname{Sim}(n=21)$ & Valor de $p$ \\
\hline miR-143 & $3,54 / 6,25$ & $3,66 / 9,36$ & $0,957^{* *}$ \\
miR-145 & $4,62 / 5,24$ & $3,25 / 5,62$ & $0,409^{*}$ \\
\hline ERK5 & $0,84 / 0,66$ & $0,91 / 0,56$ & $0,707^{*}$ \\
\hline KRAS & $2,82 / 2,37$ & $1,96 / 1,68$ & $0,179^{* *}$ \\
\hline MAP3K3 & $1,26 / 0,72$ & $1,15 / 0,85$ & $0,651^{*}$ \\
\hline MAP4K4 & $0,15 / 0,08$ & $0,17 / 0,16$ & $0,538^{* *}$ \\
\hline
\end{tabular}

*Teste $T$ **Teste de Mann-Whitney

\subsection{Expressão dos miRNAs e seus genes alvo e o peso da próstata na ultrassonografia}

De acordo com o peso da próstata na ultrassonografia dividido em > $60 \mathrm{~g} \mathrm{e} \leq 60 \mathrm{~g}$ não observamos diferenças estatisticamente significativas de expressão dos miRNA 143 e 145 e seus genes alvo ERK5, KRAS, MAP3K3 e MAP4K4. MAP4K4 apesar de se manter subexpresso na maioria das amostras analisadas, apresentou maior expressão em próstatas maiores ( $p$ $=0,07)$. Os dados estão demonstrados na tabela 8 . 
Tabela 8 - Expressão dos miR-143 e 145 e seus genes alvo de acordo com o peso da próstata na ultrassonografia

\begin{tabular}{lccc}
\hline \multicolumn{4}{c}{ Peso da próstata } \\
\hline miRNA e Genes & \multicolumn{3}{c}{ Média / Desvio padrão } \\
\cline { 2 - 3 }$(n=15)$ & $\leq 60 \mathrm{~g}(\mathrm{n}=29)$ & Valor de $\mathrm{p}$ \\
miR-143 & $6,59 / 12,54$ & $2,05 / 2,73$ & $0,407^{*}$ \\
miR-145 & $4,41 / 5,83$ & $374 / 5,26$ & $0,698^{*}$ \\
\hline ERK5 & $0,93 / 0,52$ & $0,85 / 0,65$ & $0,633^{*}$ \\
KRAS & $3,11 / 2,56$ & $2,05 / 1,75$ & $0,194^{*}$ \\
\hline MAP3K3 & $1,45 / 0,80$ & $1,08 / 0,75$ & $0,140^{*}$ \\
\hline MAP4K4 & $0,21 / 0,19$ & $0,13 / 0,66$ & $0,073^{*}$ \\
\hline
\end{tabular}

*Teste T

\subsection{Expressão dos miRNAs e seus genes alvo e a idade}

De acordo com a idade em que os pacientes foram divididos em $>65$ anos e $\leq 65$ anos, não encontramos diferenças estatisticamente significativas entre a expressão dos miR-143 e 145 e seus genes alvo ERK5, KRAS, MAP3K3 e MAP4K4. Os dados estão demonstrados na tabela 9. 
Tabela 9 - Expressão dos miR-143 e 145 e seus genes alvo de acordo com a idade

\begin{tabular}{|c|c|c|c|}
\hline \multicolumn{4}{|c|}{ Idade } \\
\hline \multicolumn{4}{|c|}{ Média / Desvio padrão } \\
\hline miRNA e Genes & $>65(n=21)$ & $\leq 65(n=23)$ & Valor de $p$ \\
\hline miR-143 & $5,08 / 10,8$ & $2,25 / 2,97$ & $0,916 * *$ \\
\hline miR-145 & $3,42 / 3,40$ & 4,46 / 6,79 & $0,529 *$ \\
\hline ERK5 & $0,79 / 0,54$ & $0,96 / 0,67$ & $0,360 *$ \\
\hline KRAS & $2,41 / 2,17$ & $2,41 / 2,07$ & $0,989 *$ \\
\hline МАРЗКЗ & $1,17 / 0,77$ & $1,25 / 0,81$ & $0,751^{*}$ \\
\hline MAP4K4 & $0,17 / 0,17$ & $0,15 / 0,06$ & $0,690^{*}$ \\
\hline
\end{tabular}

*Teste $T \quad$ **Teste de Mann-Whitney

\subsection{Expressão Proteica}

A análise das proteínas codificadas pelos genes KRAS, MAP3K3, ERK5 e MAP4K4 através da técnica de Western Blotting em 38 amostras de HPB estão representadas nas figuras $8,9,10$ e 11, respectivamente. A tabela 10 mostra a média de expressão das proteínas comparadas com a expressão no tecido normal, bem como a porcentagem de amostras de HPB nas quais foram expressas. A proteína KRAS esteve presente em 100\% das amostras, com média de expressão de 4312,2 (quantidade de luminescência/área) nas amostras de HPB e de 1397,1 nas amostras de tecido de próstata normal $(p=0,006)$. A proteína MAP3K3 também esteve presente em 100\% das amostras, com média de expressão de 7461,7 nas amostras de HPB e de 2726,2 nas amostras de tecido de próstata normal ( $p=0,086)$. A proteína ERK5 esteve presente em $78,94 \%$ das amostras com 
média de expressão de 3240,8 nas amostras de HPB e de 3619,4 nas amostras de tecido de próstata normal $(p=0,454)$. A proteína MAP4K4 esteve presente em $34,21 \%$ das amostras com média de expressão de 2827,3 nas amostras de HPB e de 4103,6 nas amostras de tecido de próstata normal $(p=0,041)$. A proteína estrutural $\beta$-actina foi usada para normalização, apresentando expressão homogênea entre o grupo de pacientes com HPB e o grupo de controle normal (Figura 12)( $(p=0,668)$.

A

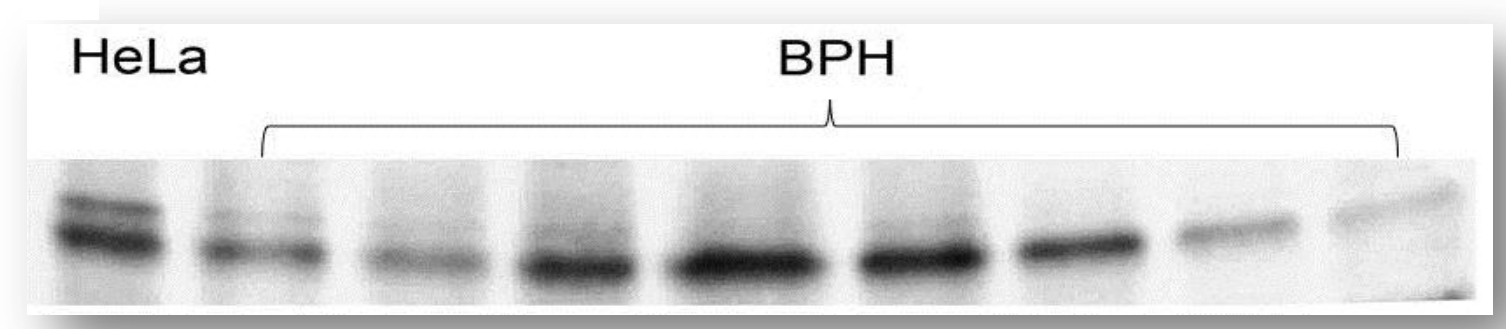

B

Figura 8 - Imagem digital da reação de Western Blotting representando a presença da proteína KRAS em amostras de HPB (A) e em tecido de próstata normal (B). Linhagem celular HeLa usada no primeiro poço como controle positivo 
A

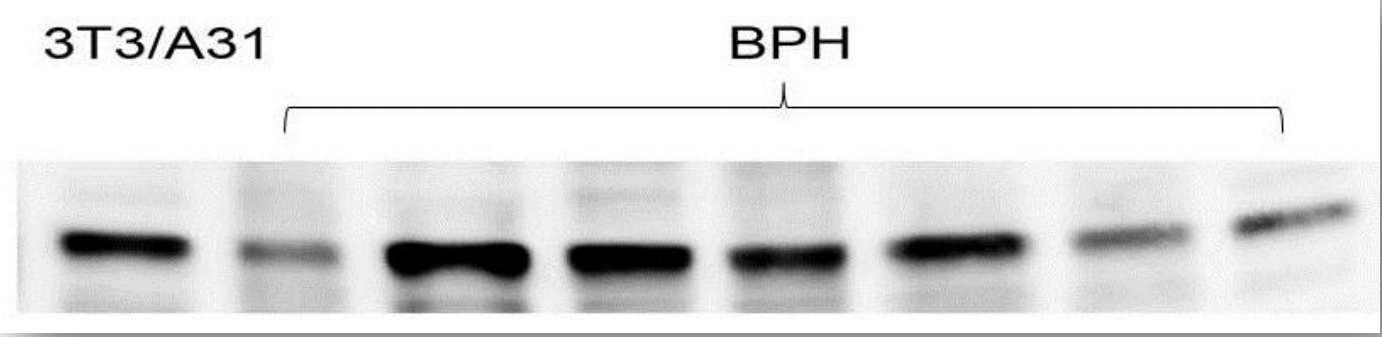

B

Figura 9 - Imagem digital da reação de Western Blotting representando a presença da proteína MAP3K3 em amostras de HPB (A) e em tecido de próstata normal (B). Linhagem celular 3T3/A31 usada no primeiro poço como controle positivo

A

HeLa

$\mathrm{BPH}$

B

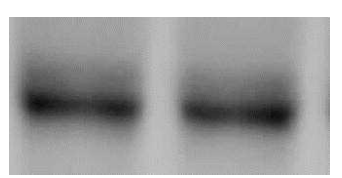

Figura 10 - Imagem digital da reação de Western Blotting representando maior ausência da proteína ERK5 em amostras de HPB $(A)$ e em tecido de próstata normal (B). Linhagem celular HeLa usada no primeiro poço como controle positivo 
A

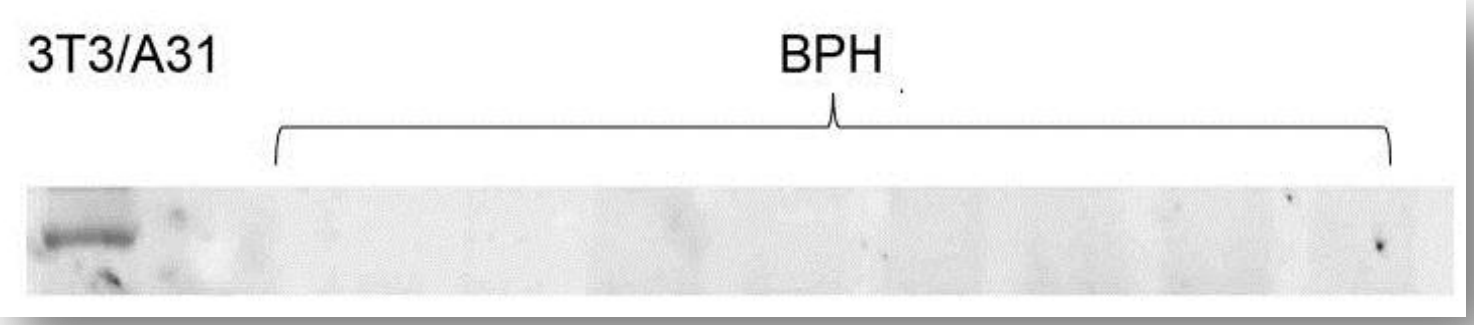

B

Figura 11 - Imagem digital da reação de Western Blotting representando a ausência da proteína MAP4K4 em amostras de HPB $(A)$ e em tecido de próstata normal (B). Linhagem celular 3T3/A31 usada no primeiro poço como controle positivo.

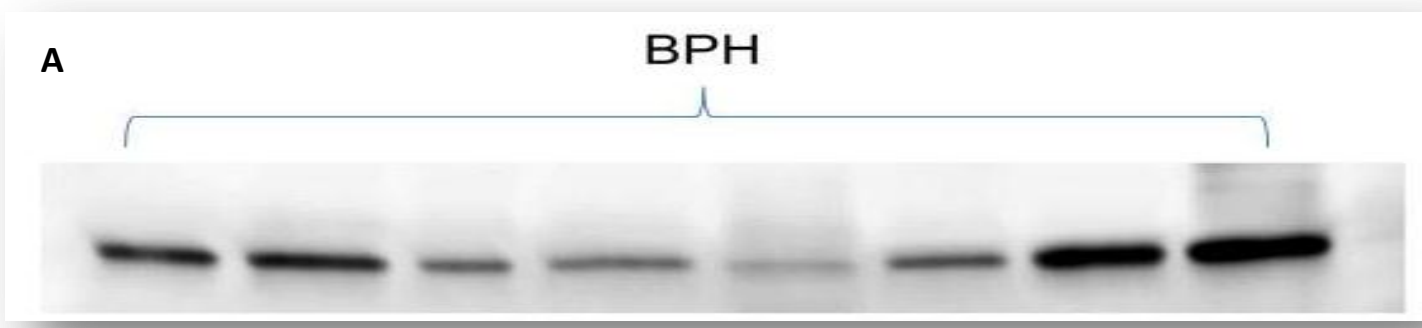

B

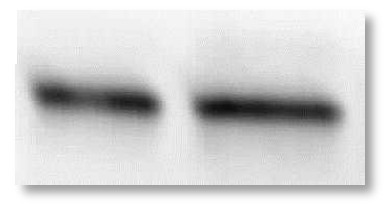

Figura 12 - Imagem digital da reação de Western Blotting representando a presença constitutiva da proteína $\beta$-actina em amostras de $\operatorname{HPB}(\mathrm{A})$ e no tecido de próstata normal $(B)$. 
Tabela 10 - Média de expressão e porcentagem de presença e ausência por Western Blotting das proteínas ERK5, KRAS, MAP3K3, MAP4K4 e $\beta$-actina estudadas em 38 pacientes com HPB

\begin{tabular}{cccccc}
\hline Western Blot & ERK5 & KRAS & MAP3K3 & MAP4K4 & $\beta$-actina \\
\hline Média (HPB) & 3240,8 & 4312,2 & 7461,7 & 2827,3 & 5752,9 \\
\hline $\begin{array}{c}\text { Média } \\
\text { (próstata } \\
\text { normal) }\end{array}$ & 3619,4 & 1397,1 & 2726,2 & 4103,6 & 5601,5 \\
\hline $\mathbf{p}$ & 0,454 & $\mathbf{0 , 0 0 6}$ & 0,086 & $\mathbf{0 , 0 4 1}$ & 0,668 \\
\hline Presença & $78,94 \%$ & $100 \%$ & $100 \%$ & $34,21 \%$ & $100 \%$ \\
Ausência & $21,06 \%$ & 0 & 0 & $65,79 \%$ & \\
\hline
\end{tabular}

Os resultados de expressão das proteínas ERK5, KRAS, MAP3K3 e MAP4K4 nos casos individuais estão no Anexo D.

\subsection{Expressão das Proteínas e os Parâmetros Clínicos dos Pacientes com HPB}

As análises da expressão das proteínas ERK5, KRAS, MAP3K3 e MAP4K4 de acordo com os parâmetros clínicos analisados, PSA préoperatório, uso de cateter vesical, peso da próstata na ultrassonografia e idade estão demonstradas nas tabelas 11, 12, 13 e 14. A única diferença estatística encontrada foi com relação à proteína ERK5 que se encontra mais expressa em pacientes com próstatas $>60$ gramas em relação às próstatas menores $(p=0,019)$. 
Tabela 11 - Expressão das proteínas de acordo com o PSA pré-operatório

\begin{tabular}{llll}
\hline \multicolumn{4}{c}{ PSA } \\
\cline { 2 - 4 } ERK5 & $\leq 4 \mathrm{ng} / \mathrm{ml} /(\mathrm{n})$ & $>4 \mathrm{ng} / \mathrm{ml} /(\mathrm{n})$ & Valor de $\mathrm{p}$ \\
KRAS & $4344,8 / \mathrm{n}=20$ & $3772,8 / \mathrm{n}=10$ & $0,406^{*}$ \\
MAP3K3 & $7055,5 / \mathrm{n}=24$ & $8157,9 / \mathrm{n}=14$ & $0,478^{*}$ \\
MAP4K4 & $2584,3 / \mathrm{n}=10$ & $3637,2 / \mathrm{n}=3$ & $0,679^{*}$ \\
\hline
\end{tabular}

Tabela 12 - Expressão das proteínas de acordo com o uso do cateter vesical

\section{Uso de cateter vesical}

\begin{tabular}{lccc}
\hline & Não $/(n)$ & $\operatorname{Sim} /(\mathrm{n})$ & Valor de $\mathrm{p}$ \\
ERK5 & $3139,9 / \mathrm{n}=13$ & $3317,9 / \mathrm{n}=17$ & $0,846^{*}$ \\
KRAS & $4189,9 / \mathrm{n}=18$ & $4422,2 / \mathrm{n}=20$ & $0,806^{*}$ \\
MAP3K3 & $6965,6 / \mathrm{n}=18$ & $7908,1 / \mathrm{n}=20$ & $0,530^{*}$ \\
MAP4K4 & $2748,9 / \mathrm{n}=8$ & $2952,6 / \mathrm{n}=5$ & $0927^{*}$ \\
\hline
\end{tabular}

*Teste $\mathrm{T}$ 
Tabela 13 - Expressão das proteínas de acordo com o peso da próstata na ultrassonografia

\begin{tabular}{|c|c|c|c|}
\hline \multicolumn{4}{|c|}{ Peso da próstata na USG } \\
\hline & $\leq 60 \mathrm{~g} /(\mathrm{n})$ & $>60 \mathrm{~g} /(\mathrm{n})$ & Valor de $p$ \\
\hline ERK5 & $1638,1 / n=9$ & $3927,7 / n=21$ & $0,019^{\star \star}$ \\
\hline KRAS & $4906,7 / n=13$ & $4003,1 / n=25$ & $0,361^{*}$ \\
\hline MAP3K3 & $7369,9 / n=13$ & $75094 / n=25$ & $0,930^{*}$ \\
\hline MAP4K4 & $3892,1 / n=5$ & $2161,8 / n=8$ & $0,427^{\star}$ \\
\hline
\end{tabular}

Tabela 14 - Expressão das proteínas de acordo com a idade

\begin{tabular}{lccc}
\hline \multicolumn{4}{c}{ Idade } \\
\hline & $\leq 65$ anos $/(n)$ & $>65$ anos $/(n)$ & Valor de $p$ \\
ERK5 & $3869,7 / n=14$ & $2690,5 / n=16$ & $0,190^{*}$ \\
KRAS & $4401,3 / n=18$ & $4232,0 / n=20$ & $0,858^{*}$ \\
MAP3K3 & $6976,3 / n=18$ & $7898,5 / n=20$ & $0,539^{*}$ \\
MAP4K4 & $2565,9 / n=7$ & $3132,3 / n=6$ & $0,792^{*}$ \\
\hline T & & &
\end{tabular}

*Teste $\overline{\mathrm{T}}$ 
5. DiscussÃo 
No presente estudo, encontramos uma superexpressão dos microRNAs (miRNAs) 143 e 145 em 62,5\% e 73,8\% dos casos, respectivamente. Até o momento a ação de miRNAs associados à HPB foi pouco explorada. Esses miRNAs já foram relatados como tendo um importante papel na morfogênese cardíaca. miR-143 foi amplamente encontrado em células-tronco embrionárias que posteriormente se diferenciaram em células cardíacas (Cordes et al., 2009). Além disso, os miR-143 e 145 tem como alvo uma série de fatores de transcrição que promovem a diferenciação e a proliferação de células musculares lisas, sendo este um dos principais motivos da nossa investigação sobre os seus possíveis papéis na HPB, visto que o estroma da próstata é basicamente formado por fibras musculares lisas associadas a tecido conjuntivo. Chagas et al. (2001) verificaram um aumento de $28,6 \%$ das fibras musculares lisas e de $33,9 \%$ no tecido conjuntivo das próstatas hiperplásicas em relação ao grupo controle. Esses dados parecem confirmar a hipótese de que a maior densidade volumétrica encontrada em HPB deve-se certamente a uma proliferação celular elevada, o que corrobora nossa suposição de que a superexpressão de ambos os miRNAs estudados pode estar sendo responsável pela proliferação celular encontrada em HPB.

Elia et al. (2009) utilizando-se de modelos animais mostrou que o knockout do miR-143 e do miR-145 resultou em alterações estruturais na aorta, devido à diferenciação incompleta de células musculares lisas da parede, sugerindo que a ausência desses miRNAs altera a manutenção deste tipo de célula. Esses miRNAs também fazem parte da modulação de 
resposta do citoesqueleto de células musculares lisas a uma lesão (Xin et al., 2009). Os camundongos com ausência de miR-143 e miR-145 não apresentaram anormalidades evidentes na diferenciação do músculo liso, embora apresentassem uma redução significativa na pressão arterial devido à redução do tônus muscular. Porém, na presença de lesão vascular, esses mesmos camundongos não apresentavam resposta à lesão, devido à desorganização das fibras de actina e atividade migratória diminuída de células musculares lisas.

Estudos no músculo cardíaco mostram que o miR-143 e o miR-145 têm a função de regular o fenótipo quiescente versus proliferativo das células musculares lisas vasculares e que miR-145 é fundamental na definição do destino do músculo liso, estando relacionado também à indução do fenótipo contrátil (Boettger et al., 2009). Sendo assim, sugerimos que esses miRNAs podem estar atuando não só no aumento da proliferação estromal no tecido prostático, mas também contribuindo para indução de fenótipo contrátil que tem sido demonstrado na HPB.

O estudo de Kent et al. (2010) demonstrou que a ativação de KRAS leva a repressão do miR-143 e do miR-145 em células humanas embrionárias, fato que não foi observado em nosso estudo, já que KRAS demonstrou superexpressão, assim como os micro RNAs em questão. Ainda neste trabalho, foi demonstrado que a perda do miR-143 e 145 é observada com frequência em câncer de pâncreas que possuem o gene KRAS mutante e que a recuperação da expressão destes miRNAs anula a tumorigênese. 
Já foi demonstrado também, que existe uma forte expressão de miR143 e miR-145 no epitélio da córnea humana, e que o miR-145 participa da regulação e formação deste epitélio, bem como da manutenção da sua integridade (Lee et al., 2011). Este é mais um exemplo de como esses micro RNAs são importantes para o desenvolvimento celular na formação de tecidos e órgãos.

Considerando os parâmetros clínicos analisados não observamos diferenças estatísticas na expressão dos miR-143 e 145. Poucos trabalhos correlacionaram níveis de expressão destes miRNA com parâmetros clínicos. Chen et al. (2010) analisando amostras de câncer de próstata e HPB, mostraram que a diminuição significativa do miR-145 foi associada com tumores de pior prognóstico. Outro estudo investigando expressão de alguns miRNA em carcinoma de células escamosas do esôfago, demonstrou que a superexpressão dos miR-143 e 145 foi associada à recidiva e metástase nos pacientes analisados (Akagi et al., 2011).

ERK5 é um membro da superfamília MAPK (Mitogen-Activated Protein Kinase) implicado na regulação de diversos processos celulares incluindo diferenciação, proliferação e sobrevida (Zhou et al., 1995; Hayashi et al., 2004; Nishimoto et al., 2006). As cascatas MAPK são vias de transdução de sinal implicadas em diversos eventos celulares, através da fosforilação. Essas cascatas são encontradas em todos os eucariotos e controlam diferentes processos como a proliferação, expressão gênica, apoptose e diferenciação (Cano et al., 1995; Cohen, 1997). ERK5 pode ser 
ativado pelos fatores de crescimento EGF e NGF (Nerve growth factor) e também por stress oxidativo e osmótico (Schaeffer et al., 1999; Kyriakis, 2001). Em nosso trabalho encontramos um subexpressão gênica de ERK5 em $59,45 \%$ dos casos. Com relação à análise proteica, ERK5 apresentou diminuição da expressão em amostras de HPB comparadas com tecido normal. Essa subexpressão gênica possivelmente se deve à superexpressão do miR-143 já que o mecanismo canônico dos miRNAs é a regulação negativa da expressão gênica em nível pós-transcripcional.

O estudo de Mehta et al. (2003), mostrou que a superexpressão da proteína ERK5 estava associada com o estímulo da proliferação no câncer de próstata. Mais recentemente, Clapé et al. (2009) mostraram que miR-143 interfere na sinalização de ERK5 e reprime a progressão do câncer de próstata em ratos. O estudo mostrou que os níveis de miR-143 são inversamente correlacionados com estágios avançados do câncer de próstata, podendo-se concluir que os efeitos desse miRNA são mediados, pela inibição da atividade de ERK5. A supexpressão de miR-143 e a diminuição da expressão de ERK5 foi correlacionada com a diminuição da proliferação celular nas linhagens celulares estudadas. Em nosso trabalho, o miR-143 pode estar mesmo suprimindo a ação de ERK5 em HPB e novos estudos in vitro devem ser feitos para comprovar essa regulação. Esses resultados são contraditórios em relação aos relatos da literatura que mostram uma superatividade de ERK5 na HPB induzido por estrógeno (Zhang et al., 2008). 
ERK5 possui aproximadamente 50 substratos, entre os quais se destacam fatores de transcrição, proteínas citoplasmáticas, além de outras quinases e fosfatases (Weinstein-Oppenheimer et al., 2000). Essa gama de substratos pode explicar as diversas funções da via ERK. Se a translocação de ERK5 ao núcleo for impedida, impossibilitará seu acesso aos fatores de transcrição e a resposta mitogênica será retardada (Brunet et al., 1999). Os diversos fatores de transcrição ativados por ERK já demonstraram estar diretamente ligados ao crescimento celular e à proliferação, por exemplo, através do aumento da expressão de ciclinas, que são reguladores positivos da progressão do ciclo celular (Gille e Downward, 1999).

Apesar da diminuição do RNAm e proteína ERK5 na maioria dos casos de hiperplasia, houve uma maior expressão proteica em próstatas > 60 gramas $(p=0019)$. ERK5 está associada à proliferação celular induzida pelos receptores tirosina quinase (Gille e Downward, 1999) e sua atividade já foi descrita no câncer de próstata e HPB (Mehta et al., 2003; Zhang et al., 2008). Nossos resultados podem demonstrar que essa via de sinalização é importante na fisiopatologia da HPB, mas ocorre mais tardiamente e é responsável por próstatas volumosas.

O gene KRAS é responsável por iniciar muitas vias de transdução de sinal em resposta a ativação dos receptores de fatores de crescimento do tipo tirosina quinase. Em nosso trabalho encontramos uma superexpressão deste gene em $79,48 \%$ das amostras, com média de expressão de 2,41 . A análise proteica mostrou a presença desta proteína em 100\% das amostras estudadas, com uma média de expressão de 4312,2 nas amostras de HPB 
contra apenas 1397,1 nas amostras de próstata normal $(p=0,006)$. Estando ambos miR-143 e KRAS superexpressos é pouco provável que miR-143 esteja controlando a expressão de KRAS nessa patologia. Por outro lado a superexpressão de KRAS pode estar envolvida na fisiopatologia da HPB (Kranenburg, 2005).

KRAS pode ser ativado em resposta a vários sinais extracelulares, entre eles destacam-se fatores de crescimento, hormônios, citocinas e neurotransmissores, que estimulam receptores tirosina quinase e receptores transmembrana ligados à proteína $G$. Os fatores de crescimento já demonstraram ter uma potente ação estimuladora sobre a proliferação das células prostáticas normais (Griffiths et al., 1993; Cohen et al., 1994; Steiner, 1995;) e esse importante grupo de peptídeos e seus receptores celulares são encontrados em maiores quantidades nas glândulas com hiperplasia do que em próstatas normais (Gregory et al., 1986; Mori et al., 1990; Steiner, 1995; Lucia et al., 2008; Neuhouser et al., 2008), e podem estar desencadeando a ativação de KRAS observada em nossos achados.

Uma das teorias relacionadas à etiopatogenia da HPB é a atividade de células inflamatórias que são um componente constantemente identificado na histologia da doença. Acredita-se que a liberação de citocinas pelas células inflamatórias promoveria a ativação de vias de sinalização celular e seriam os responsáveis finais pelo aumento da proliferação das células estromais e desenvolvimento da doença (Theyer et al., 1992). 
Podemos supor que nas nossas amostras isso esteja ocorrendo e que a superexpressão de KRAS seja um reflexo desse fenômeno.

KRAS age como uma molécula on/off. Quando ligada, recruta e ativa proteínas necessárias para a propagação de fatores de crescimento e outros receptores de sinal, como o Raf e PI3K. As consequências biológicas da ativação de PI3K incluem a proliferação, sobrevivência celular, tráfego intracelular e motilidade celular. A superexpressão de KRAS encontrada em nosso estudo poderia estar ativando a via PI3K que já foi relacionada com o aumento da proliferação e com a diminuição da apoptose em modelos animais com HPB (Jin et al., 2010).

O estudo de Yu et al. (2011) mostrou que a proliferação de células da musculatura lisa é influenciada pelo miR-let7 e sua interação com KRAS. No estudo em questão o miR-let7 foi significativamente subexpresso em células musculares lisas vasculares ao passo que KRAS demonstrou superexpressão, possivelmente pela falta de controle por parte do miR-let7, já que KRAS é alvo também desse miRNA. À semelhança deste estudo, também encontramos superexpressão deste importante gene.

Considerando os parâmetros clínicos analisados, não observamos diferenças estatísticas significantes na expressão gênica e proteica de KRAS.

Com relação ao gene MAP3K3 encontramos uma superexpressão em $61,53 \%$ dos casos analisados, com média de expressão de 1,21. A proteína MAP3K3 foi expressa em 100\% das amostras de HPB com média de 
expressão de 7461,7 , muito maior que aquela identificada nas amostras de tecido de próstata normal onde a média de expressão foi 2726,2, embora essa diferença não tenha sido significativa do ponto de vista estatístico $(p=0,086)$. Esses resultados mostram que provavelmente em HPB, este gene não esteja sendo regulado pelo miR-145. MAP3K3 é um membro da cascata MAP quinase de sinalização e é responsável por regular diretamente componentes da via ERK, porém, isso não foi observado em nosso trabalho, já que ERK5 encontra-se subexpresso em nossos casos. No entanto, a superexpressão de KRAS pode estar relacionada à superexpressão de MAP3K3 porque é um gene responsável pela ativação dos membros MAPK na via de sinalização.

Entre seus diversos papéis, MAP3K3 desempenha um papel crucial na angiogênese. Yang et al. (2000) mostrou que em ratos, a inativação do gene provocou a morte dos embriões no $11^{\circ}$ dia e mostrou uma forte perturbação no desenvolvimento dos vasos sanguíneos. A superexpressão de MAP3K3 bem como a presença do produto proteico deste gene, observada em nosso estudo, pode ser responsável pela angiogênese resultante da proliferação celular irregular que ocorre em HPB. Antagonistas de adrenoreceptores $\alpha 1$ como o prazosin são rotineiramente utilizados para o tratamento da HPB e uma de suas atividades é a inibição da angiogênese mostrando que esse é um fenômeno importante da doença talvez promovido pela atividade de MAP3K3 (Liao et al., 2011).

MAP3K3 também se mostrou superexpresso em stem cells embrionárias humanas. A expressão de MAP3K3 neste estudo se mostrou 
fortemente relacionada com a manutenção e com a diferenciação dessas células (Son et al., 2008).

Outro papel de destaque de MAP3K3 foi demonstrado por Yu et al. (2010). Este estudo feito com camundongos demonstrou que em células endoteliais com ausência de MAP3K3 não ocorre a vasculogênese.

Como mencionado anteriormente existe a possibilidade de que os quadros de HPB possam resultar de uma ação imunológica local (Theyer et al., 1992). MAPKs desempenham papéis importantes na resposta imune e regulam o desenvolvimento das células imunológicas, bem como a ativação, a diferenciação e a sobrevivência. A proteína MAP3K3 é constitutivamente expressa em linfócitos $T$ (Wang et al., 2011). Linfócitos $T$ efetores são encontrados próximos aos ductos prostáticos, e o número dessas células é seis vezes maior em homens com mais de 55 anos do que em jovens. Isso pode indicar que com o passar dos anos, surge na próstata um fenômeno autoimune gerado por algum antígeno específico local ainda não identificado (Theyer et al., 1992; Griffiths et al., 1993; Kramer et al., 2007). Como resultado, o microambiente que circunda as células epiteliais da próstata seria inundado por linfocinas. Essas linfocinas produzidas pelas células inflamatórias poderiam influenciar a produção local de fatores de crescimento e a angiogênese no tecido prostático (Lucia et al., 2008). Sendo assim a superexpressão de MAP3K3 em linfócitos $T$ poderia estar contribuindo para este processo, bem como para a indução da angiogênese. Em conformidade com estes achados, encontramos superexpressão da 
proteína MAP3K3, quase três vezes maior nas nossas amostras de HPB em relação ao tecido normal embora essa diferença não tenha sido significante.

Craig et al. (2010) demonstraram que no desenvolvimento do coração a ativação da proteína MAP3K3 é fundamental para que ocorra a formação do sistema de vasos coronários e também para que ocorra uma série de mudanças morfológicas e fisiológicas conhecidas como a transformação do epitélio mesenquimal que dará origem a diferentes componentes celulares da vasculatura coronária.

De acordo com os parâmetros clínicos analisados, não encontramos diferenças estatísticas significativas com relação à expressão gênica e proteica de MAP3K3.

Outro membro da família das MAPKs estudados em nosso trabalho foi o gene MAP4K4. Este apresentou subexpressão gênica em todas as amostras analisadas, com média de expressão de 0,16. Também houve, uma ausência de expressão da proteína MAP4K4 em 65,79\% das nossas amostras com uma média de expressão de 2827,3 em HPB enquanto nas amostras de tecido prostático normal foi de 4103,6 ( $p=0,041)$. A superexpressão de miR-145 e a subexpressão de MAP4K4 sugere o controle da expressão desse gene pelo miRNA. Guntur et al. (2010) demonstrou que MAP4K4 é responsável pela regulação negativa da via de mTOR (Mammalian target of rapamycin) via controle pós-transcripcional de PPARY. mTOR desempenha um papel central em vários processos celulares sendo importante na sobrevivência celular incluindo a da 
musculatura lisa. Podemos inferir que a subexpressão de MAP4K4, neste caso controlada por miR-145, pode deixar de regular negativamente mTOR o que resultaria em uma proliferação e sobrevivência celular irregulares resultando a HPB.

Por outro lado, MAP4K4 tem sido descrito como superexpresso em muitos tipos de câncer humano onde desempenha um papel importante na transformação, invasão, adesão e migração celular, como é o caso do carcinoma hepatocelular (Liu et al., 2011), no adenocarcinoma de pâncreas (Liang et al., 2008) e também no câncer colorretal (Hao et al., 2010). Em contraste sua subexpressão também já foi relacionada com o desenvolvimento ósseo, motilidade celular e regulação da transcrição (Palmieri et al., 2008).

Considerando os parâmetros clínicos analisados, não observamos diferenças estatísticas significantes nos níveis gênico e proteico de MAP4K4.

Consideramos a ausência de correlação estatística entre a expressão gênica e proteica da maioria dos genes com os parâmetros clínicos analisados, um ponto positivo de nosso trabalho, já que neste caso todos os pacientes analisados apresentavam HPB. Com a futura confirmação do papel importante que os miRNAs em questão e de seus genes alvo podem estar desempenhando na HPB, estas moléculas poderão ser consideradas marcadores homogêneos na doença, não apresentando variações em diferentes grupos. 
Acreditamos que os miR-143 e miR-145 podem estar envolvidos na etiopatogenia da HPB alterando a homeostase principalmente do tecido fibromuscular, controlando proliferação e diferenciação e interferindo na expressão de ERK5 e MAP4K4. Os genes KRAS e MAP3K3 parecem não estar sendo regulados pelos miR-143 e 145 na HPB e podem estar envolvidos em importantes eventos responsáveis pelo desenvolvimento da doença, iniciando importantes vias de sinalização, resultando em aumento da proliferação, sobrevivência celular, tráfego intracelular e angiogênese.

A etiopatogenia da HPB ainda não foi completamente compreendida e esse estudo inédito nos permite afirmar que a alteração da expressão de miRNA pode estar envolvida no desenvolvimento da doença. Estudos adicionais com outros miRNAs podem vir a trazer informações importantes para o entendimento da doença e possível sugestão de novas terapias.

\subsection{Perspectivas}

Como planejamento futuro, entendemos que ensaios in vitro também serão necessários para comprovar a ação dos miRNA sobre seus genes alvo. Nestes ensaios, a expressão gênica dos miRNAs pode ser inibida ou estimulada, e desta forma, através de análises funcionais, as hipóteses levantadas no presente estudo podem ser confirmadas. 
6. Conclusões 
As diferenças de expressão dos miRNAs estudados e seus genes e proteínas alvo entre pacientes com e sem HPB sugerem sua participação na etiopatogenia da doença.

O miR-143 encontra-se superexpresso em pacientes com HPB e parece controlar a expressão de ERK5. KRAS encontra-se superexpresso em pacientes com HPB.

O miR-145 encontra-se superexpresso em pacientes com HPB e parece controlar a expressão de MAP4K4. MAP3K3 encontra-se superexpresso em pacientes com HPB.

Considerando os parâmetros clínicos, a proteína ERK5 apresentou maior expressão em próstatas maiores. 
7. ANEXos 
Anexo A - Termo de consentimento livre e esclarecido

HOSPITAL DAS CLÍNICAS DA FACULDADE DE MEDICINA DA UNIVERSIDADE DE SÃO PAULO-HCFMUSP

MODELO DE TERMO DE CONSENTIMENTO LIVRE E ESCLARECIDO

DADOS DE IDENTIFICAÇÃO DO SUJEITO DA PESQUISA OU RESPONSÁVEL LEGAL

1. NOME:

DOCUMENTO DE IDENTIDADE № : SEXO : .M $\square \quad F$

DATA NASCIMENTO:

ENDEREÇO № APTO:

BAIRRO: CIDADE CEP: TELEFONE:

DDD

$(\ldots \ldots \ldots \ldots .$.

2.RESPONSÁVEL

LEGAL $\begin{array}{lllll} & \text { (grau } & \text { de } & \text { parentesco, } & \text { tutor, }\end{array}$ DOCUMENTO DE IDENTIDADE SEXO: $M \square \quad F \square$ DATA NASCIMENTO.: ...................... ENDEREÇO: № APTO: BAIRRO: CIDADE: CEP: TELEFONE: DDD

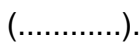

\section{DADOS SOBRE A PESQUISA}

TÍTULO DO PROTOCOLO DE PESQUISA: O papel dos micro RNA 143 e 145 e seus genes alvo na fisiopatologia da hiperplasia benigna da próstata PESQUISADOR: Dr. Alberto Azoubel Antunes CARGO/FUNÇÃO: Médico, Pesquisador do Laboratório de Investigação Médica da Disciplina de Urologia LIM/55

INSCRIÇÃO CONSELHO REGIONAL: No 113877

UNIDADE DO HCFMUSP: Departamento de cirurgia, disciplina de urologia.

1. AVALIAÇÃO DO RISCO DA PESQUISA: 


$\begin{array}{lll}\text { RISCO MÍNIMO } & \square & \text { RISCO MÉDIO } \\ \text { RISCO BAIXO } & X & \text { RISCO MAIOR }\end{array}$

\section{DURAÇÃO DA PESQUISA: 24 meses}

O objetivo desse estudo é avaliar se existe uma relação entre a ação de marcadores moleculares e o crescimento de sua próstata

O trabalho será realizado utilizando parte do tecido que foi retirado durante a sua cirurgia, não acarretará nenhum prejuízo a sua pessoa ou ao próprio material que continuará preservado para seu interesse futuro.

Não será necessário fazer nenhum procedimento adicional, apenas o seu tratamento convencional.

Portanto esta pesquisa não the traz nenhum desconforto e nenhum risco. Os riscos são os mesmos de sua cirurgia para tratamento da hiperplasia prostática benigna, lembrando que não será feito nada para 0 senhor além do necessário para o tratamento. Não há benefício direto para o senhor, somente no final do estudo poderemos concluir a presença de algum benefício para os pacientes, como por exemplo, a compreensão dos mecanismos responsáveis pelo crescimento de sua próstata e talvez até um novo tratamento.

Como não há procedimentos adicionais a serem feitos, não existem procedimentos alternativos.

Garantia de acesso: em qualquer etapa do estudo, você terá acesso aos profissionais responsáveis pela pesquisa para esclarecimento de eventuais dúvidas. O principal investigador é a Dr. Alberto Azoubel Antunes, que pode ser encontrado no endereço Av. Dr. Enéas de Carvalho Aguiar 255- $7^{\circ}$ andar sala 710-F, Telefone (011) 3069 - 8080. Se você tiver alguma consideração ou dúvida sobre a ética da pesquisa, entre em contato com o Comitê de Ética em Pesquisa (CEP) - Rua Ovídio Pires de Campos, 225 - 5o andar - tel: 3069-6442 ramais $16,17,18$ ou 20, FAX: 3069-6442 ramal 26 - E-mail: cappesq@hcnet.usp.br

É garantida a liberdade da retirada de consentimento a qualquer momento e deixar de participar do estudo, sem qualquer prejuízo à continuidade de seu tratamento na Instituição; Direito de confidencialidade - As informações obtidas serão analisadas em conjunto com outros pacientes, não sendo divulgada a identificação de nenhum paciente; Direito de ser mantido atualizado sobre os resultados parciais das pesquisas, quando em estudos abertos, ou de resultados que sejam do conhecimento dos pesquisadores; Despesas e compensações: não há despesas pessoais para o participante em qualquer fase do estudo, incluindo exames e consultas. Também não há compensação financeira 
relacionada à sua participação. Se existir qualquer despesa adicional, ela será absorvida pelo orçamento da pesquisa. Compromisso do pesquisador de utilizar os dados e o material coletado somente para esta pesquisa.

Acredito ter sido suficientemente informado a respeito das informações que li ou que foram lidas para mim, descrevendo o estudo: "O papel dos micro RNA 143 e 145 e seus genes alvo na fisiopatologia da hiperplasia benigna da próstata". Eu discuti com o Dr. Alberto Azoubel Antunes sobre a minha decisão em participar nesse estudo. Ficaram claros para mim quais são os propósitos do estudo, os procedimentos a serem realizados, seus desconfortos e riscos, as garantias de confidencialidade e de esclarecimentos permanentes. Ficou claro também que minha participação é isenta de despesas e que tenho garantia do acesso a tratamento hospitalar quando necessário. Concordo voluntariamente em participar deste estudo e poderei retirar o meu consentimento a qualquer momento, antes ou durante o mesmo, sem penalidades ou prejuízo ou perda de qualquer benefício que eu possa ter adquirido, ou no meu atendimento neste Serviço.

Assinatura do paciente/representante legal

Data 11

Assinatura da testemunha

Data

Para casos de pacientes menores de 18 anos, analfabetos, semianalfabetos ou portadores de deficiência auditiva ou visual.

Declaro que obtive de forma apropriada e voluntária o Consentimento Livre e Esclarecido deste paciente ou representante legal para a participação neste estudo.

Dr. Alberto Azoubel Antunes

Data 11 
Anexo B - Tabela com características demográficas de todos os pacientes e a expressão obtida na análise do miR143 e 145 e dos genes ERK5, KRAS, MAP3K3 e MAP4K4

\begin{tabular}{|c|c|c|c|c|c|c|c|c|c|c|}
\hline Caso & Idade & $\begin{array}{l}\text { Psa- } \\
\text { pré }\end{array}$ & Sonda & $\begin{array}{l}\text { Peso } \\
\text { USG }\end{array}$ & miR143 & miR145 & ERK5 & KRAS & MAP3K3 & MAP4K4 \\
\hline $\mathrm{H} 7$ & 71 & 1,5 & Não & 39 & 0,318 & 2,824 & 0,723 & 2,487 & 1,469 & 0,156 \\
\hline $\mathrm{H} 8$ & 65 & 2,5 & Sim & 50 & 1,380 & 2,600 & 0,939 & 2,348 & 1,196 & 0,171 \\
\hline H9 & 60 & 2,3 & Não & 31 & 5,059 & 12,13 & 1,150 & 7,425 & 2,312 & 0,420 \\
\hline $\mathrm{H} 10$ & 47 & 6,9 & Sim & 56 & 0,284 & 2,604 & 0,833 & 3,049 & 0,588 & 0,129 \\
\hline $\mathrm{H} 11$ & 77 & 1,2 & Não & 34 & 9,215 & 22,56 & 1,200 & 7,618 & 1,078 & 0,243 \\
\hline $\mathrm{H} 12$ & 68 & 2,3 & Não & 53 & 1,013 & 4,675 & 1,211 & 3,209 & 0,724 & 0,239 \\
\hline $\mathrm{H} 13$ & 61 & 5,6 & Sim & 200 & 0,199 & 1,931 & 0,025 & 0,001 & 0,175 & 0,090 \\
\hline $\mathrm{H} 14$ & 63 & 1,2 & Não & 25 & 0,306 & 1,765 & 0,657 & 1,721 & 0,896 & 0,106 \\
\hline $\mathrm{H} 15$ & 62 & 7,2 & Sim & 45 & 0,952 & 2,615 & 1,402 & 5,057 & 1,358 & 0,222 \\
\hline $\mathrm{H} 16$ & 52 & 1 & Não & 24 & 29,46 & 6,708 & 1,710 & 7,172 & 3,047 & 0,154 \\
\hline $\mathrm{H} 17$ & 59 & 30,2 & Sim & 104 & 2,109 & 0,097 & 1,390 & 5,250 & 1,794 & 0,114 \\
\hline $\mathrm{H} 18$ & 64 & 8,9 & Sim & 154 & 9,056 & 9,253 & 0,035 & 0,950 & 0,429 & 0,080 \\
\hline $\mathrm{H} 19$ & 72 & 3,9 & Não & 55 & 0,723 & 1,254 & 0,725 & 1,770 & 0,634 & 0,062 \\
\hline $\mathrm{H} 2 \mathrm{O}$ & 69 & 2,1 & Não & 72 & 6,302 & 7,285 & 2,075 & 7,838 & 2,035 & 0,165 \\
\hline $\mathrm{H} 21$ & 63 & 5,6 & Sim & 117 & 1,030 & 3,033 & 0,914 & 2,235 & 1,116 & 0,082 \\
\hline H22 & 71 & 11,8 & Não & 53 & 0,845 & 0,699 & 0,059 & 1,535 & 0,042 & 0,097 \\
\hline $\mathrm{H} 23$ & 60 & 5,2 & Não & 113 & 2,057 & 3,858 & 0,739 & 2,480 & 1,393 & 0,081 \\
\hline $\mathrm{H} 24$ & 77 & 0,7 & Não & 56 & 2,130 & 3,693 & 1,061 & 3,329 & 2,596 & 0,190 \\
\hline $\mathrm{H} 25$ & 58 & 10 & Sim & 34 & 0,345 & 1,243 & 2,120 & 3,196 & 1,267 & 0,163 \\
\hline H26 & 76 & 4,5 & Não & 56 & 1,907 & 4,257 & 0,589 & 1,570 & 1,309 & 0,090 \\
\hline H27 & 78 & 2,3 & Não & 74 & 8,994 & 10,93 & 2,174 & 2,968 & 1,490 & 0,145 \\
\hline H28 & 78 & 11,3 & Sim & 109 & 8,730 & 26,19 & 1,026 & 5,178 & 3,775 & 0,279 \\
\hline H29 & 58 & 0,8 & Não & 56 & 4,132 & 10,34 & 0,820 & 2,058 & 1,334 & 0,095 \\
\hline $\mathrm{H} 30$ & 59 & 3,1 & Sim & 125 & 1,310 & 2,803 & 0,848 & 1,841 & 1,734 & 0,272 \\
\hline $\mathrm{H} 46$ & 70 & 0,3 & Não & 33 & 1,885 & 2,360 & 0,080 & 0,959 & 0,886 & 0,108 \\
\hline $\mathrm{H} 47$ & 88 & 1,4 & Não & 51 & 1,288 & 2,199 & 0,232 & 1,505 & 1,331 & 0,128 \\
\hline $\mathrm{H} 48$ & 62 & 0,8 & Sim & 72 & 1,837 & 1,882 & 0,127 & 0,406 & 0,537 & 0,047 \\
\hline $\mathrm{H} 49$ & 50 & 3,7 & Não & 38 & 3,482 & 2,347 & 0,320 & 1,296 & 0,731 & 0,031 \\
\hline $\mathrm{H} 50$ & 83 & 4,2 & Sim & 45 & 0,638 & 0,500 & 0,818 & 1,538 & 1,358 & 0,138 \\
\hline H51 & 75 & 3,9 & Sim & 76 & 0,639 & 0,961 & 0,530 & 0,472 & 0,781 & 0,130 \\
\hline H52 & 55 & 0,8 & Sim & 22 & 43,05 & 4,213 & 2,020 & 3,886 & 2,731 & 0,841 \\
\hline H53 & 57 & 8,2 & Sim & 56 & 0,338 & 0,511 & 0,679 & 0,656 & 0,597 & 0,102 \\
\hline $\mathrm{H} 54$ & 69 & 3,4 & Sim & 54 & 3,264 & 0,378 & 0,432 & 0,273 & 0,558 & 0,129 \\
\hline $\mathrm{H} 55$ & 67 & 1,0 & Sim & 79 & 0,525 & 0,318 & 0,868 & 1,388 & 0,543 & 0,100 \\
\hline H56 & 84 & 1,0 & Sim & 36 & 0,569 & 0,736 & 0,538 & 0,346 & 0,434 & 0,131 \\
\hline $\mathrm{H} 57$ & 65 & 6,4 & Sim & 67 & 0,253 & 2,559 & 1,097 & 1,273 & 0,798 & 0,139 \\
\hline H58 & 72 & 1,0 & Não & 31 & 1,101 & 3,986 & 2,235 & 3,192 & 1,746 & 0,258 \\
\hline H59 & 67 & 2,6 & Sim & 24 & 0,167 & 0,572 & 1,090 & 0,772 & 0,813 & 0,111 \\
\hline $\mathrm{H} 60$ & 69 & 10,2 & Sim & 104 & 0,370 & 3,384 & 1,521 & 1,196 & 1,746 & 0,208 \\
\hline H88 & 58 & 1,5 & Não & 50 & 0,093 & 0,122 & 0,252 & 0,508 & 0,649 & 0,127 \\
\hline $\mathrm{H} 90$ & 58 & 8,6 & Não & 48 & 0,067 & 0,125 & 0,284 & 0,569 & 0,629 & 0,128 \\
\hline H93 & 46 & 3,4 & Não & 36 & 0,232 & 0,433 & 0,352 & 0,616 & 0,640 & 0,154 \\
\hline $\mathrm{H} 94$ & 75 & 3,3 & Não & 171 & 0,482 & 1,241 & 0,201 & 0,456 & 0,498 & 0,053 \\
\hline H96 & 72 & 2,9 & Não & 63 & 0,334 & 0,543 & 0,608 & 2,632 & 1,678 & 0,241 \\
\hline
\end{tabular}


Anexo C - Padrão de expressão do controle endógeno $\beta 2 \mathrm{M}$.

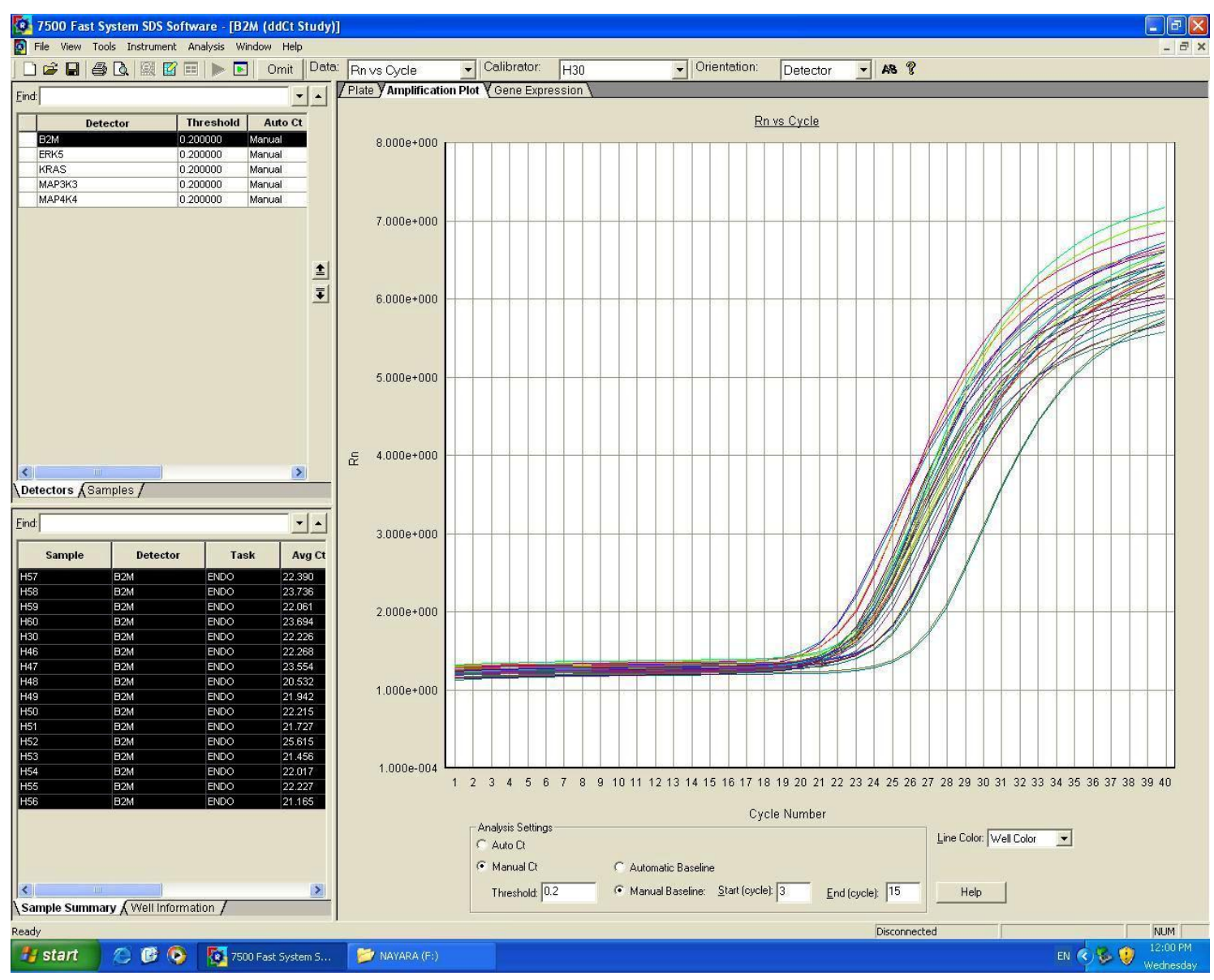


Anexo D - Expressão das proteínas ERK5, KRAS, MAP3K3, MAP4K4 e $\beta$ actina nas amostras de HPB e em tecido de próstata normal.

\begin{tabular}{|c|c|c|c|c|c|}
\hline Caso & ERK5 & KRAS & MAP3K3 & MAP4K4 & B -actina \\
\hline $\mathrm{H} 7$ & 56925 & 534424 & 314100 & 1293498 & 143477 \\
\hline $\mathrm{H} 8$ & 298009 & 187973 & 361282 & 299689 & 830789 \\
\hline $\mathrm{H} 9$ & 119185 & 520405 & 856283 & 157791 & 438908 \\
\hline $\mathrm{H} 11$ & 123788 & 1217191 & 1272966 & & 1288405 \\
\hline $\mathrm{H} 12$ & 89306 & 501841 & 1230515 & & 852867 \\
\hline $\mathrm{H} 13$ & 69026 & 791351 & 762138 & 186948 & 377505 \\
\hline $\mathrm{H} 14$ & & 425744 & 690220 & & 922427 \\
\hline $\mathrm{H} 15$ & & 581840 & 833419 & & 1169655 \\
\hline $\mathrm{H} 16$ & & 193818 & 547578 & & 168281 \\
\hline $\mathrm{H} 17$ & & 559179 & 785768 & & 150015 \\
\hline $\mathrm{H} 18$ & 1021115 & 1014156 & 148655 & 826064 & 244516 \\
\hline $\mathrm{H} 19$ & 442195 & 214754 & 707736 & 157402 & 1244981 \\
\hline $\mathrm{H} 2 \mathrm{O}$ & 411590 & 242891 & 1344337 & & 467889 \\
\hline $\mathrm{H} 21$ & 366864 & 283763 & 1175465 & & 57800 \\
\hline $\mathrm{H} 22$ & & 351198 & 657700 & & 675225 \\
\hline $\mathrm{H} 25$ & & 113198 & 1203395 & & 198862 \\
\hline $\mathrm{H} 26$ & & 446590 & 292325 & 155227 & 833587 \\
\hline $\mathrm{H} 27$ & 246989 & 765987 & 959702 & & 52092 \\
\hline $\mathrm{H} 28$ & 313993 & 621139 & 1560563 & & 380234 \\
\hline $\mathrm{H} 29$ & 604943 & 180041 & 1094054 & & 346893 \\
\hline $\mathrm{H} 30$ & 407248 & 202553 & 244318 & & 126008 \\
\hline $\mathrm{H} 46$ & & 559179 & 150900 & & 596205 \\
\hline $\mathrm{H} 47$ & 90704 & 550973 & 1344337 & 127280 & 747099 \\
\hline $\mathrm{H} 48$ & 224990 & 183624 & 1175465 & & 291160 \\
\hline $\mathrm{H} 49$ & 306226 & 304471 & 657700 & & 371910 \\
\hline $\mathrm{H} 50$ & 122766 & 261236 & 1203395 & & 237345 \\
\hline H51 & 150189 & 591895 & 959702 & & 393351 \\
\hline H52 & 140926 & 903946 & 1560563 & & 997304 \\
\hline H53 & 128700 & 1019612 & 1094054 & & 1245453 \\
\hline H54 & 179519 & 391185 & 856283 & & 47632 \\
\hline H55 & 107925 & 191826 & 1034188 & & 523327 \\
\hline H56 & 638513 & 534424 & 150900 & & 277488 \\
\hline H57 & 817173 & 152145 & 366949 & 95816 & 1087480 \\
\hline H58 & 676793 & 114549 & 214170 & 78154 & 1144665 \\
\hline H59 & 156318 & 96598 & 172882 & 67823 & 948201 \\
\hline $\mathrm{H} 60$ & 497322 & 162934 & 167012 & & 915707 \\
\hline H88 & 487553 & 231230 & 122502 & 86830 & 562345 \\
\hline $\mathrm{H} 9 \mathrm{O}$ & 425734 & 186611 & 80992 & 143016 & 504087 \\
\hline $\mathrm{N} 1$ & 381239 & 133192 & 238620 & 418651 & 511710 \\
\hline N2 & 342648 & 146233 & 306631 & 402073 & 608598 \\
\hline
\end{tabular}


8. REFERÊNCIAS BiBLIOGRÁFICAS 
Akagi I, Miyashita M, Ishibashi O, Mishima T, Kikuchi K, Makino H, Nomura T, Hagiwara N, Uchida E, Takizawa T. Relationship between altered expression levels of MIR21, MIR143, MIR145, and MIR205 and clinicopathologic features of esophageal squamous cell carcinoma. Dis Esophagus. 2011;24(7):523-30.

Akao Y, Nakagawa Y, Naoe T. MicroRNAs 143 and 145 are possible common onco-microRNAs in human cancers. Oncol Rep. 2006;16(4):845-50.

Akdogan M, Hassoun BS, Gurakar A, El-Sahwi K, Jazzar A, Wright H, Sebastian A, Nour B. Prostate-specific antigen levels among cirrhotic patients. Int J Biol Markers. 2002;17(3):161-4.

Ambros V. The functions of animal microRNAs. Nature. 2004;431:350-355.

Antunes AA, Dall'Oglio M, Srougi M. Etiopatogenia da Hiperplasia Prostática Benigna. In: Srougi M, Antunes AA, Dall'Oglio M, editores. Hiperplasia Prostática Benigna. 1a ed. São Paulo: Atheneu; 2010. p.13-23.

Antunes AA, Srougi M, Dall'oglio MF, Vicentini F, Paranhos M, Freire GC. The Role of BHP, lower urinary tract symptons, and PSA levels on erectile function of brazilian MSN Who undergo prostate cancer screening. J Sex Med. 2008;5(7):1702-7.

Barry MJ. Evaluation of symptoms and quality of life in men with benign prostatic hyperplasia. Urology. 2001;58(1):25-32. 
Barstch G, Muller HR, Oberholzer M, Rohr HP. Light microscopic stereological analysis of the normal human prostate and of benign prostatic hyperplasia. J Urol. 1979;122:487-91.

Bartel DP. MicroRNAs: Genomics, Biogenesis, Mechanism, and Function. Cell. 2004;116(2):281-297.

Bhargava S, Canda AE, Chapple CR. A rational approach to benign prostatic hyperplasia evaluation: recent advances. Curr Opin Urol. 2004;14:1-6.

Bianchi-Frias D, Vakar-Lopez F, Coleman IM, Plymate SR, Reed MJ, Nelson PS. The effects of aging on the molecular and cellular composition of the prostate microenvironment. PLoS One. 2010; 5(9):12501-12517.

Billis A. Uropatologia da Próstata. $1^{\text {a }}$ ed. Goiânia: Editora Universidade Federal de Goiânia; 1997.

Boettger T, Beetz N, Kostin S, Schneider J, Krüger M, Hein L, Braun T. Acquisition of the contractile phenotype by murine arterial smooth muscle cells depends on the Mir143/145 gene cluster. J Clin Invest. 2009;119:263444.

Bosch JL, Hop WC, Niemer AQ, Bangma CH, Kirkels WJ, Schroder FH. Parameters of prostate volume and shape in a community based population of men 55 to 74 years old. J Urol. 1994;152(5 Pt 1):1501-5.

Bruchovsky N, Lieskovsky G. Increased ratio of 5 alpha-reductase: 3 alpha (beta)-hydroxysteroid dehydrogenase activities in the hyperplastic human prostate. J Endocrinol. 1979;80(3):289-301. 
Brunet A, Roux D, Lenormand P, Dowd S, Keyse S, Pouysségur J. Nuclear translocation of p42/p44 mitogen-activated protein kinase is required for growth factor-induced gene expression and cell cycle entry. EMBO J. 1999;18(3):664-74.

Calin GA, Sevignani C, Dunitru CD, Hyslop T, Noch E, Yendamuri S, Shimizu M, Rattan S, Bullrich F, Negrini M, Croce CM. Human microRNA genes are frequently located at fragile sites and genomic regions involved in cancers. PNAS. 2004;101(9):2999-3004.

Cano E, Hazzalin CA, Kardalinou E, Buckle RS, Mahadevan LC. Neither ERK nor JNK/SAPK MAP kinase subtypes are essential for histone H3/HMG14 phosphorylation or c-fos and c-jun induction. $J$ Cell Sci. 1995;108(11):3599-609.

Cardoso ICRA, Benfica MGA, Chamone CB, Castro GF, Peixoto KB. Utilização do antígeno prostático específico (PSA livre/total), como marcador tumoral no diagnóstico de câncer de próstata e hiperplasia benigna prostática. Rev Bras Anal Clin. 2000;32(1):3-6.

Carmell MA, Hannon GJ. RNase III enzymes and the initiation of gene silencing. Nat Struct Mol Biol. 2004;11(3):214-8.

Chagas MA, Babinski MA, Costa WS, Sampaio FJB. Stereological analysis of histologic components in transition zone of normal and hyperplastic human prostates. Braz J Urol. 2001;27:26-31. 
Chen CZ. MicroRNAs as oncogenes and tumor suppressors. New Engl $J$ Med. 2005;353:1768-1771.

Chen JF, Callis TE, Wang DZ. microRNAs and muscle disorders. J Cell Sci. 2009;122: 13-20.

Chen X, Gong J, Zeng H, Chen N, Huang R, Huang Y, Nie L, Xu M, Xia J, Zhao F, Meng W, Zhou Q. MicroRNA145 targets BNIP3 and suppresses prostate cancer progression. Cancer Res. 2010;70(7):2728-38.

Clapé C, Fritz V, Henriquet C, Apparailly F, Fernandez PL, Iborra F, Avancès C, Villalba M, Culine S, Fajas L. miR-143 interferes with ERK5 signaling, and abrogates prostate cancer progression in mice. PLOS One. 2009;4(10):e7542.

Coffey DS, Walsh PC. Clinical and experimental studies of benign prostatic hyperplasia. Urol Clin North Am. 1990;17(3):461-75.

Cohen DW, Simak R, Fair WR, Melamed J, Scher HI, Cordon-Cardo C. Expression of transforming growth factor-alpha and the epidermal growth factor receptor in human prostate tissues. J Urol. 1994;52(6 Pt 1):2120-4.

Cohen P. The search for physiological substrates of MAP and SAP kinases in mammalian cells. Trends Cell Biol. 1997;7(9):353-61.

Condorelli G, Dimmeler S. MicroRNAs: Components of an integrated system controlling cardiac development, physiology, and disease pathogenesis. Cardiovasc Res. 2008;79:551-552. 
Cordes KR, Sheehy NT, White MP, Berry EC, Morton SU, Muth AN, Lee TH, Miano JM, Ivey KN, Srivastava D. miR-145 and miR-143 regulate smooth muscle cell fate and plasticity. Nature. 2009;460:705-10.

Craig EA, Austin AF, Vaillancourt RR, Barnett JV, Camenisch TD. TGFß2mediated production of hyaluronan is important for the induction of epicardial cell differentiation and invasion. Exp Cell Res. 2010;316(20):3397-405.

Dalmay T. MicroRNAs and cancer. J Intern Med. 2008;263:366-75.

Deering RE, Choongkittaworn M, Bigler SA, Aramburu E, King J, Brawer, MK. Morphometric quantitation of stroma in human benign prostatic hyperplasia. Urology. 1994;44:64-70.

De Marzo AM, Marchi VL, Epstein JI, Nelson WG. Proliferative inflammatory atrophy of the prostate: implications for prostatic carcinogenesis. Am J Pathol. 1999;155:1985-92.

Díaz ER, Corona JS, Gómez RCR, Rubio SAG, Camacho JGV, Moreno HS, Moguel MCM. Angiotensin-converting enzyme insertion/deletion and angiotensin type 1 receptor $\mathrm{A} 1166 \mathrm{C}$ polymorphisms as genetic risk factors in benign prostatic hyperplasia and prostate cancer. Journal of ReninAngiotensin-Aldosterone System. 2009;10(4):241-46.

Dip, NG. Análise de Expressão de Micro RNA em Carcinoma Urotelial de Bexiga. Data de defesa: 27/07/2012. 133p. Tese Doutorado - Faculdade de Medicina da Universidade de São Paulo. São Paulo, 2012. 
Elia L, Quintavalle M, Zhang J, Contu R, Cossu L, Latronico MV, Peterson KL, Indolfi C, Catalucci D, Chen J, Courtneidge SA, Condorelli G. The knockout of miR-143 and -145 alters smooth muscle cell maintenance and vascular homeostasis in mice: correlates with human disease. Cell Death Differ. 2009;16(12):1590-8.

Faber $\mathrm{C}$, Kirchner T, Hlubek $\mathrm{F}$. The impact of microRNAs on colorectal cancer. Virchows Arch. 2009;454(4):359-67.

Franco-Salinas G, de la Rosette JJMHC, Michel MC. Pharmacokinetics and Pharmacodynamics of Tamsulosin in its Modified-Release and Oral Controlled Absorption System Formulations. Clin Pharmacokinet. 2010;49(3):177-88.

Franks LM. Atrophy and hyperplasia in the prostate proper. J Pathol Bacterol. 1954;68(2):617-21.

Gille H, Downward J. Multiple ras effector pathways contribute to $G(1)$ cell cycle progression. J Biol Chem. 1999;274(31):22033-40.

Glynn RJ, Campion EW, Bouchard GR, Silbert JE. The development of benign prostatic hyperplasia among volunteers in the Normative Aging Study. Am J Epidemiol. 1985;121(1):78-90.

Gormley GJ, Stoner E, Bruskewitz RC, Imperato-McGinley J, Walsh PC, McConnell JD, Andriole GL, Geller J, Bracken BR, Tenover JS, Vaughan ED, Pappas F, Taylor A, Binkowitz B, Ng J. The effect of finasteride in men with benign prostatic hyperplasia. New Engl J Med. 1992;327(17):1185-91. 
Gregory H, Willshire IR, Kavanagh JP, Blacklock NJ, Chowdury S, Richards RC. Urogastrone-epidermal growth factor concentrations in prostatic fluid of normal individuals and patients with benign prostatic hypertrophy. Clin Sci (Lond). 1986;70(4):359-63.

Gregory RI, Yan K, Amuthan G, Chendrimada TP, Doratotaj B, Cooch N, Shiekhattar R. The Microprocessor complex mediates the genesis of microRNAs. Nature. 2004;432:235-40.

Griffiths K, Akaza H, Eaton $\mathrm{CL}$, et al. Regulation of prostatic growth. In: Cockett ATK, Khoury S, Aso Y, Chatelain C, Griffiths K, Murphy G, editors. The $2^{\text {nd }}$ International Consultation on Benign Prostatic Hyperplasia (BPH). Jersey: Scientific Communication International; 1993. p. 49-83.

Grosse H. Frequency, localization and associated disorders in urinary calculi. Analysis of 1671 autopsies in urolithiasis. Z Urol Nephrol. 1990;83(9):469-74.

Guntur KV, Guilherme A, Xue L, Chawla A, Czech MP. Map4k4 negatively regulates peroxisome proliferator-activated receptor (PPAR) gamma protein translation by suppressing the mammalian target of rapamycin (mTOR) signaling pathway in cultured adipocytes. J Biol Chem. 2010;285(9):6595603.

Habib FK, Chem C. Pathogenesis of benign prostatic hyperplasia. In: Chisholm G. Handbook on benign prostatic hyperplasia. Nova Jersey: Whitehouse Station; 1994. p.19-31. 
Han J, Lee Y, Yeom KH, Kim YK, Jin H, Kim VN. The Drosha-DGCR8 complex in primary microRNA processing. Genes Dev. 2004;18(24):3016-27.

Hao JM, Chen JZ, Sui HM, Si-Ma XQ, Li GQ, Liu C, Li JL, Ding YQ, Li JM. A five-gene signature as a potential predictor of metastasis and survival in colorectal cancer. J Pathol. 2010;220(4):475-89.

Hayashi M, Kim SW, Imanaka-Yoshida K, Yoshida T, Abel ED, Eliceiri B, Yang Y, Ulevitch RJ, Lee JD. Targeted deletion of BMK1/ERK5 in adult mice perturbs vascular integrity and leads to endothelial failure. J Clin Invest. 2004;113:1138-48.

He L, Hannon GJ. MicroRNAs: small RNAs with a big role in gene regulation. Nat Genet. 2004;5:522-31.

Isaacs JT, Brendler CB, Walsh PC. Changes in the metabolism of dihydrotestosterone in the hyperplastic human prostate. J Clin Endocrinol Metab. 1983;56(1):139-46.

Izmirli M, Arikan B, Bayazit Y, Alptekin D. Associations of polymorphisms in HPC2/ELAC2 and SRD5A2 genes with benign prostate hyperplasia in Turkish men. Asian Pac J Cancer Prev. 2011;12(3):731-3.

Jin P, Wang YH, Peng YG, Hu S, Lu Q, Yang LY. Effect of PI3K/AKT inhibitor on benign prostate hyperplasia and its mechanism: an experimental study. Zhonghua Nan Ke Xue. 2010;16(12):1068-75. 
Joseph MA, Harlow SD, Wei JT, Sarma AV, Dunn RL, Taylor JM, et al. Risk factors for lower urinary tract symptoms in a population-based sample of African-American men. Am J Epidemiol. 2003;157:906-14.

Juniewicz PE, Berry SJ, Coffey DS, Strandberg JD, Ewing LL. The requirement of the testis in establishing the sensitivity of the canine prostate to develop benign prostatic hyperplasia. J Urol. 1994;152(3):996-1001.

Kent OA, Chivukula RR, Mullendore M, Wentzel EA, Feldmann G, Lee KH, Liu S, Leach SD, Maitra A, Mendell JT. Repression of the miR-143/145 cluster by oncogenic Ras initiates a tumor-promoting feed-forward pathway. Genes Dev. 2010;24(24):2754-9.

Kim VN. MicroRNA Biogenesis: Coordinated Cropping and Dicing. Nature. 2005;6:376-85.

Kramer G, Mitteregger D, Maj-Hes A, Sevchenco S, Brozek W. Chronic inflammation as promotor and treatment target in benign prostate hyperplasia (BPH) and in prostate cancer. Urologe A. 2007;46(9):1095-6.

Kranenburg O. The KRAS oncogene: Past, present, and future. Biochim Biophys Acta. 2005;1756(2):81-2.

Kristal AR, Arnold KB, Schenk JM, Neuhouser ML, Weiss N, Goodman P, Antvelink CM, Penson DF, Thompson IM. Race/ethnicity, obesity, health related behaviors and the risk of symptomatic benign prostatic hyperplasia: results from the prostate cancer prevention trial. J Urol. 2007;177(4):1395400. 
Kyriakis JM. MAP kinases and the regulation of nuclear receptors. Sci STKE. 2001;2000(48):pe1.

Lee RC, Feinbaum RL, Ambros V. The C. elegans Heterochronic Gene lin-4 Encodes Small RNAs with Antisense Complementarity to lin-14. Cell. 1993;75:843-854.

Lee SK, Teng Y, Wong HK, Ng TK, Huang L, Lei P, Choy KW, Liu Y, Zhang M, Lam DS, Yam GH, Pang CP. MicroRNA-145 regulates human corneal epithelial differentiation. PLoS One. 2011;6(6):e21249.

Lee Y, Ahn C, Han J, Chol H, Kim J, Yim J, Lee J, Provost P, Radmark O, Kim S, Kim VN. The nuclear Rnase III Drosha initiates microRNA processing. Nature. 2003;425:415-418.

Lee YS, Nakahara K, Pham JW, Kim K, He Z, Sontheimer EJ, Carthew RW. Disctinct Roles for Drosophila Dicer-1 and Dicer-2 in the siRNA/miRNA Silencing Pathways. Cell. 2004;117:69-81.

Lepor H. Pathophysiology, epidemiology, and natural history of benign prostatic hyperplasia. Rev Urol. 2004;6(9):S3-S10.

Lewis BP, Burge CB, Bartel DP. Conserved Seed Pairing, Often Flanked by Adenosines, Indicates that Thousands of Human Genes are MicroRNA Targets. Cell. 2005;120(1):15-20.

Liang JJ, Wang H, Rashid A, Tan TH, Hwang RF, Hamilton SR, Abbruzzese JL, Evans DB, Wang H. Expression of MAP4K4 is associated with worse 
prognosis in patients with stage II pancreatic ductal adenocarcinoma. Clin Cancer Res. 2008;14(21):7043-9.

Liao $\mathrm{CH}$, Guh JH, Chueh SC, Yu HJ. Anti-angiogenic effects and mechanism of prazosin. Prostate. 2011;71(9):976-84.

Lima H, Lorenzetti F. Urologia Fundamental. Nardozza Junior A, Zeratti Filho M, Reis RB. São Paulo: Planmark; 2010. p.195-204.

Liu AW, Cai J, Zhao XL, Jiang TH, He TF, Fu HQ, Zhu MH, Zhang SH. ShRNA-targeted MAP4K4 inhibits hepatocellular carcinoma growth. Clin Cancer Res. 2011;17(4):710-20.

Liu W, Schoenkerman A, Lowe Jr WL. Activation of members of the mitogenactivated protein kinase family by glucose in endothelial cells. Am J Physiol Endocrinol Metab. 2000;279(4):E782-90.

Livak KJ, Schmittgen TD. Analysis of relative gene expression data using real-time quantitative PCR and the 2(-Delta Delta $\mathrm{C}(\mathrm{T})$ ) Method. Methods. 2001;25(4):402-8.

Lucia MS, Lambert JR. Growth factors in benign prostatic hyperplasia: basic science implications. Current Urology Reports. 2008;99(4):272-8.

Luo J, Dunn T, Ewing C, Sauvageot J, Chen Y, Trent J, Isaacs W. Gene expression signature of benign prostatic hyperplasia revealed by cDNA microarray analysis. Prostate. 2002;51(3):189-200. 
Marks LS, Treiger B, Dorey FJ, Fu YS, deKernion JB. Morphometry of the prostate: I. Distribution of tissue components in hyperplastic glands. Urology. 1994;44(4):486-92.

Mehta PB, Jenkins BL, McCarthy L, Thilak L, Robson CN, Neal DE, Leung HY. MEK5 overexpression is associated with metastatic prostate cancer, and stimulates proliferation, MMP-9 expression and invasion. Oncogene 2003;22(9):1381-9.

Meister G, Landthaler M, Patkaniowska A, Dorsett Y, Tuschl T. Sequencespecific inhibition of microRNA- and siRNA-induced RNA silencing. RNA. 2004;10:544-550.

McNeal JE. Anatomy of the prostate and morphogenesis of BPH. Prog Clin Biol Res. 1984;145:27-53,.

McNeal JE. Origin and evolution of benign prostatic elargement. Invest Urol. 1978;15:340-45.

McNeal JE. Prostate. In: Sterenberg SS, editors. Histology for Pathologists, 2nd ed Philadelphia, Lippincott-Raven; 1997. pp. 997-1017.

Michael MZ, O' Connor SM, van Holst Pellekaan NG, Young GP, James RJ. Reduced accumulation of specific microRNAs in colorectal neoplasia. Mol Cancer Res. 2003;1(12):882-91.

Mori H, Maki M, Oishi K, Jaye M, Igarashi K, Yoshida O, Hatanaka M. Increased expression of genes for basic fibroblast growth factor and 
transforming growth factor type beta 2 in human benign prostatic hyperplasia. Prostate. 1990;16(1):71-80.

Morrison AS. Prostatic hypertrophy in greater Boston. J Chronic Dis. 1978;31(5):357-62.

Mostofi FK, Price Jr ED. Tumors of the male genital system. Washington: Army Forces Institute of Pathology n.8; 1973. p.182-85.

Mukamel E, Nissenkorn I, Boner G, Servadio C. Occult progressive renal damage in the elderly male due to benign prostatic hypertrophy. J Am Geriatr Soc. 1979;27(9):403-6.

Neuhouser ML, Schenk J, Song YJ, Tangem CM, Goodman PJ, Pollak M, Penson DF, Thompson IM, Kristal AR. Insulin-like growth factor-I, insulin-like growth factor binding protein-3 and risk of benign prostate hyperplasia in the prostate cancer prevent trial. Prostate. 2008;68(13):1477-86.

Nishimoto S, Nishida E. MAPK signalling: ERK5 versus ERK1/2. EMBO J. 2006;7(8):782-6.

Palmieri A, Pezzetti F, Graziano A, Riccardo D, Zollino I, Brunelli G, Martinelli M, Arlotti M, Carinci F. Comparison between osteoblasts derived from human dental pulp stem cells and osteosarcoma cell lines. Cell Biol Int. 2008;32(7):733-8.

Parsons JK, Kashefi C. Physical activity, benign prostatic hyperplasia, and lower urinary tract symptoms. Eur Urol. 2008;53:1228-35. 
Parsons JK. Modifiable risk factors for benign prostatic hyperplasia and lower urinary tract symptoms: new approaches to old problems. J Urol. 2007;178:395-401.

Partin AW, Oesterling JE, Epstein JI, Horton R, Walsh PC. Influence of age and endocrine factors on the volume of benign prostatic hyperplasia. J Urol. 1991;145(2):405-9.

Partin AW, Page WF, Lee BR, Sanda MG, Miller RN, Walsh PC. Concordance rates for benign prostatic disease among twins suggest hereditary influence. Urology. 1994;44(5):646-50.

Pillai RS, Bhattacharyya SN, Artus CG, Zoller T, Cougot N, Basyuk E, Bertrand E, Filipowicz W. Inhibition of translational initiation by Let-7 MicroRNA in human cells. Science. 2005;309(5740):1573-6.

Prakash K, Pirozzi G, Elashoff M, Munger W, Waga I, Dhir R, Kakehi Y, Getzenberg RH. Symptomatic and asymptomatic benign prostatic hyperplasia: molecular differentiation by using microarrays. PNAS. 2002;(11):7598-603.

Reinhart BJ, Slack FJ, Basson M, Pasquinelli AE, Bettinger JC, Rougvie AE, Horvitz HR, Ruvkun G. The 21-nucleotide let-7 RNA regulates developmental timing in Caenorhabditis elegans. Nature. 2000;403:901-6.

Reis ST. Análise da expressão de MMP-2, MMP-9, MT1-MMP (MMP-14), TIMP-1, TIMP-2, RECK, TGF-Beta e interleucina-8 em câncer de próstata. 
190p. Tese Doutorado. Faculdade de Medicina da Universidade de São Paulo. São Paulo, 2011.

Ricarte Filho JCM, Kimura ET. MicroRNAs: nova classe de reguladores gênicos envolvidos na função endócrina e câncer. Arq Bras Endocrinol Metabol. 2006;6:1102-7.

Risbridger G, Wang H, Young P, Kurita T, Wang YZ, Lubahn D, Gustafsson JÁ, Cunha G, Wong YZ. Evidence that epithelial and mesenchimal estrogen receptor a mediates effects of estrogen on prostatic epithelium. Dev Biol. 2001;229:432-442.

Rohrmann S, Smit E, Giovannucci E, Platz EA. Association between markers of the metabolic syndrome and lower urinary tract symptoms in the Third National Health and Nutrition Examination Survey (NHANES III). Int $J$ Obesity. 2005;29:310-6.

Rouleau M, Leger J, Tenniswood M. Ductal heterogeneity of cytokeratins, gene expression, and cell death in the rat ventral prostate. Mol Endocrinol. 1990;4(12):2003-13.

Sampaio FJB. Neoplasia prostática: conceitos anatômicos fundamentais para a compreensão da patologia benigna e maligna. Int Braz J Urol. 1992;18:121-125.

Sempere LF, Christensen M, Silahtaroglu A, Bak M, Heath CV, Schwartz G, Wells W, Kauppinen S, Cole CN. Altered MicroRNA expression confined to 
specific epithelial cell subpopulations in breast cancer. Cancer Res. 2007 ;67(24):11612-20.

Sanda MG, Beaty TH, Stutzman RE, Childs B, Walsh PC. Genetic susceptibility of benign prostatic hyperplasia. J Urol. 1994;152(1):115-9.

Schaeffer HJ, Weber MJ. Mitogen-activated protein kinases: specific messages from ubiquitous messengers. Mol Cell Biol. 1999;19(4):2435-44.

Scott WW. What makes the prostate grow. J Urol. 1953;70(3):477-88.

Sidney S, Quesenberry C Jr, Sadler MC, Lydick EG, Guess HA, Cattolica EV. Risk factors for surgically treated benign prostatic hyperplasia in a prepaid health care plan. Urology. 1991;38(1):13-9.

Silver RI, Wiley EL, Davis DL, Thigpen AE, Russel DW, McConnel JD. Expression and regulation of steroid 5 alpha-reductase 2 in prostate disease. J Urol. 1994;152(2Pt1):433-7.

Son M, Kim J, Han H, Woo S, Cho YS, Kang Y, Han Y. Expression profiles of protein tyrosine kinase genes in human embryonic stem cells. Reprod Res. 2008;136(4):423-32.

Steiner MS. Review of peptide growth factors in benign prostatic hyperplasia and urological malignancy. J Urol. 1995;153(4):1085-91.

Tang $\mathrm{J}$, Yang J. Etiopathogenesis of benign prostatic hyperplasia. Indian $\mathrm{J}$ Urol. 2009;25(3)312-7. 
The miRNA body map. Available from: http://www.mirnabodymap.org/mirna_card.php. Data de acesso: 18/06/2012. Theyer G, Kramer G, Assmann I, Sherwood E, Preinfalk W, Marberger M, Zechner O, Steiner GE. Phenotypic characterization of infiltrating leukocytes in benign prostatic hyperplasia. Lab Invest. 1992;66(1):96-107.

Untergasser G, Madersbacher S, Berger P. Benign prostatic hyperplasia: agerelated tissue-remodeling. Experimental Gerontology. 2005;40:121-8.

Uson AC, Paez AB, Uson-Jaeger J. The natural history and course of untreated benign prostatic hyperplasia. Eur Urol.152(1):115-9, 1991.

van Rooij E, Olson EN. MicroRNAs: Powerful new regulators of heart disease and provocative therapeutic targets. J Clin Invest. 2007;117:2369-76.

Vermeulen A, Deslypere JP, De Meirleir K. A new look to the andropause: altered function of the gonadotrophs. J Steroid Biochem. 1989;32(1B):163-5.

Walsh PC, Hutchins GM, Ewing LL. Tissue content of dihydrostestosterone in the hyperplasis is not supranormal. J Clin Invest. 1983;72(5):1772-7.

Wang X, Zhang F, Chen F, Liu D, Zheng Y, Zhang Y, Dong C, Su B. MEKK3 regulates IFN-gamma production in $\mathrm{T}$ cells through the Rac1/2-dependent MAPK cascades. J Immunol. 2011;186(10):5791-800.

Wei JT, Calhoun E, Jacobsen SJ. Urologic diseases in America project: benign prostatic hyperplasia. J Urol. 2005;173:1256-61. 
Weinstein-Oppenheimer CR, Blalock WL, Steelman LS, Chang F, McCubrey JA. The Raf signal transduction cascade as a target for chemotherapeutic intervention in growth factor-responsive tumors. Pharmacol Ther. 2000;88(3):229-79.

Wilson JD. The pathogenesis of benign prostatic hyperplasia. Am J Med. 1980;68(5):745-56.

Xin M, Small EM, Sutherland LB. MicroRNAs miR-143 and miR-145 modulate cytoskeletal dynamics and responsiveness of smooth muscle cells to injury. Genes Dev. 2009;23(18):2166-78.

Yang J, Boerm M, McCarty M, Bucana C, Fidler IJ, Zhuang Y, Su B. Mekk3 is essential for early embryonic cardiovascular development. Nat Genet. 2000;24(3):309-13.

Yi R, Qin Y, Macara IG, Cullen BR. Exportin-5 mediates the nuclear export of pre-microRNAs and short hairpin RNAs. Genes Dev. 2003;17:3011-16.

Yoon S, De Micheli G. Prediction of regulatory modules comprising microRNAs and target genes. Bioinformatics. 2005;21(2):ii93-ii100.

Yu L, Su B, Hollomon M, Deng Y, Facchinetti V, Kleinerman ES. Vasculogenesis driven by bone marrow-derived cells is essential for growth of Ewing's sarcomas. Cancer Res. 2010;70(4):1334-43.

Yu ML, Wang JF, Wang GK, You XH, Zhao XX, Jing Q, Qin YW. Vascular smooth muscle cell proliferation is influenced by let-7d microRNA and its interaction with KRAS. Circ J. 2011;75(3):703-9. 
Zhang Z, Duan L, Du X, Ma H, Park I, Lee C, Zhang J, Shi J. The proliferative effect of estradiol on human prostate stromal cells is mediated through activation of ERK. Prostate 2008;68(5):508-16.

Zhou G, Bao ZQ, Dixon JE. Components of a new human protein kinase signal transduction pathway. The J Biol Chem. 1995;270:12665-9. 
APÊNDICES 


\section{Artigos científicos submetidos}

1. Journal of Urology

Role of microRNA 143 and 145 and their target genes in the etiology of benign prostatic hyperplasia

\section{Congressos}

1. XXVIII Congresso Brasileiro de Patologia e XXVIII Congreso de la Sociedad Latinoamericana de Patologia

Perfil do miR-145 e seu gene alvo MAP4K4 na hiperplasia benigna da próstata

2. XXXIII Congresso Brasileiro de Urologia

O papel dos microRNA 143 e 145 na fisiopatologia da hiperplasia benigna da próstata

3. AUA Annual Meeting 2011

Profile of miRNA 143 and 145 and their target genes in benign prostatic hyperplasia

4. AUA Annual Meeting 2012

Profile of microRNA 143 and 145 and their target genes in the pathophysiology of benign prostatic hyperplasia

Ética

1. Aprovação no comitê de ética 0258/10. 
Role of microRNA 143 and 145 and their target genes in the etiology of benign prostatic hyperplasia

Nayara Izabel Viana ${ }^{2}$, Sabrina Thalita dos Reis ${ }^{2}$, Nelson Dip ${ }^{2}$, Miguel Srougi ${ }^{1,2}$, Katia Ramos Moreira Leite ${ }^{2}$, Alberto Azoubel Antunes ${ }^{1,2}$.

Division of Urology ${ }^{1}$ and Laboratory of Medical Investigation ${ }^{2}$ (LIM55), Urology Department, University of Sao Paulo Medical School, Sao Paulo, Brazil

\section{Corresponding author:}

Nayara Izabel Viana

Av. Dr. Arnaldo 455, $2^{\circ}$ floor, room 2145

01246-903, Sao Paulo, Brazil

nayara_viana_2@hotmail.com

Key words: miRNA, benign prostatic hyperplasia, etiology 


\begin{abstract}
Purpose: To analyze the expression of miR-143 and its genes and target proteins KRAS and ERK5 and miR-145 and its genes and target proteins MAP3K3 and MAP4K4 in an attempt to investigate the possible involvement of these molecules in the pathogenesis of the disease.
\end{abstract}

Materials and Methods: The study comprised the analysis of specimens from 44 patients diagnosed with $\mathrm{BPH}$. The control group was consisted of prostate fragments from two young patients who were organ donors. MiRNAs and their target genes were assessed using the qRT-PCR and protein by Western blotting.

Results: miR-143 and miR-145 showed overexpression in $62.5 \%$ and $73.8 \%$ of cases, respectively. The gene ERK5 presented a underexpression in $59.4 \%$, suggesting a possible negative control by the miR-143. The MAP4K4 gene showed underexpression in all the samples studied, demonstrating a possible control by the miR-145. The KRAS and MAP3K3 genes showed overexpression in $79.4 \%$ and $61.5 \%$ of the samples respectively. According protein expression, increased expression was found in the KRAS (4312.2 luminance / area) and MAP3K3 (7461.7 luminance / area). ERK5 protein was more present in samples of patients with prostate larger than 60 grams $(p=0.019)$.

Conclusions: miR-143 is overexpressed in patients with $\mathrm{BPH}$ and appears to control expression of ERK5. KRAS is overexpressed in patients with $\mathrm{BPH}$. miR-145 is overexpressed in patients with $\mathrm{BPH}$ and appears to control expression of MAP4K4. MAP3K3 is overexpressed in patients with BPH. Considering the clinical parameters, ERK5 protein showed higher expression in larger prostates. 


\section{Introduction}

Benign Prostatic Hyperplasia (BPH) is one of the most common urologic diseases among elderly men (1). The disease is characterized by a marked stromal and acinar proliferation, which results in the occurrence of LUTS (lower urinary tract symptoms) (2), that may affect the quality of life of the patients (3). BPH pathogenesis has not been fully elucidated but it is known that some factors increase the risk of occurrence of the problem. Due to the absence of a more precise definition for the condition, the molecular changes related to disease have been an ongoing interest of many studies (4).

MicroRNAs (miRNA) are a group of small RNA molecules that have between 19 and 25 nucleotides with fundamental action in regulating the expression of genes in plants and animals (5). These small molecules were discovered almost 20 years ago (6) and since then have been recognized as molecules that act specifically on post-transcriptional control in most of the eukaryotic genomes. They are involved in a number of cellular processes such as apoptosis, differentiation, cell proliferation and development (7), hematopoiesis (8), metabolic and pathways signaling and maintenance of pluripotent cells, which can act as enhancers or suppressors of a cell activity specific. Additionally, aberrant expression of these small RNAs has been linked to human disease (9).

miR-143 and miR-145 play a fundamental role in differentiation and proliferation of smooth muscle cells, still having the ability to control the quiescent versus proliferative phenotype (10). These miRNAs seem to have a key role in the development and differentiation of cardiac muscle and skeletal remodeling in response to tissue injury (11). miR-143 has as target genes KRAS and ERK5 and miR-145 has as target genes MAP3K3 and MAP4K4. These genes are important members of the MAP kinase signaling cascades, involved in regulation of many cellular processes including differentiation, proliferation and survival (12). 
The actions of miR-143 and 145 and their target genes in prostate smooth muscle tissue have never been described. The study, these miRNAs in the prostatic tissue could help in understanding the etiology of BPH, as well as serve as the basis for the development of novel therapeutic targets for disease treatment.

Therefore, the objectives of this study were to analyze the expression of miR-143 and its genes and target proteins KRAS and ERK5 and miR-145 and its genes and target proteins MAP3K3 and MAP4K4 in patients with $\mathrm{BPH}$. We also compared these gene expression profiles and protein with some clinical parameters of patients: PSA, bladder catheter, prostate weight and age.

\section{Materials and Methods}

\subsection{Patients}

The study comprised the analysis of specimens from 44 patients diagnosed with BPH surgically treated by transurethral resection of the prostate or open prostatectomy in Hospital das Clínicas of University of São Paulo Medical School. Exclusion criteria were: previous prostatic surgery, pelvic radiotherapy, prostate cancer and use of 5 alpha-reductase inhibitors. The control group was represented by prostate fragments (transition zone) from two young patients who were organ donors.

Surgical specimens were collected immediately after surgery. A fragment of $1 \mathrm{~cm}^{2}$ was sectioned from the transition zone of the prostate was stored at $-80^{\circ} \mathrm{C}$. The samples were used for analysis of expression of miRNAs, target genes and proteins.

Patients were divided into groups according to clinical parameters (Table 1). We analyzed the serum levels of preoperative PSA $(\leq 4 \mathrm{ng} / \mathrm{ml}$ and $>4 \mathrm{ng} / \mathrm{ml}$ ), use or nonuse of urinary catheter, prostate volume on ultrasound ( $\leq 60 \mathrm{~g}$ and $>60 \mathrm{~g}$ ), and patients age ( $\leq 65$ years and $>65$ years). 


\subsection{Isolation of RNA and miRNA}

For RNA and miRNA extraction we used mirVana kit (Ambion, Austin, TX) and CDNA was obtained using the TaqMan miRNA Reverse Transcription kit (Applied Biosystems, Foster City, CA) for miRNA and the High-Capacity cDNA Reverse Transcription kit for RNA, according manufacturer's recommendations.. A quantity of 10ng miRNA was subjected to reverse transcription using primer stem-loop with the sequence-specific miRNA-143 and 145. The reaction for obtaining cDNA from miRNA PCR was performed in equipment Veriti (Applied Biosystem, Foster City, CA) according to the following parameters: $30 \mathrm{~min}$ at $16^{\circ} \mathrm{C}, 30$ minutes at $42{ }^{\circ} \mathrm{C}$ and 5 minutes at $85^{\circ} \mathrm{C}$. To obtain cDNA from RNA was used the same equipment, using the following parameters: $10 \mathrm{~min}$ at $25^{\circ} \mathrm{C}, 120$ minutes at $37^{\circ} \mathrm{C}$ and 5 minutes at $85^{\circ} \mathrm{C}$.

\subsection{Analysis of gene expression}

The expression of miRNA and RNA studied was assessed using Polymerase chain reaction methodology in real time quantitative (qRT-PCR) system ABI7500 Fast mode standard RT-PCR using Taqman Universal PCR Master Mix (Applied Biosystems, Foster City, CA ). The expression of miRNA and RNA individual was analyzed using sequence-specific primers.

miRNA expression levels and the target genes was obtained by relative quantification and threshold expression levels determined by $2^{-\triangle \triangle C T}$ method. All reactions were performed in duplicate and RNU43 was used as 
endogenous control of miRNAs, whereas $\beta 2$-microglobulin (B2M) played this role for RNAs.

\subsection{Western Blot}

We used specimens from 38 of 44 patients. The control group was represented by the same samples used for gene expression. The samples were macerated in TissueLyser (Qiagen $\circledast$ ) equipment with RIPA lysis buffer (Lysis Buffer, Millipore) containing protease and phosphatase inhibitors. The samples were centrifuged in a refrigerated centrifuge for 20 minutes at $15,000 \mathrm{rpm}$ at $4{ }^{\circ} \mathrm{C}$. The supernatant was collected and mixed with sample buffer in a 1:1 ratio. Protein samples at concentration of $100 \mathrm{ng} / \mathrm{ml}$ were loaded on the $12 \%$ acrilamide gels (Bio-Rad; Mini-Protean TGX) and subjected to electrophoretic run. For sample transfer, we used the membrane polyvinylidene fluoride (PVDF) which was submitted along with the gel, and electric field $300 \mathrm{~mA}$ for 2 hours. Incubation of antibodies was performed using the apparatus SNAP (SNAP id system - Millipore). Each membrane was blocked with 1\% BSA (Albumin, bovine serum from - Sigma) diluted in TBS-T (Tris buffer saline Tween 20) for 15 seconds. Primary antibodies were diluted in BSA dilution suggested by the manufacturer, ERK5 (1:1000, Upstate), KRAS (1:500; Abnova), MAP3K3 (1:1000, Upstate) and MAP4K4 (1:500; Abnova). The membranes were incubated for 10 minutes at room temperature, followed by incubation with secondary antibody. We used $\beta$ actin antibody (1:500, Millipore) as normalizer. Finally, the blots were subjected to the detection device Alliance 4.7 (Uvitec Cambridge). Quantitative analysis was performed in software Alliance 16.06. 
Statistical analysis was performed using the SPSS 19.0 software. For comparison of gene expression, miRNAs and proteins with clinical variables, we used the Student's t test for homogeneous variables and Mann-Whitney $\mathrm{U}$ test for non-homogeneous variables. For all statistical analysis we considered the level of significance of $5 \%(P<0.05)$.

\section{Results}

Analysis of miR-143 and ERK5 and KRAS genes showed that miR143 is overexpressed in most cases (62.5\%) as well KRAS gene $(79.4 \%)$ and that the ERK5 gene presented underexpression (59.4\%) in most hyperplastic tissues compared with normal prostate tissue (Figure 1, Table 2). In the same comparison, miR-145 appeared overexpressed (73.8\%) as well MAP3K3 gene (61.5\%) and MAP4K4 gene presented underexpression in $100 \%$ of samples (Figure 2, Table 2).

Considering miR-143 and miR-145 expressions and ERK5, KRAS, MAP3K3 and MAP4K4 genes, compared with clinical parameters, preoperative PSA, bladder catheter, prostate weight and age, we found no statistical correlations (Table 3).

Analysis of proteins encoded by the genes ERK5, KRAS, MAP3K3 and MAP4K4 is shown in Figure 3. We found strong expression of MAP3K3 and KRAS proteins. Means of expression are normalized from B-actin levels (Tabel 4).

Expression analysis of ERK5, KRAS, MAP3K3 and MAP4K4 proteins compared with the clinical parameters, that is, preoperative PSA, bladder catheter, prostate weight in ultrasound and age is shown in Table 5. The only statistically significant difference was found regarding ERK5 protein that is expressed in most patients with prostate greater than 60 grams $(p=0.019)$. 


\section{Discussion}

So far, the action of miRNAs in BPH was poorly explored. In the present study, we found an overexpression of miRNA 143 and 145 in 62.5\% and $73.8 \%$ of cases, respectively. These miRNAs target a number of transcription factors involved in differentiation and proliferation of smooth muscle cells (12). The major reason for our investigation about these miRNAs and their possible roles in BPH is a significant increase of smooth muscle fibers related to disease (13). BPH attends high cell proliferation, which make us assume that overexpression of both miRNAs studied may be responsible to cellular abundance found in $\mathrm{BPH}$.

In the cardiac muscle, miR-143 and miR-145 can regulate quiescent versus proliferative phenotype in smooth muscle cell. Moreover, miR-145 is instrumental in defining the fate of smooth muscle, being associated with contractile phenotype (14) Our hypothesis is that these miRNAs may be acting not only in increased stromal proliferation in prostate tissue, but also contributing to induction of contractile phenotype which has been shown in $\mathrm{BPH}$.

There are several reports in literature that show involvement of miR143 and miR-145 in modulating cellular activities important for example in cardiac morphogenesis (12), in maintaining aortic smooth muscle cells (15) and modulation response of cytoskeletal smooth muscle cells to an injury (16). The strong expression of miR-143 and miR-145 in human corneal epithelium has been linked to the regulation and formation of epithelium, as well as maintaining its integrity (17).

Growth factors are mentioned as potent stimulators of cell proliferation in normal prostates and gland hyperplasia. This important group of peptides and their cellular receptors are found in high amounts in $\mathrm{BPH}$ when compared to normal prostates. The growth factor TGF- $\beta$ uses distinct pathways for transcriptional activation of miR-143 and miR-145 in smooth 
muscle cells in human coronary artery (18), thus constituting a hypothesis to explain the overexpression of these miRNAs found in our work.

ERK5 is a member of MAPK superfamily involved in regulation of several cellular processes, including differentiation, proliferation and survival (12). We found a underexpression of ERK5 in $59.4 \%$ of cases. With respect to protein analysis, ERK5 showed decreased expression in samples of BPH compared with normal tissue. This fact is probably due to miR-143 overexpression, since miRNAs can negatively regulate gene expression through post-transcriptional mechanisms. Overexpression of miR-143 and decreased expression of ERK5 has been correlated with decreased cell proliferation in prostate cancer cell lines (19). In our study, miR-143 may be even suppressing the action of ERK5 in BPH but in vitro studies should be conducted to confirm this regulation. However, these results are contradictory to the reports in the literature that show an overactivity of ERK5 in BPH (20).

Despite the decreased mRNA and protein ERK5 in most cases hyperplasia, there was an increased protein expression in prostate greater than 60 grams $(p=0.019)$. The presence of ERK5 protein has been associated with stimulation of proliferation in prostate cancer, and our work may be experiencing the same, because the presence of this protein allows activation of factors related to cell growth (21). Our results may demonstrate that this signaling pathway is important in the pathophysiology of $\mathrm{BPH}$, but occurs later and is responsible for larger prostates.

KRAS gene triggers many signal transduction pathways. We found an overexpression of both KRAS gene and protein in $79.5 \%$ of cases, with means of 2.41 and 4312,2 , respectively. We were able to observe great differences in protein levels when we compared $\mathrm{BPH}$ and normal prostatic tissues $(p=0,06)$. These results can be attributed to the lack of control by miR-143 over KRAS gene. Thus, the protein product of the normal KRAS gene may be performing essential functions in normal tissue signaling (22). 
KRAS can be activated in response to various extracellular signals, mainly by growth factors and cytokines. As mentioned earlier, the growth factors are found in greater amounts in hyperplastic glands and may trigger KRAS activation observed in our findings. Furthermore, there is a possibility that BPH could result from an action immune cell site (23) and in this condition cytokines are produced in different stages. Given these observations, cytokines can also be responsible for KRAS activation in BPH.

Activating KRAS is responsible for activating receptors signal as Raf and PI3K. The biological consequences of PI3K activation include proliferation, cell survival, motility, and intracellular trafficking. Overexpression of KRAS found could trigger the PI3K pathway that have been associated with increased proliferation and decreased apoptosis BPH animal models (24).

Regarding MAP3K3 gene, an overexpression was found in $61.5 \%$ of cases, while MAP3K3 protein occurred in $100 \%$ of them (means of 1.21 and 7461.7, respectively). These results show that, in $\mathrm{BPH}$, this gene is probably not regulated by miR-145. MAP3K3 is a member of the MAP kinase signaling cascade and is responsible for directly activating ERK pathway components, but this finding was not observed in our study, that have demonstrated ERK5 underexpression. However, overexpression of KRAS may be related to MAP3K3 overexpression because gene is responsible for activation of members of MAPK signaling pathway.

MAP3K3 plays a crucial role in angiogenesis and vasculogenesis. Yang et al. (2000) showed that, in mice, MAP3K3 inactivation led strong disturbance in boold vessels development and early death of embryos (25). Overexpression of MAP3K3 and its protein product observed in our study may be responsible for increased angiogenesis due to proliferative process associated with disease. Adrenoceptor antagonists as prazozin are routinely used for the treatment of $\mathrm{BPH}$ and its activities is the inhibition of angiogenesis showing that this is an important phenomenon of the disease, perhaps promoted by the activity of MAP3K3. Moreover, MAP3K3 
overexpression have been also observed in human embryonic stem cells and associated to cell maintenance and differentiation (26).

MAPKs play important roles in regulating immune response and immune cells development as well as activation, differentiation and survival. MAP3K3 protein is constitutively expressed in $\mathrm{T}$ lymphocytes (27). T effectors lymphocytes are found near the prostatic ducts in a number about six times higher in men over 55 years old. This may indicate that over the years, an autoimmune phenomena generated by some specific antigen appears in the prostate (23). As a result, microenvironment surrounding the prostate epithelial cells would be swamped by lymphokines which can influence local production of growth factors and angiogenesis in prostate tissue (28). Thus, MAP3K3 overexpression in T lymphocytes could be contribute to this process as well as to induce angiogenesis. In accordance with these findings, we found the presence of MAP3K3 protein in all BPH samples.

Underexpression of MAP4K4 was found in all samples (mean of 0.16 ). MAP4K4 protein was absent in $65.8 \%$ of cases, with different means for BPH and normal tissues (2827.3 vs 4103.6, respectively $p=0,041$ ). This relationship demonstrates that this gene may be under regulation by miR-145 and consequent mTOR pathway stimulation, which plays a central role in many cellular processes involved in cell growth, including smooth musculature (29). Our main hypothesis is that MAP4K4 underexpression, in this case controlled by miR-145, can fail to downregulate mTOR which can lead to an irregular cell proliferation responsible for $\mathrm{BPH}$.

We believe that miR-143 and miR-145 may be involved in BPH pathogenesis by altering the homeostasis of fibromuscular tissue mainly by controlling proliferation and differentiation and interfering with expression of MAP4K4 and ERK5. The MAP3K3 and KRAS genes do not appear to be being regulated by miR-143 and 145 in BPH and may be involved in important events responsible for developing the disease, initiating important 
signaling pathways, resulting in increased proliferation, cell survival, angiogenesis and intracellular trafficking.

The pathogenesis of BPH is not yet fully understood and this new study allows us to affirm that the change in miRNA expression may be involved in disease development. Additional studies with other miRNAs are likely to provide important information for understanding the disease and suggest possible new therapies.

\section{Conclusions}

miR-143 is overexpressed in patients with $\mathrm{BPH}$ and appears to control expression of ERK5. KRAS is overexpressed in patients with BPH. miR-145 is overexpressed in patients with $\mathrm{BPH}$ and appears to control expression of MAP4K4. MAP3K3 is overexpressed in patients with BPH. Considering the clinical parameters, ERK5 protein showed higher expression in larger prostates.

Grant sponsors: This study was supported by FAPESP (Fundação de Amparo à Pesquisa do Estado de Sao Paulo) under protocol number 2010/50786-2.

\section{References}

1. Bianchi-Frias D, Vakar-Lopez F, Coleman IM. The effects of aging on the molecular and cellular composition of the prostate microenvironment. PSPLoS One. 5(9): 12501, 2010

2. Schauer IG, Rowley DR. The functional role of reactive stroma in benign prostatic hyperplasia. Differentiation. 82(4-5):200, 2011

3. Franco-Salinas G, de la Rosette JJMHC, Michel MC. Pharmacokinetics and Pharmacodynamics of Tamsulosin in its 
Modified-Release and Oral Controlled Absorption System Formulations. Clin Pharmacokinet. 49(3):177, 2010

4. Tang J, Yang J. Etiopathogenesis of benign prostatic hyperplasia. Indian J Urol. 25(3): 312, 2009

5. Pillai RS, Bhattacharyya SN, Artus CG. Inhibition of translational initiation by Let-7 MicroRNA in human cells. Science. 309(5740):1573, 2005

6. Lee RC, Feinbaum RL, Ambros V. The C. elegans Heterochronic Gene lin-4 Encodes Small RNAs with Antisense Complementarity to lin-14. Cell. 75:843, 1993

7. Reinhart BJ, Slack FJ, Basson M. The 21-nucleotide let-7 RNA regulates developmental timing in Caenorhabditis elegans. Nature. 403:901, 2000

8. Ambros V. The functions of animal microRNAs. Nature. 431:350, 2004

9. Ricarte Filho JCM, Kimura ET. MicroRNAs: nova classe de reguladores gênicos envolvidos na função endócrina e câncer. Arquivos Brasileiros de Endocrinologia e Metabologia. 6:1102, 2006

10. Chen JF, Callis TE, Wang DZ. microRNAs and muscle disorders. Journal of Cell Science. 122: 13, 2009

11. Cordes KR, Sheehy NT, White MP. miR-145 and miR-143 regulate smooth muscle cell fate and plasticity. Nature. 460:705, 2009

12. Nishimoto S, Nishida E. MAPK signalling: ERK5 versus ERK1/2. EMBO J. 7(8):782, 2006

13. Chagas MA, Babinski MA, Costa WS. Stereological analysis of histologic components in transition zone of normal and hyperplastic human prostates. Braz J Urol. 27:26, 2001

14. Boettger T, Beetz N, Kostin S. Acquisition of the contractile phenotype by murine arterial smooth muscle cells depends on the Mir143/145 gene cluster. The Journal of Clinical Investigation. 119:2634, 2009

15. Elia L, Quintavalle M, Zhang J. The knockout of miR-143 and -145 alters smooth muscle cell maintenance and vascular homeostasis in 
mice: correlates with human disease. Cell Death Differ. 16(12):1590, 2009

16. Xin M, Small EM, Sutherland LB. MicroRNAs miR-143 and miR-145 modulate cytoskeletal dynamics and responsiveness of smooth muscle cells to injury. Genes Dev. 23(18):2166, 2009

17. Lee SK, Teng Y, Wong HK. MicroRNA-145 regulates human corneal epithelial differentiation. PLoS One. 6(6):e21249, 2011

18. Long X, Miano JM. Transforming Growth Factor-\{beta\}1 (TGF-\{beta\}1) Utilizes Distinct Pathways for the Transcriptional Activation of MicroRNA 143/145 in Human Coronary Artery Smooth Muscle Cells. J Biol Chem. 286(34):30119, 2011

19. Clapé C, Fritz V, Henriquet C. miR-143 interferes with ERK5 signaling, and abrogates prostate cancer progression in mice. PLoS One. 4(10):e7542, 2009

20.Zhang Z, Duan L, Du X. The proliferative effect of estradiol on human prostate stromal cells is mediated through activation of ERK. Prostate. 68(5):508, 2008

21. Mehta PB, Jenkins BL, McCarthy L. MEK5 overexpression is associated with metastatic prostate cancer, and stimulates proliferation, MMP-9 expression and invasion. Oncogene. 22(9):1381, 2003

22. Kranenburg O. The KRAS oncogene: Past, present, and future. Biochimica et Biophysica Acta. 1756(2):81, 2005

23. Theyer G, Kramer G, Assmann I. Phenotypic characterization of infiltrating leukocytes in benign prostatic hyperplasia. Lab Invest. 66(1):96, 1992

24. Jin $P$, Wang $Y H$, Peng $Y G$. Effect of PI3K/AKT inhibitor on benign prostate hyperplasia and its mechanism: an experimental study. Zhonghua Nan Ke Xue. 16(12):1068, 2010

25. Yang J, Boerm M, McCarty M. Mekk3 is essential for early embryonic cardiovascular development. Nat Genet. 2000;24(3):309, 2000 
26. Son M, Kim J, Han H. Expression profiles of protein tyrosine kinase genes in human embryonic stem cells. Reproduction Research. 136(4):423, 2008

27. Wang $X$, Zhang $F$, Chen F. MEKK3 regulates IFN-gamma production in T cells through the Rac1/2-dependent MAPK cascades. J Immunol. 186(10):5791, 2011

28. Lucia MS, Lambert JR. Growth factors in benign prostatic hyperplasia: basic science implications. Current Urology Reports. 99(4):272, 2008

29. Guntur KV, Guilherme A, Xue L. Map4k4 negatively regulates peroxisome proliferator-activated receptor (PPAR) gamma protein translation by suppressing the mammalian target of rapamycin (mTOR) signaling pathway in cultured adipocytes. J Biol Chem. 285(9):6595, 2010 


\section{Tables}

Table 1. Demographic characteristics of 44 patients who underwent surgical treatment for $\mathrm{BPH}$

\begin{tabular}{|c|c|}
\hline PSA (ng/ml) & \\
Average & 4,7 \\
Minimum - Maximum & $01-30,2$ \\
$\leq 4 \mathrm{n}(\%)$ & $28(63.6 \%)$ \\
$>4 \mathrm{n}(\%)$ & $16(36.4 \%)$ \\
\hline Use of bladder catheter & \\
Yes $\mathrm{n}(\%)$ & $21(47 \%)$ \\
No $\mathrm{n}(\%)$ & $23(53 \%)$ \\
\hline Prostate volume (grams) & \\
Average & 67 \\
Minimum - Maximum & $24-200$ \\
$\leq 60 \mathrm{n}(\%)$ & $15(34 \%)$ \\
$>60 \mathrm{n}(\%)$ & $29(66 \%)$ \\
\hline Age (years) & \\
Average & 66 \\
Minimum - Maximum & $46-88$ \\
$\leq 65 \mathrm{n}(\%)$ & $21(47 \%)$ \\
$>65 \mathrm{n}(\%)$ & $23(53 \%)$ \\
\hline
\end{tabular}

Table 2. miRNA and genes expression levels in 44 patients with BPH

\begin{tabular}{|l|c|c|c|c|c|c|}
\hline & miR-143 & ERK5 & KRAS & miR-145 & MAP3K3 & MAP4K4 \\
\hline Average & 3.60 & 0.88 & 2.41 & 3.97 & 1.21 & 0.16 \\
\hline $\begin{array}{l}\text { Standard } \\
\text { Deviation }\end{array}$ & 7.80 & 0.61 & 2.09 & 5.41 & 0.78 & 0.12 \\
\hline Overexpression & $62.5 \%$ & $40.5 \%$ & $79.4 \%$ & $73.8 \%$ & $61.5 \%$ & $0 \%$ \\
\hline Underexpression & $37.5 \%$ & $59.4 \%$ & $20.5 \%$ & $26.2 \%$ & $38.4 \%$ & $100 \%$ \\
\hline
\end{tabular}


Table 3 - Gene expression according preoperative PSA, bladder catheter, prostate weight and age

\begin{tabular}{|c|c|c|c|c|c|c|c|c|c|c|c|c|}
\hline & $\begin{array}{c}\leq 4 \mathrm{ng} / \mathrm{ml} \\
(\mathrm{n}=28)\end{array}$ & $\begin{array}{c}>4 \mathrm{ng} / \mathrm{ml} \\
(\mathrm{n}=16)\end{array}$ & $p$ & $\begin{array}{c}\text { No } \\
(n=23)\end{array}$ & $\begin{array}{c}\text { Yes } \\
(n=21)\end{array}$ & $p$ & $\begin{array}{l}\leq 60 \mathrm{~g} \\
(\mathrm{n}=15)\end{array}$ & $\begin{array}{l}>60 \mathrm{~g} \\
(\mathrm{n}=29)\end{array}$ & $p$ & $\begin{array}{c}\leq 65 \text { years } \\
\quad(n=23)\end{array}$ & $\begin{array}{c}>65 \text { years } \\
(n=21)\end{array}$ & $p$ \\
\hline $\mathrm{miR}-143$ & 2.29 & 4.34 & $0.407^{* *}$ & 3.54 & 3.66 & $0.957^{* *}$ & 2.05 & 6.59 & $0.407^{*}$ & 2.25 & 5.08 & $0.916^{* *}$ \\
\hline ERK5 & 1.08 & 0.76 & $0.205^{*}$ & 0.84 & 0.91 & $0.707^{*}$ & 0.85 & 0.93 & $0.633^{*}$ & 0.96 & 0.79 & $0.360^{*}$ \\
\hline KRAS & 2.62 & 2.29 & $0.613^{* *}$ & 2.82 & 1.96 & $0.179^{\star *}$ & 2.05 & 3.11 & $0.194^{*}$ & 2.41 & 2.41 & $0.989^{*}$ \\
\hline
\end{tabular}

* T Test

${ }^{* *}$ Mann-Whitney U test 
Table 4. Average expression and percentage of presence and absence by Western Blotting of proteins ERK5, KRAS, MAP3K3, MAP4K4 and $\beta$-actin evaluated in 38 patients with $\mathrm{BPH}$ and in normal controls.

\begin{tabular}{|l|c|c|c|c|c|}
\hline Western Blot & ERK5 & KRAS & MAP3K3 & MAP4K4 & $\beta$-actin \\
\hline Mean (BPH) & 3240.8 & 4312.2 & 7461.7 & 2827.3 & 5752.9 \\
\hline $\begin{array}{l}\text { Mean (normal } \\
\text { prostate) }\end{array}$ & 3619.4 & 1397.1 & 2726.2 & 4103.6 & 5601.5 \\
\hline Presence & $78.94 \%$ & $100 \%$ & $100 \%$ & $34.21 \%$ & $100 \%$ \\
\hline Absence & $21.06 \%$ & & & $65.79 \%$ & \\
\hline
\end{tabular}


Table 5. ERK5, KRAS, MAP3K3 and MAP4K4 protein expression in accordance with clinical preoperative PSA, bladder catheter, prostate weight and age.

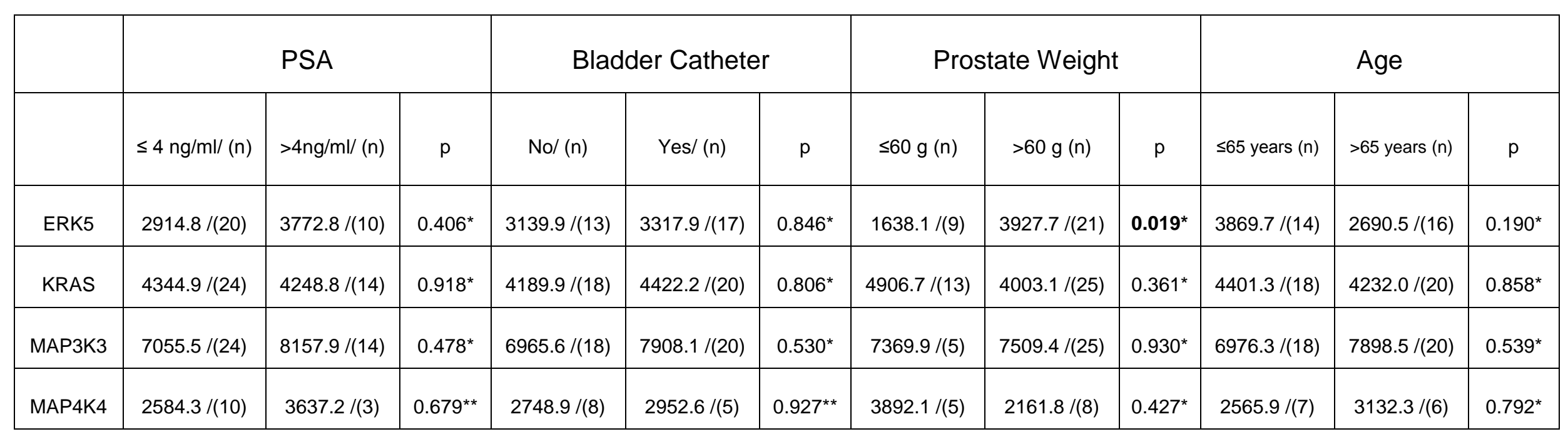

\footnotetext{
* T Test
} 


\section{Legends of Figures}

Figure 1. Expression profile of miR-143 and KRAS and ERK5 genes in 44 patients with $\mathrm{BPH}$.

Figure 2. Expression profile of miR-145 and MAP3K3 and MAP4K4 genes in 44 patients with $\mathrm{BPH}$.

Figure 3. KRAS, MAP3K3, ERK5, MAP4K4 and $\beta$-actin proteins in $\mathrm{BPH}$ and normals tissue samples. HeLa cell line was used as a positive control for KRAS and ERK5, and 3T3/A31 for MAP3K3 and MAP4K4. 
Figure 1

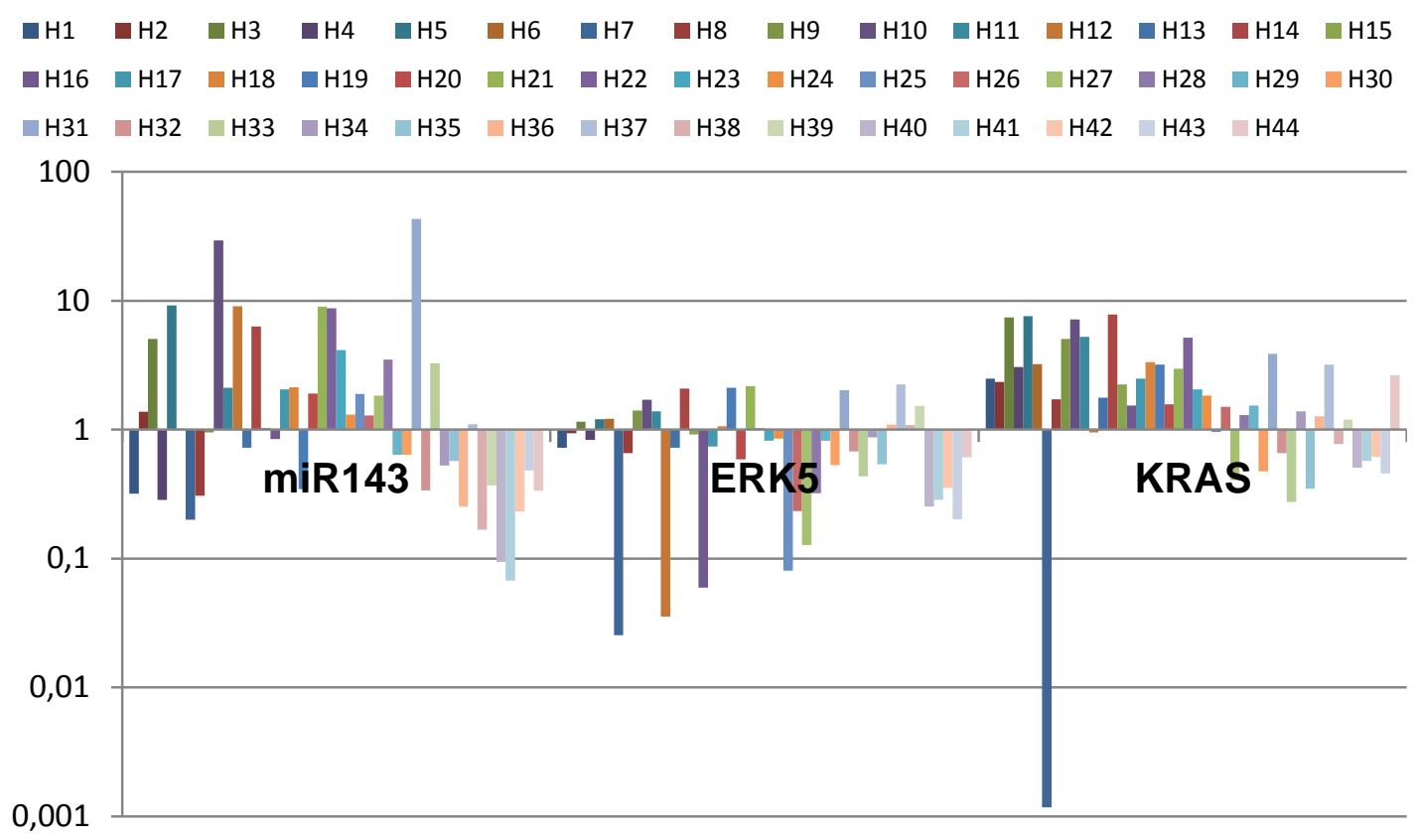

Figure 2

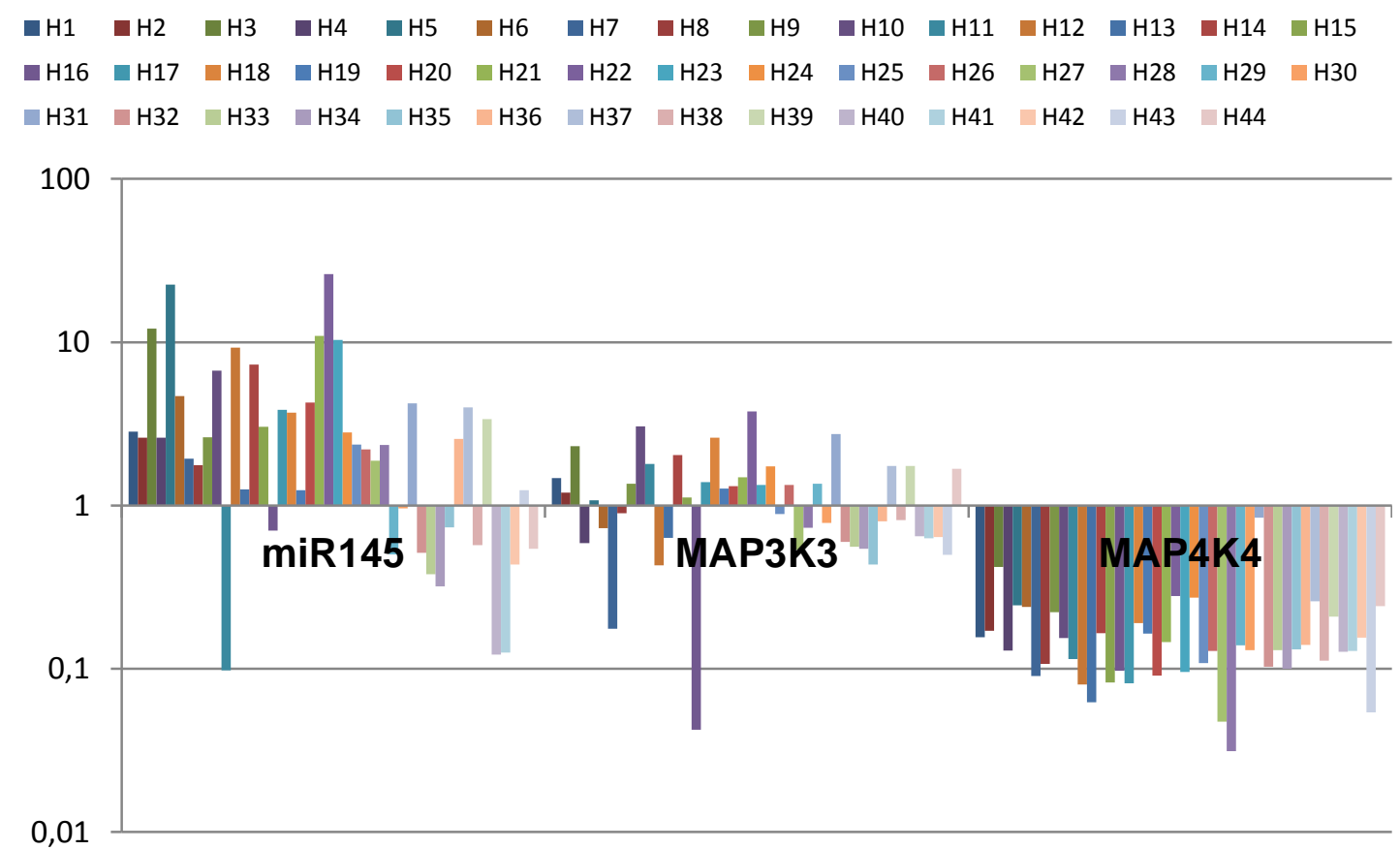


Figure 3

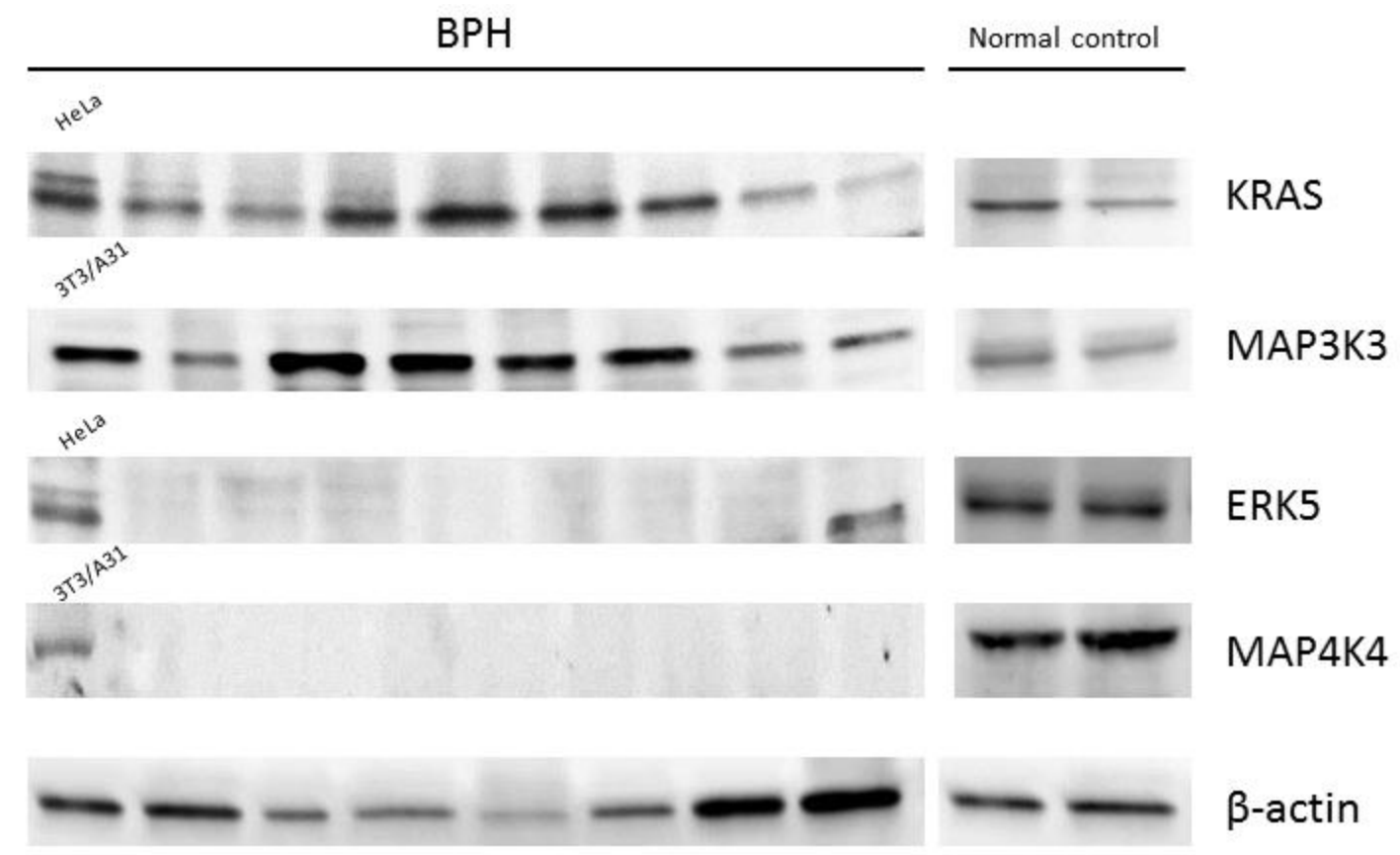




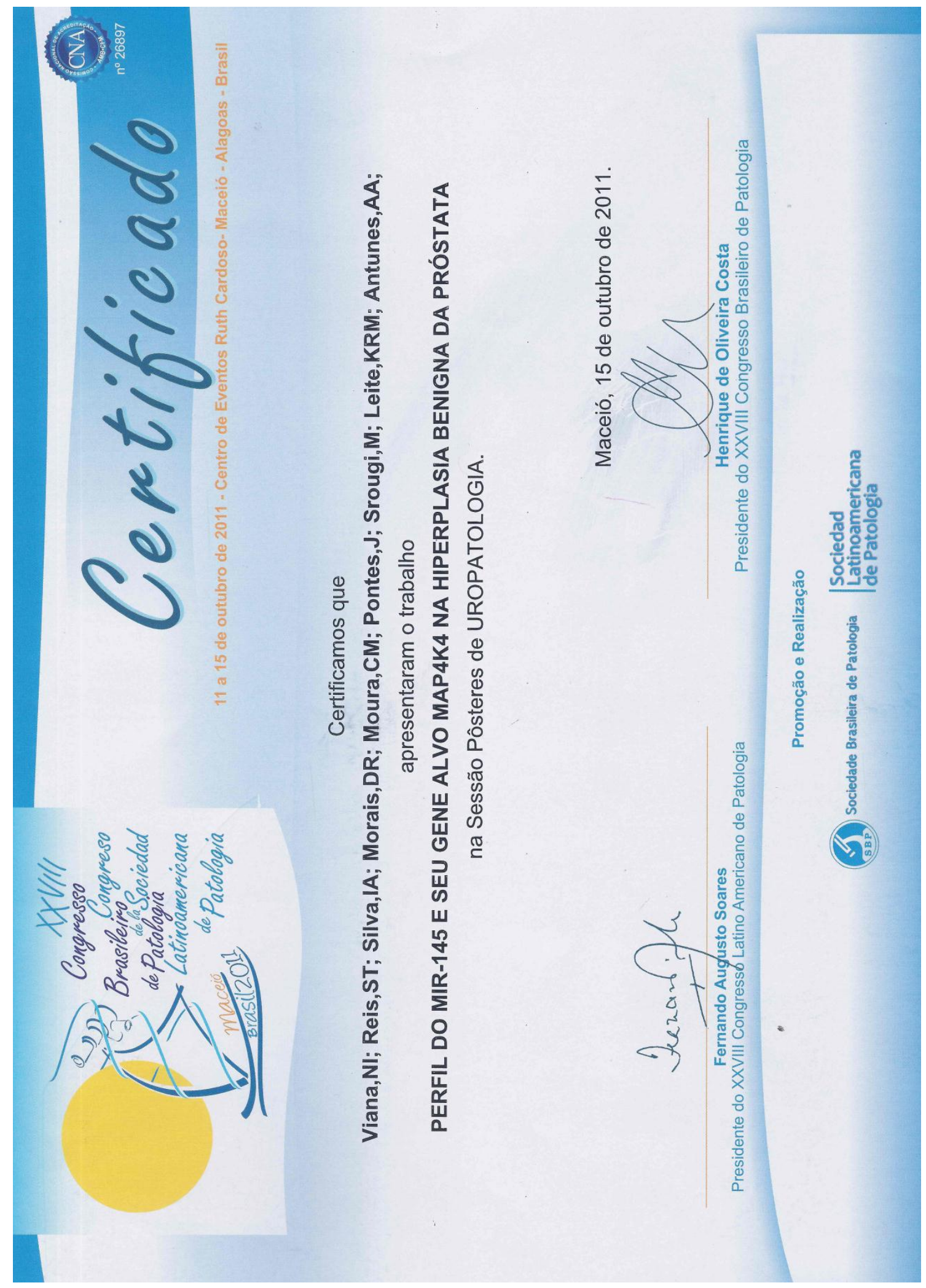




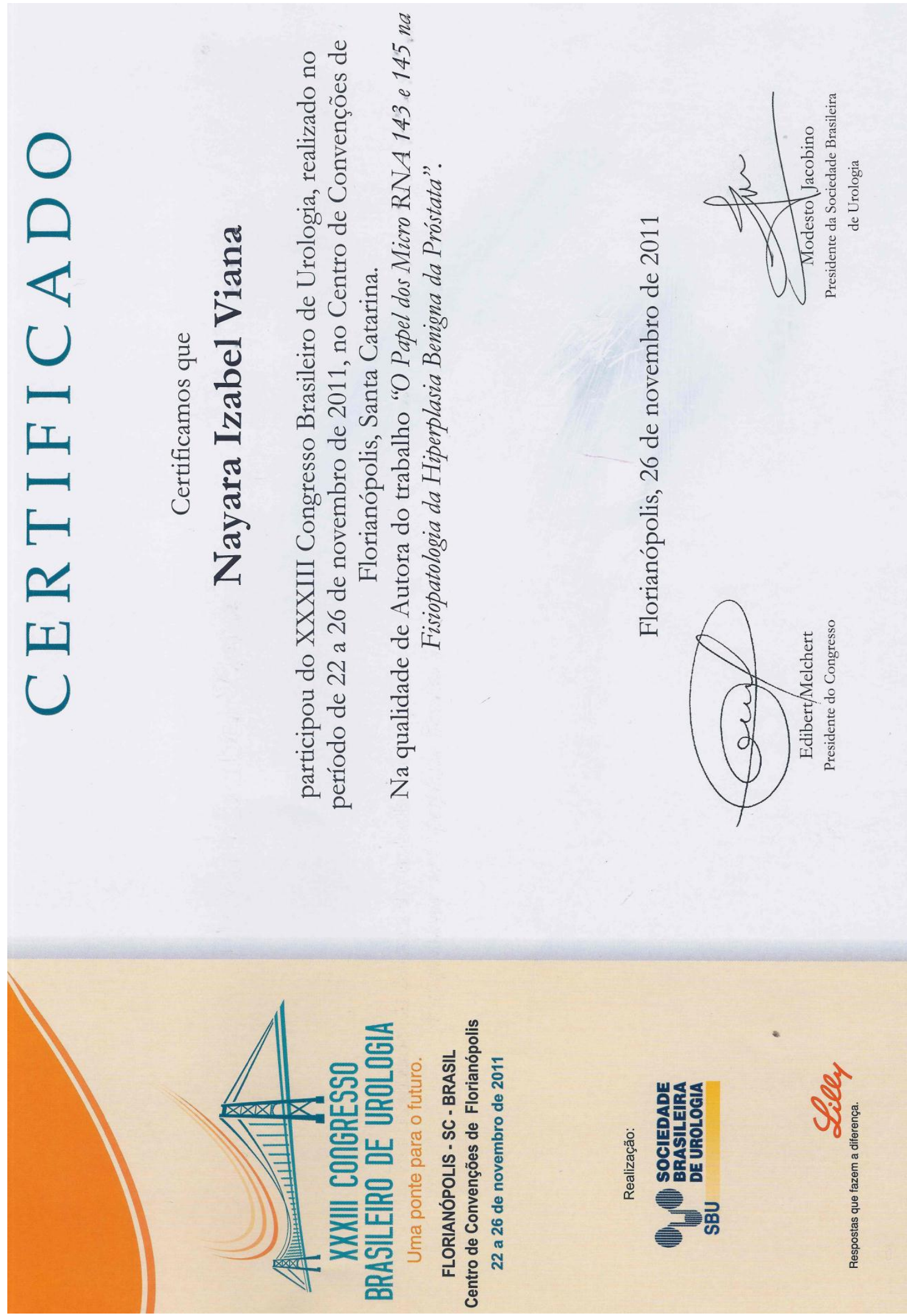


1737

PROFILE OF MICRO RNA 143 AND 145 AND THEIR TARGET GENES IN BENIGN PROSTATIC HYPERPLASIA

Nayara Viana", Sabrina Reis, Iran Silva, Miguel Srougi, Alberto Antunes, Katia Leite, Sâo Paulo, Brazil

INTRODUCTION AND OBJECTIVES: Benign Prostatic Hyperplasia (BPH) is the most common prostate disorder and is the most common benign tumor in men. In the United States 14 million men have symptoms of BPH and worldwide this number reaches 30 million men. Micro RNAs (miRNA) are a large class of small non coding RNA molecules that act as regulators of the expression of genes, including cell proliferation and differentiation during tumorigenesis and development of organs. miR-143 and miR-145 have key role in cellular differentiation and proliferation of smooth muscles and similar roles has been reported to their target genes, KRAS, MAP3K3 ERK5 and MAP4K4. Thus, this study aims to evaluate the expression of miR-143 and its targets genes ERK5 and KRAS and miR-145 and its targets MAP3K3 and MAP4K4 in BPH.

METHODS: The level of expression of miR-143 and 145 and their target genes were analyzed by qRT-PCR in frozen prostate tissue of four patients with BPH that were submitted to retropubic prostatectomy. The control group consisted by normal prostate tissue of 2 young patients, organ donors.

RESULTS: miR-145 showed underexpression and its target gene MAP4K4 was overexpressed in BPH compared to normal controls (Graphic 1). The miR-143 and its target genes KRAS and ERK5 were overexpressed in HPB compared with normal controls.

CONCLUSIONS: Underexpression of miR-145 can have a role in BPH, failing to control MAP4K4 that has been related to the development of BPH. A larger number of cases should be studied to confirm our initial findings.

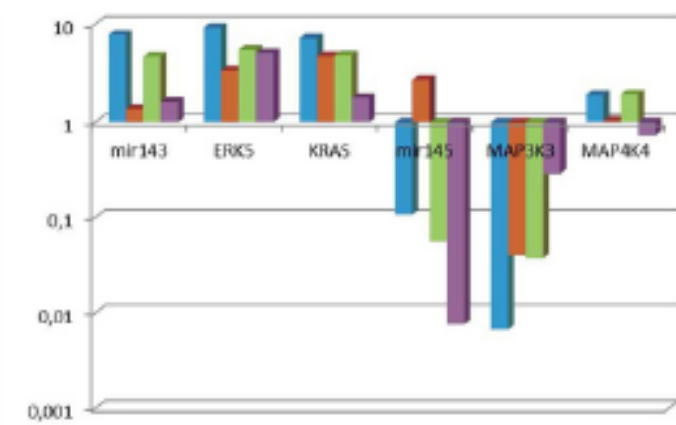

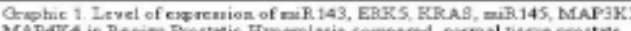

Source of Funding: FAPESP 
1202747

The role of micro RNA 143 and 145 and their target genes in the pathophysiology of Benign Prostatic Hyperplasia

Nayara Viana*, Sabrina Reis, Denis Reis, Iran Silva, Camila Piantino, Caio Moura, Nelson Dip, Luciana Timoszczuk, Miguel Srous Katia Leite, Alberto Antunes, São Paulo, Brazil

INTRODUCTION AND OBJECTIVES: Benign Prostatic Hyperplasia (BPH) is the most common benign tumor in me affecting millions of individuals around their sixties causing important urinary symptoms that impact negatively their quality of lif MicroRNA (miRNA) is a large class of small non-coding RNA molecules that act as regulators of gene expression. The miR143 ar 145 play a fundamental role in cellular differentiation and proliferation of smooth muscle. Therefore, this study aims to evaluate $n$ only the expression of miR143 and 145 but also their target genes ERK5, KRAS, MAP3K3 and MAP4K4 in the prostate of patien with $\mathrm{BPH}$

METHODS: We analyzed frozen prostate tissues from 44 patients with $\mathrm{BPH}$ that were submitted to transurethral resectic of the prostate. The control group consisted of normal prostate tissue taken from the central zone from two young patients, orge donors. The expression levels of miR143 and 145 and their target genes were analyzed through the qRT-PCR method.

RESULTS: miR143 and 145 were overexpressed in $62.5 \%$ and $73.8 \%$ of cases, respectively, in BPH compared to norm controls (Graphic 1). ERK5 presented underexpression in $59.45 \%$ of cases, demonstrating a possible control by miR143 The san was observed by MAP4K4 that was underexpressed in the majority of cases $(94.73 \%)$, demonstrating that it is probably regulate by miR145. On the contrary, KRAS and MAP3K3 gene were overexpressed in $79.48 \%$ and $61.53 \%$ of the cases, respectively. CONCLUSIONS: Overexpression presented by miR143 and 145 may be leading to an increase in stromal proliferation prostate tissue and inducing the contractile phenotype that has been demonstrated in $\mathrm{BPH}$. Together, our data demonstrate th these miRNA along with the action of its target genes may be involved in the pathogenesis of BPH, especially changing tr homeostasis of the fibro-muscular, controlling the proliferation and differentiation

Source of Funding: FAPESP \#10/50786-2

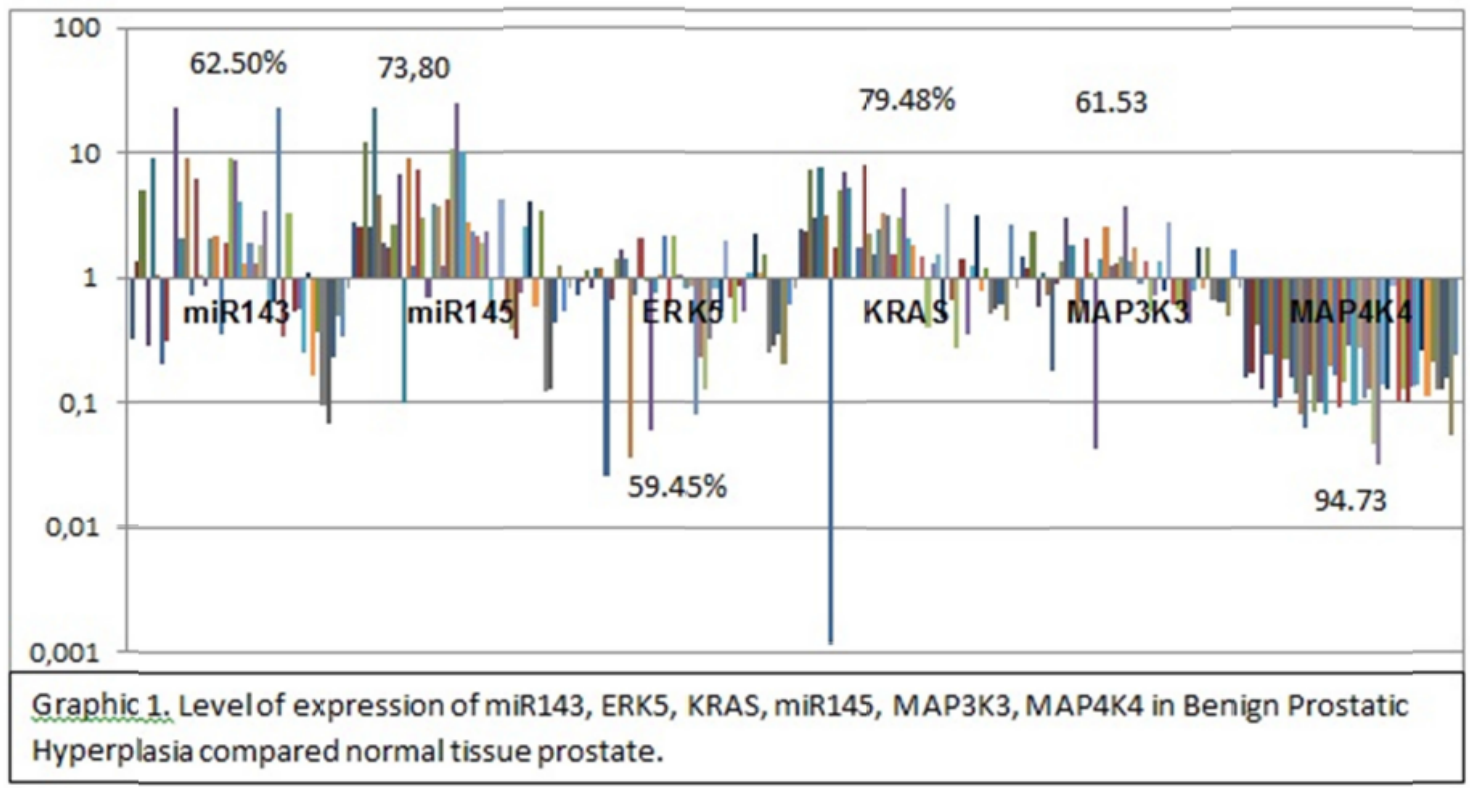




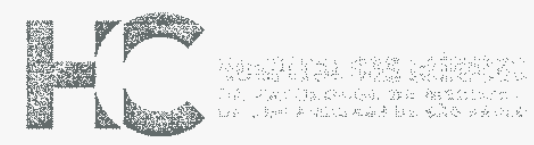

\section{APROVAÇÃO}

A Comissão de Ética para Análise de Projetos de Pesquisa CAPPesq da Diretoria Clínica do Hospital das Clínicas e da Faculdade de Medicina da Universidade de São Paulo, em sessão de 23/06/2010, APROVOU O Protocolo de Pesquisa n $n^{\circ}$ 0258/10, intitulado: "O PAPEL DOS MICRO RNA 143 E 145 E SEUS GENES ALVO NA FISIOPATOLOGIA DA HIPERPLASIA BENIGNA DA PRÓSTATA" apresentado pelo Departamento de CIRURGIA, inclusive 0 Termo de Consentimento Livre e Esclarecido.

Cabe ao pesquișador elaborar e apresentar à CAPPesq, os relatórios parciais e final sobre a pesquisa (Resolução do Conselho Nacional de Saúde n' 196, de 10/10/1996, inciso (X.2, letra "C").

Pesquisador (a) Responsável: Dr. Alberto Azoubel Antunes Pesquisador (a) Executante: Nayara Izabel Viana

CAPPesq, 24 de Junho de 2010
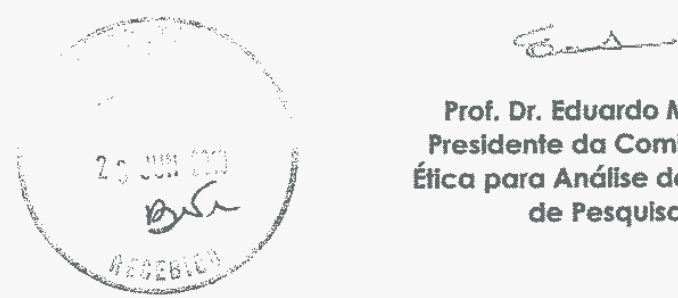

Prof. Dr. Eduardo Massad Presidente da Comissão de Ética para Análise de Projefos de Pesquisa 